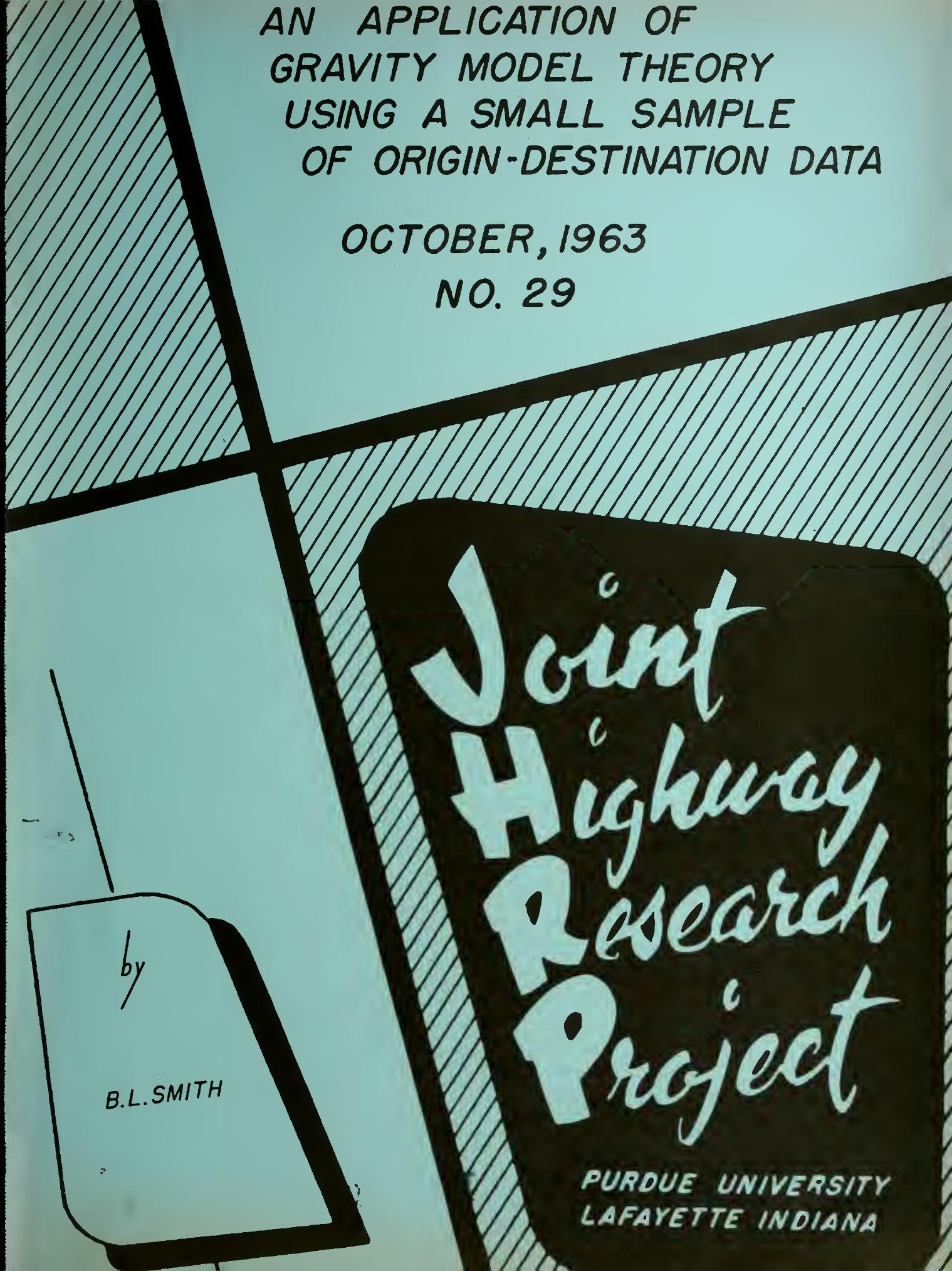


11 


\section{Informational Report}

\section{AN APPLICATION OF GRAVITY MODFL THEORY}

\section{USING A SMAIT SAMPLS OF ORIGINADESINATION DATA}

TO: $\quad$ K. B. Woods, Director

Joint Highway Research Project

October 31, 1963

FROM: H. I. Milchael, Assoclate Director

File: $3-2$

Joint Highway Research Project

A report entitled "An Application of Gravity Model Theory Using a Small Sarmle of Origin-Destination Data" by Bob L. Smith, Graduate Student at Purdue University is attached. The research reported by Mr. Smith was performed under the direction of Professor H. L。 Michael and financed by the Kansas State Highwey Commission and the Bureau of Public Roads. The researcin wes conducted on a Kansas city and primarily conducted by Mr. Smith in absentia. Mr. Smith also used the report as his thesis requirement for the $\mathrm{Ph} . \mathrm{D}$. degree from Purdue University。

The report is not a result of Project research but as is our custom is presented to the Board as information on an area of interest and concern to the Board. A paper prepared from this report has been submitted to the Highway Research Board.

The report is presented as information.

Respectfully submitted,

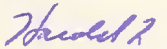

Harold L. Michael, Secretary

HIM:bc

Attachment

Copy:

F. I. Ashbaucher

J. Fo McIaughlin

J.R. Cooper

R. D. Miles

W. I. Doleh

R. E。 MIIIs

W. H. Coetz

B., B. Scott

F。 F。 Havey

J. V. Smythe

F. S. Hill

E. J. Yoder

G. A. Leonards 
Informational Report

AN APPIICATION OF GRAVIIY MODEL TEEORY

USING A SMAIT SAAFIE OF OFIGINODESTINATIOII DATA

by

Bob I. Smith

Gradisite Student

School of Civi. Ingineering

Purdue Univerulty

File: 3-

Prepared as Part of an Investigation

Conducted by

Fofineering Experimest Station

Kansa.s State Univirsity

in cooperation "rith

Kanses Highway Camission

and

Bureau of Publi.c Roads

U. S. Department of Commerce

and

School of Civil Fingineering

Purdue University

Lapayette, Indiana

October 31,1963 


\section{ACKNOWLEDGMENTS}

The author wishes to express his sincere appreciation to Professor Harold L. Michael, Associate Director of the Joint Highway Research Project for his counsel, and especially for his encouragement both during the period in which this research project was being formulated and in the course of the research. He also expresses his appreciation for Professor Michael's critical review of the manuscript.

The author wishes to thank the National Science Foundation and Kansas State University for making possible his pre-doctoral studies prior to his undertaking of this research. A National Science Faculty Fellowship and a sabbatical leave provided the opportunity for that year of study.

This research was financed by Highway Planning Survey Federal Highway funds under the auspices of the Kansas State Highway Commission and the U. S. Bureau of Public Roads. The author is most appreciative of the opportunity thus afforded to carry out this research. 
Digitized by the Internet Archive in 2011 with funding from

LYRASIS members and Sloan Foundation; Indiana Department of Transportation 


\section{TABLE OF CONTENTS}

LIST OF TABLES.

Page

LIST OF ILLUSTRATIONS.

LIST OF ILIUSTRATIONS .

ABSTRACT

INTRODUCTION .

Purpose . . . . . . . . . . . . . .

Scope.

Gravity Model Theory and Use.

xii

STUDY PROCEDURE

Preparation of O-D Survey Data for Use in the Research. .

Classification of Trips by Purpose............

Additional Data Obtained............ 26

Selection of Zones for use in the Reduced Sample Study . . 27

The Development of Equations for Estimating Zonal Pro-. . ductions. . . . . . . . . . . . . . . 29

Selection of Reduced Samples . . . . . . . . 34

The Development of Equations for Estimating Zonal

Attractions . . . . . . . . . . . 44

The Development of Travel Time Factors . . . . . . 49

ANALYSIS OF RESULTS .................. 64

Estimates of Trip Production and Attraction . . . . . . . 64

Gravity Model Distribution . . . . . . . . . . . 86

Screenline Comparison . . . . . . . . . . 86

Trip Length Comparison . . . . . . . . . 101

Comparison of District to District Movements . . . . 120

CONCLUSIONS

- recommendations for further Research . . . . . 134

LIST OF REFERENCES . . . . . . . . . . 135

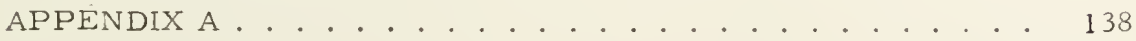

APPENDIX B................................ 145

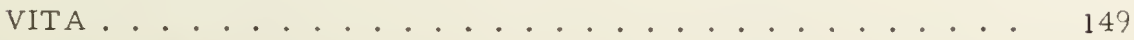




\section{LIST OF TABLES}

Table

Page

1. Cities of Kansas Having Population Over 10,000....

2. Auto-Driver Trips by Residents of Internal Area, Showing O-D Survey Recorded Purpose of Trip . . . .

3. Per cent Auto Driver Trips by Residents of Internal

Area, Showing O-D Survey Recorded Purpose of Trip....................

4. Auto Driver Trips - by Purpose of Trip (Initial) .....

5. Auto Driver Trips - by Purpose of Trip..........

6. Zonal Characteristics............. 30

7. Reduced Sample Selection in the 14 Selected Zones...

8. Zonal Characteristics used for Trip Production Estimates: Data from O-D Full Sample in the 14 Selected Zones .................

9. Zonal Characteristics used for Trip Production Estimates: Data from O-D Reduced Sample in 14 Selected Zones.

10. Trip Attractions and Non-Home Productions from

O-D Full Sample Data from the 14 Selected Zones.. . 40

11. Trip Attractions and Non-Home Productions from the

O-D Reduced Sample Data from the 14 Selected Zones. . 42

12. Final Terminal Times by Zone and Trip Purpose . . . 52

13. Cedar Rapids (Iowa) Travel Time Factors . . . . . . 55

14. Travel Time Factors by Trip Purpose . . . . . . . . 60

15. Estimating Equations for Trip Production from Multiple Regression Analyses . . . . . . . . . . 
List of Tables (Continued)

Table

16. Estimating Equations for Trip Attraction from

Multiple Regression Analyses . . . . . . . . .

17. Coefficients of Correlation and Determination from Regression Analysis . . . . . . . . . . .

18. RMS Errors of Estimating Equations .........

19. Comparison of Home-Work Trip Production and Attraction-Values from O-D and Estimating Equations -

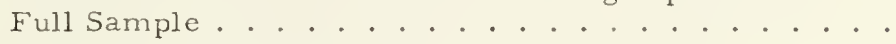

20. Comparison of Home-Work Trip Production and Attraction-Values from O-D and Estimating Equations Reduced Sample... . . . . . . . . . . .

21. Comparison of Home-Other Trip Production and Attraction-Values from O-D and Estimating Equations - Full Sample... . . . . . . .

22. Comparison of Home-Other Trip Production and Attraction-Values from $O-D$ and Estimating Equations - Reduced Sample . . . . . . . . . .

23. Comparison of Non-Home Trip Production and Attraction-Values from O-D and Estimating Equations - Full Sample .............

24. Comparison of Non-Home Trip Production and At traction-Values from O-D and Estimating Equations - Reduced Sample . . . . . . . . .

25. Comparison of Non-Home Trip Production and Attraction-Values from O-D and Estimating Equations - Reduced Sample (Adjusted) . . . . . .

26. Comparison of Screenline Crossings of All Trips Using $\mathrm{O}-\mathrm{D}$ and Model Data ...........

27. Comparison of Screenline Crossings of Home-Work Trips Using O-D and Model Data 
List of Tables (Continued)

Table

28. Comparison of Screenline Crossings of HomeOther Trips Using $\mathrm{O}-\mathrm{D}$ and Model Data . . . . .

29. Comparison of Screenline Crossings of NonHome Trips Using O-D Model Data........

30. Comparison of Vehicle Hours of Travel and Average Trip Length from O-D and Model Data Using Travel Time Factors from the Full Sample O-D

Data...................

31. Comparison of Vehicle Hours of Travel and Average Trip Length from O-D and Model Data Using Travel Time Factors from the 14 Selected Zones Reduced Sample O-D Data..........

32. Comparison of Vehicle Miles of Travel and Average Trip Length from O-D and Model Data Using Travel Time Factors from the Full Sample O-D Data...............

33. Comparison of Vehicle Miles of Travel and Average Trip Length from O-D and Model Data Using Travel Time Factors from the 14 Selected Zones Reduced Sample O-D Data.........

34. Analysis of District to District Movements Home-Work Trips, Full Sample, Complete O-D Productions-Attractions, Travel Time Factors from Reduced Sample O-D Data - . . . - . -

35. Analysis of District to District Movements Home - Other Trips, Full Sample, Complete O-D Productions-Attractions, Travel Time Factors from Reduced Sample O-D Data . . . . . . . .

36. Analysis of District to District Movements Non - Home Trips, Full Sample, Complete O-D Productions-Attractions, Travel Time Factors from Reduced Sample O-D Data . . . . . . . . . 


\section{List of Tables (Concluded)}

Table

Page

37. Analysis of District to District Movements All Trips, Full Sample, Complete O-D Productions-Attractions, Travel Time Factors from Reduced Sample O-D Data .........

38. Analysis of District to District Movements Home - Work Trips, Full Sample, Regression Productions-Attractions, Travel Time Factors from Reduced Sample O-D Data.........

39. Analysis of District to District Movements Home - Other Trips, Full Sample, Regression Productions-Attractions, Travel Time Factors from Reduced Sample O-D Data.........

40. Analysis of District to District Movements Non - Home Trips, Full Sample, Regression Productions-Attractions, Travel Time Factors from Reduced Sample O-D Data..........

41. Analysis of District to District Movements All Trips, Full Sample, Regression ProductionsAttractions, Travel Time Factors from Reduced Sample O-D Data ..............

42. Analysis of District to District Movements All Trips, Full Sample, Complete O-D Productions-Attractions, Travel Time Factors from Full Sample O-D Data .............

43. Analysis of District to District Movements All Trips, Fill Sample, Regression ProductionsAttractions, Travel Time Factors from Full Sample O-D Data . . . . . . . . . . . . 


\section{LIST OF ILLUSTRATIONS}

Figure

Page

1. Hutchinson, Kansas Metropolitan Area Zone Map Showing Screen Lines and Selected Zones for Study................. 6

2a. Trips Made by One Tripmaker Whose Zone of Residence is Zone 1 ........... 10

2b. Trips Made by One Tripmaker Whose Zone of Residence is Zone 3............. 10

3. Schematic Diagram of the Process of Determining Zonal Trip Productions and Attractions.. .

4. Relation of Per cent Root-Mean-Square Error and Volume for Various Dwelling Unit Sample Rates . .

5. Comparison of Trip Length Frequency Using O-D

Data - Home - Work Trips ...........

6. Comparison of Trip Length Frequency Using O-D Data - Home - Other Trips . . . . . . . . .

7. Comparison of Trip Length Frequency Using O-D

Data - Non- Home Trips . . . . . . . . . .

8. Comparison of Trip Length Frequency Using O-D and Model Data - Home - Work Trips . . . . . .

9. Comparison of Trip Length Frequency Using O-D and Model Data - Home - Other Trips . . . . . .

10. Comparison of Trip Length Frequency Using O-D and Model Data - Non - Home Trips... . . . .

11. Comparison of Travel Time Factors - Full Sample vs. Reduced Sample O-D Data - Home - Work Trips... . . . . . . . . . . . . . 
List of Illustrations (Continued)

Figure

Page

12. Comparison of Travel Time Factors - Full

Sample vs. Reduced Sample O-D Data -

Home - Other Trips . . . . . . . . . . . .

13. Comparison of Travel Time Factors - Full

Sample vs. Reduced Sample O-D Data -

None - Home Trips... . . . . . . . . . .

14. Comparison of Home- Work Trips Produced

(Equation No. 1) . . . . . . . . . . . .

15. Comparison of Home - Work Trips Produced

(Equation No. 2)..................

16. Comparison of Home - Other Trips Produced

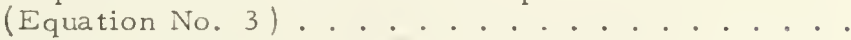

17. Comparison of Home - Other Trips Produced

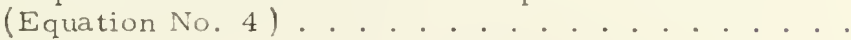

18. Comparison of Non-Home Trips Produced

(Equation No. 5) . . . . . . . . . . .

19. Comparison of Non-Home Trips Produced

(Equation No.6)................

20. Comparison of Home - Work Trips Attracted

(Equation No. 7) ................

21. Comparison of Home - Work Trips Attracted

(Equation No. 8) . . . . . . . . . . .

22. Comparison of Home - Other Trips Attracted (Equation No. 9) ...............

23. Comparison of Home- - Other Trips Attracted

(Equation No. 10) ..............

24. Comparison of Non - Home Trips Attracted (Equation No. 11) ............... 
List of Illustrations (Con tinued)

Figure

Page

25: Comparison of Non - Home Trïps Attracted

(Equation No. 12) ............

26. Comparison of Trip Length Frequency Using O-D and Model Data - Home - Work Trips Combination 1 Parameters......... 106

27. Comparison of Trip Length Frequency Using O-D and Model Data - Home - Other Trips Combination 1 Parameters ...........

28. Comparison of Trip Length Frequency Using O-D and Model Data - Non - Home Trips Combination I Parameters . . . . . . . . .

29. Comparison of Trip Length Frequency Using O-D and Model Data - Home - Work Trips Combination 2 Parameters ...........

30. Comparison of Trip Length Frequency Using O-D and Model Data - Home - Other Trips Combination 2 Parameters . . . . . . . .

31. Comparison of Trip Length Frequency Using O-D and Model Data - None - Home Trips Combination 2 Parameters ...........

32. Comparison of Trip Length Frequency Using O-D and Model Data - Home - Work Trips Combination 3 Parameters ..........

33. Comparison of Trip Length Frequency Using O-D and Model Data - Home - Other Trips Combination 3 Parameters ...........

34. Comparison of Trip Length Frequency Using O-D and Model Data - Non - Home Trips Combination 3 Parameters 


\section{List of Illustrations (Concluded)}

Figure

Page

35. Comparison of Trip Length Frequency Using O-D

and Model Data - Home - Work Trips -

Combination 4 Parameters........... 115

36. Comparison of Trip Length Frequency Using O-D

and Model Data - Home - Other Trips -

Combination 4 Parameters . . . . . . . . . I 16

37. Comparison of Trip Length Frequency Using O-D

and Model Data - Non - Home Trips -

Combination 4 Parameters . . . . . . . . . 


\section{ABSTRACT}

Smith, Bob L., Ph. D., Purdue University, January 1964. An Application of Gravity Model Theory Using a Small Sample of Origin-destination Data. Major Professor: Harold L. Michael.

This thesis reports the results of a study concerned with an application of the gravity model in which the model parameters - trip production, trip attraction and travel time factors - - were estimated using data obtained from a small sample of home interviews taken in a sample of origin-destination (O-D) survey zones.

A gravity model was calibrated using the estimations of trip productions and attractions obtained from the small sample of O-D interviews. An additional model was calibrated using the productions and attractions obtained from the comprehensive O-D survey. The resulting distributions were compared with the distributions obtained from the comprehensive survey.

In the sample study, the information obtained from interviews from 402 dwelling units in 14 selected zones in the survey area was utilized. The comprehensive O-D study consisted of 2,528 interviews obtained from a 20 per cent sample of dwelling units from all 83 zones in the survey area. The comprehensive survey was conducted in 1959 in Hutchinson, Kansas which had a population of approximately 38,000 persons. The study was limited to the consider- 
ation of auto-driver trips in which each trip had both its origin and destination within the survey area.

The auto-driver trips were classified according to trip purpose and the three trip purposes of home-work, home-other, and non-home were studied in detail.

The study was concerned with "present day" traffic rather than with the estimation of future traffic; however the data used in the development of estimating equations for trip attractions and trip productions were those which one could expect to be obtained quickly and economically, and that one could expect to estimate reasonably well for the future.

Current zonal trip productions and attractions were adequately estimated from the mathematical models developed from the small sample of home interviews. Best estimates resulted for home-based trip productions, but estimates of non-home-based trip productions and all trip attractions appeared to be adequate for planning purposes.

Travel time factors for the distribution of trips were satisfactorily estimated by calibrating the gravity model with trip length frequency data developed from the small sample of home interviews.

The gravity model using trip productions and travel time factors developed from the small sample of home interviews distributed trips among all zones to give an adequate reproduction, for planning purposes, ${ }_{z}$ of the trip distribution obtained in the comprehensive O-D study. 


\section{INTRODUCTION}

Since the end of World War II, the increase in size of urban areas and the increase in automobile ownership have created new and involved transportation problems. Organizations such as the Bureau of Public Roads, state highway departments and other federal, state and municipal agencies are vitally concerned with the making of decisions which relate to both when and where to construct new roads and streets or to improve existing ones.

In order to carry out the planning of solutions to a particular urban transportation problem, the agency or persons involved must have available factual data which describe the problem as it exists and from which estimates may be made of the problem as it may exist in the future. The gathering and the analysis of such data is called a transportation study. A large number of such studies have been made in the last ten years and concerted efforts to develop more meaningful transportation studies have resulted in general agreement that urban traffic patterns (1)* are a function of:

1. The type and extent of the transportation facilities t available in an area.

2. The pattern of land use in an area, including the location and intensity of use.

3. The various social and economic characteristics of the people who make trips.

* Numbers in parentheses refer to items in the list of references. 
As a result there has been made a significant effort to develop a transportation planning process which utilizes these interrelationships in providing quantitative information on the travel demands created by alternate land use patterns and transportation systems in any urban area. Such information can then be used by various agencies to make the decisions about when and where to make improvements in transportation networks to satisfy present and future travel demands, and to promote desirable land development patterns.

The planning process must, then, be capable of estimating within limits of acceptable accuracy, the zonal trip interchanges for the alternate land use patterns and transportations systems one might reasonably expect to develop in an area. The problem then becomes one of developing such a process. As one would expect, the information obtained from home interview origin-destination surveys coupled with information on the existing land use configuration and transportation system gives an adequate picture of the existing travel patterns in an area. However, it is the future travel demands with which we are most interested, and the present-day data must in someway be extrapolated to the future.

Studies of travel habits have led to the development of mathematical formulas or "traffic models" which can satisfactorily reproduce zonal trip interchange estimates from comprehensive home interview traffic studies. If one can estimate, within acceptable limits of accuracy, the present-day zonal interchanges, and as these interchanges are dependent upon measurable characteristics of the urban area it follows, that if one can estimate the future urban 
characteristics such as intensity and type of land use, the distribution of job opportunities, and the economic status of the residents, one should be able to estimate the zonal interchanges of the future. This is subject, of course, to the possibility that, for a given set of identical circumstances for the present and the future, higher or lower trip generation rates may result because of a change in the amount of travel per vehicle. Several formulations of traffic models have been developed for the estimation of future interchanges, particularly in large metropolitan areas, but much additional research is reeded to evaluate and verify the various models in cities of all sizes.

The mathematical traffic model offers to those responsible for making the decisions concerning the development of the transportation system estimates of likely consequences in terms of traffic patterns for various alternative land use configurations and transportation systems.

There are a number of different traffic models currently being utilized in transportation studies but the most widely used model to date is the so-called "gravity model." This model is based upon the adaptation of Newton's Law of gravity to the movements of human beings. Newton's Law states that the gravitational force exerted between two bodies in space is in direct proportion to the masses of the two bodies and inversely proportional to the square of the distance between the bodies.

A number of persons over the years have used Newton's Law as applied to human activities with varying degrees of success. In the middle $1800^{\prime} \mathrm{s}, \mathrm{H}$. C. Carey (2) theorized that the attraction 
force between two large population masses followed Newton's Law; G. K. Zipf (3), W. J. Reilly (4), and H. J. Casey (5) were among others that attempted to apply Newton's Law to human activities. In 1955, Alan Voorhees developed a gravity model theory of traffic movement in which he used the principle of Newton's Law (6).

In order to apply the gravity model theory to a given city. it generally is considered necessary to conduct, as a minimum, a comprehensive origin-destination (O-D) survey and to "calibrate" or adjust the model to reproduce, at an acceptable level, the trip distributions found in the $O-D$ survey. The model is then used to distribute trips with various configurations of land use and transportation alternatives that one would logically expect to develop in the future.

The survey methods used to gather $\mathrm{O}-\mathrm{D}$ data on present-day travel are both expensive and time consuming. Certain Iowá studies ( 7 ) (13) indicated quite graphically the savings in time and money made possible by the utilization of the Gravity Model, and also explored the feasibility of applying the gravity model to cities with a population as small as $34.7 n n$ persons. In nearly all of the previous uses of this model

- very large metropolitan areas were studied ( 1?).

\section{Purpose}

This research was concerned with thè use of the gravity model in a small city and was conducted to study the feasibility of using a sinall sample of home interviews taken in a sample of O-D zones to estimate the gravity model parameters, trip production, trip attrac- 
tion and travel time factors. A gravity model was calibrated using the estimations of trip productions and attractions obtained from the small sample of $\mathrm{O}-\mathrm{D}$ interviews. An additional model was calibrated using the productions and attractions obtained from the comprehensive home-interview $\mathrm{O}-\mathrm{D}$ survey. The resulting distributions were compared with the distribution obtained from the comprehensive survey.

In the sample study, the information obtained from interviews from 402 dwelling units in 14 selected zones was utilized. The comprehensive O-D study consisted of 2,528 interviews obtained from a 20 per cent sample of dwelling units from all 83 zones in the survey area.

\section{Scope}

The study was limited to the consideration of auto-driver trips which were internal in nature. That is, each trip had both its origin and destination within the survey area. The survey area is shown in Figure 1.

The auto-driver trips were classified according to trip purpose. The three trip purposes of home-work, home-other and non-home-based trips were studied in detail.

The study was concerned with "present day" traffic rather than with the estimation of future traffic; however, the data used in the development of estimating equations for attractions and productions were those which one could expect to be obtained quickly and economically, and that one could expect to estimate reasonably well for the future. 


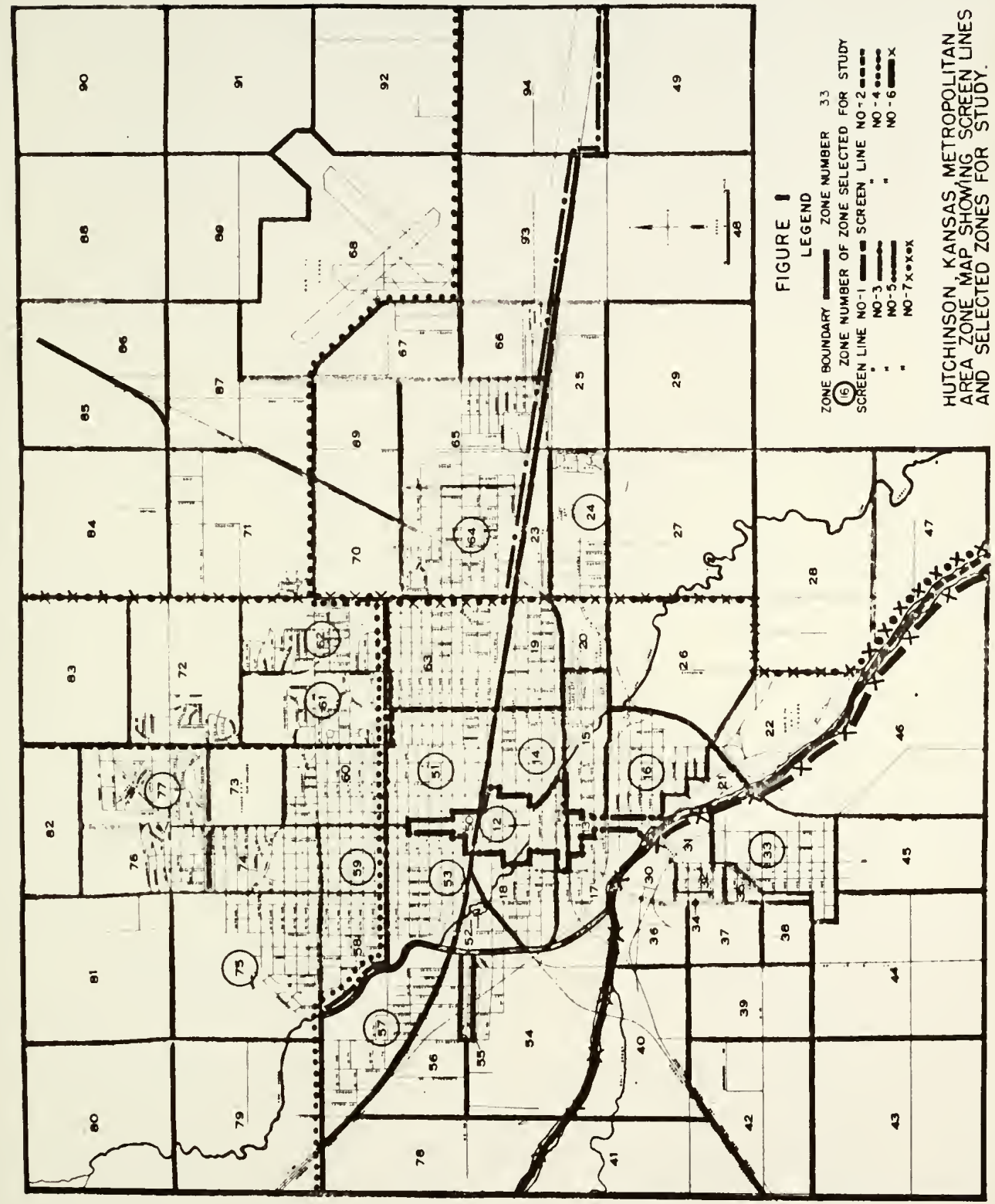




\section{Gravity Model Theory and Use}

The gravity model theory as proposed by Voorhees stated that the trip interchange between zones is directly proportional to the relative attraction for trips of each of the zones and inversely proportional to some function of the spatial separation between zones.

Stated mathematically, the gravity model formulation as used in its earlier applications, is shown below.

$$
T_{i-j}=P_{i}\left[\frac{\frac{A_{j}}{\left(d_{i-j}\right)^{b}}}{\frac{A_{i}}{\left(d_{i-i}\right)} b+\frac{A_{j}}{\left(d_{i-j}\right)^{b}}+\cdots \frac{A_{n}}{\left(d_{i-n}\right)^{b}}}\right]
$$

Where $\mathrm{T}_{\mathrm{i}-\mathrm{j}}=$ Trips produced by zone $\mathrm{i}$ and attracted to zone $\mathrm{j}$

$\mathrm{P}_{\mathrm{i}} \quad=$ Trip produced by zone $\mathrm{i}$

$\mathrm{A}_{\mathrm{j}} \quad=$ Trips attracted by zone $\mathrm{j}$

$d_{i-j}=$ The spatial separation between zones $i$ and $j$, and generally expressed as total travel time between zones $i$ and $j$

b = An empirically determined exponent which expresses the average areawide effect of spatial separation between zones on the amount of trip interchange.

Early research by Voorhees and others indicated that the exponent, b, varied between 0.6 and 0.8 for work trips in areas of different population size (7). Davidson (8) found exponents of 3.5 and 5.0 most suitable for work trips and non-work trips, respectively, and the differences among exponents developed by him and those developed by Voorhees and others were explained to some extent by 
differences in the manner of measuring time and distance between zones. A number of studies have indicated the need for a variable exponent and Davidson (8) found that the best exponent for near zones was different from the best exponent for distant zones.

In response to the studies indicating a need for a variable exponent and other refinements, the form of the gravity model formula was changed to the following which was used in this study:

$$
T_{i-j}=\frac{P_{i} A_{j} F_{i-j} K_{i-j}}{\sum_{x=1}^{n} A_{x} F_{i-x} K_{i-x}}
$$

in which the distribution is generally handled on a basis of various trip purposes and where:

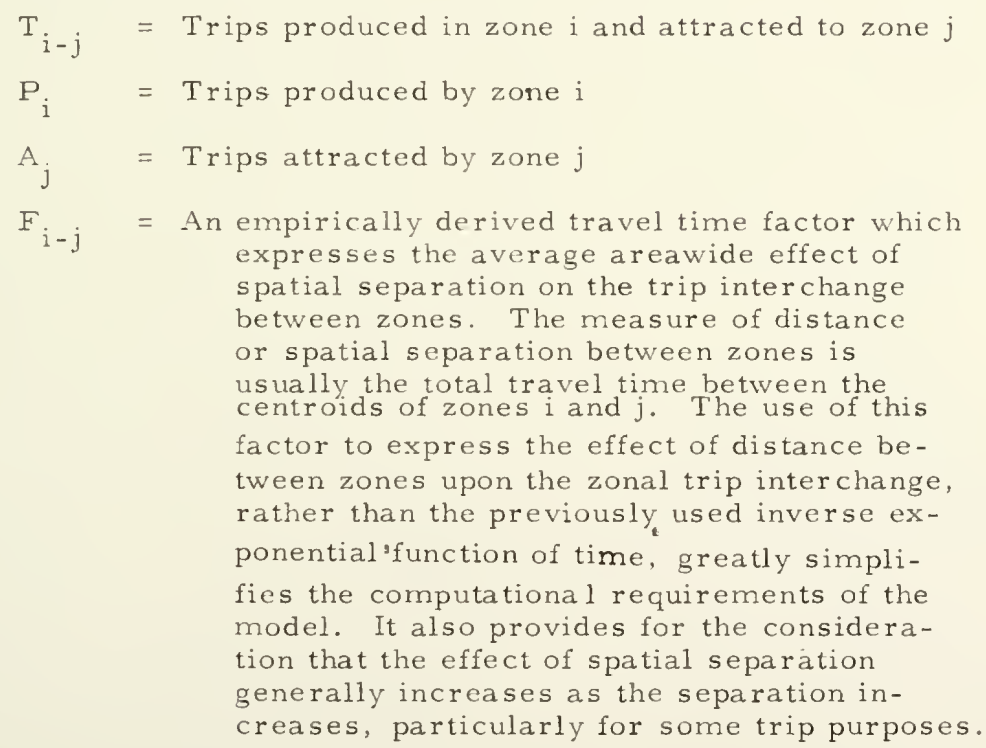




$$
\begin{aligned}
\mathrm{K}_{\mathrm{i}-\mathrm{j}}= & \text { A specific zone-to-zone adjustment factor } \\
& \text { to allow for the incorporation of the effect } \\
& \text { on travel patterns of defined social or } \\
& \text { economic linkages not otherwise accounted } \\
& \text { for in the gravity model formulation. } \\
\mathrm{n} \quad= & \text { Total number of zones. }
\end{aligned}
$$

In dealing with the gravity model, confusion often exists among the terms productions, attractions, origins, and destinations.

With the exception of trips classified as non-home-based, the number of trips produced refers to the number of trips originating in and returning to a given zone; the number of trips attracted refers to the number of trips arriving at and departing from a given zone. The gravity model, in the determination of $\mathrm{T}_{i-j}$, deals with trip interchange between zones and such interchanges do not imply the direction of movement. The trip interchange between zones is often referred to as "non-directional" or "two-way" trips as opposed to directional trips or trips which start in zone i and end in zone j. Some models use the one-way trip and deal with origins and destinations. As an illustration of the differences between trip productions and attractions consider the following example:

Figure 2a schematically represents trips made by occupants of a given dwelling unit of Zone 1, while Figure $2 \mathrm{~b}$ represents trips made by a resident of Zone 3. The "tail" of the arrow (a trip) represents an origin, while the "head" of the arrow represents a destination.

The trips illustrated in each figure will be separated into two. categories, the "home-based" and the "non-home-based" trips. Any trip in which the home is one end of the trip is classified as a homebased trip. The home-based trip may be further classified with 


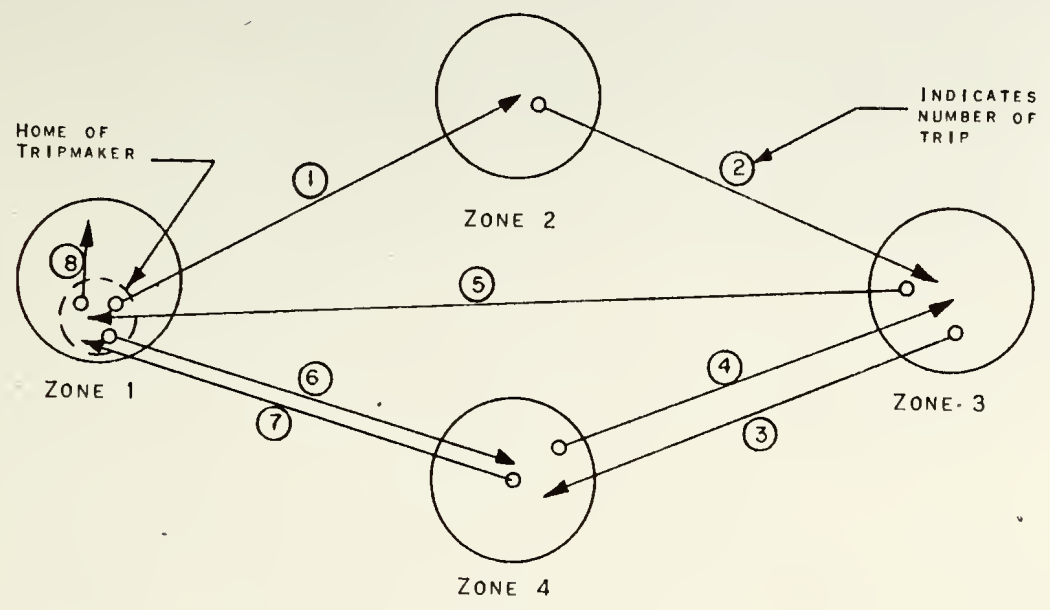

FIGURE 2a

TRIPS MAOE GY ONE TRIPMAKER WHOSE

ZONE OF RESIDENCE IS ZONE 1

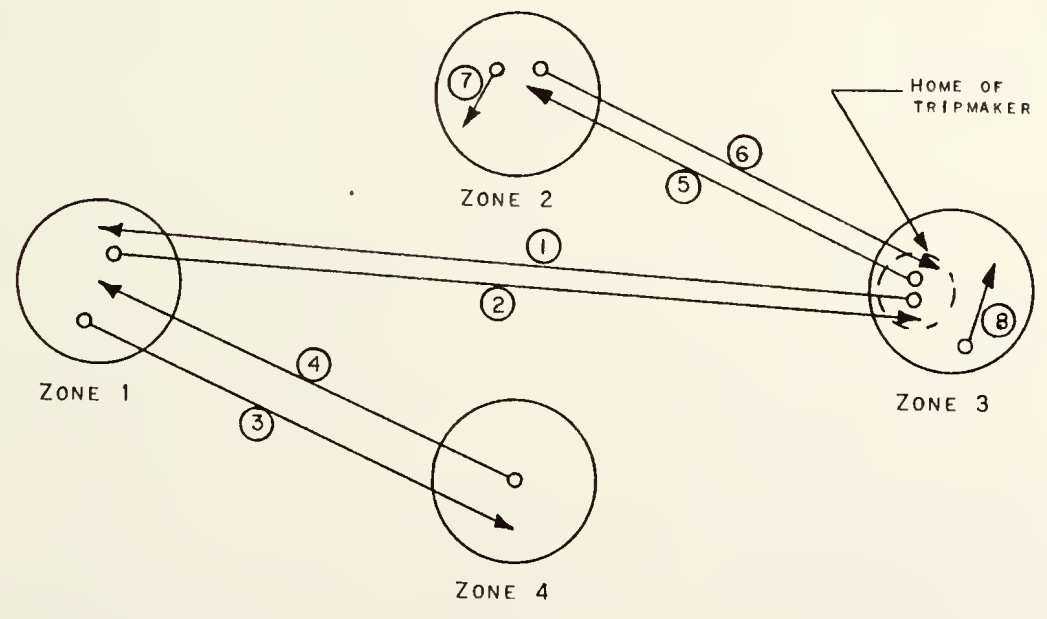

F IGURE 2b

TRIPS MADE BY ONE TRIPMAKER WHOSE ZONE OF RESIDENCE IS ZONE 3 
regard to trip purpose such as work, eat meal, social, medicaldental, school, etc. Any trip in which the home is neither end of trip is classified as a non-home-based trip. In Figure 2a, trips 1, 5, 6, 7 and 8 are home-based trips while in Figure 2b trips 1, 2, 5 and 6 are home-based trips.

Trip 8 in Figure 2a, and trips 7 and 8 in Figure $2 \mathrm{~b}$ are intrazonal trips since both ends of the trip remain within a single zone. All other trips are interzonal trips.

In Figure 2a, Zone 1, the zone of residence of the trip maker "produces" 5 home-based trips (trip ends), and in Figure 2b, Zone 3, the zone of residence of the trip maker "produces" 4 home-based trips (trip ends). Note that in Figure 2a the origin of trip 1, the destination of trip 5, the origin of trip 6, the destination of trip 7 , and the origin of trip 8 are trip "productions" and similarly, in Figure 2b, the origin of trip 1, the destination of trip 2, the origin of trip 5, and the destination of trip 6 are termed trip "productions." Note that in either Figure $2 a$ or $2 b$ that only those zones in which the trip maker resided were producers of home-based trips.

It follows then that for any zone to be producer of home-based trip ends there must be persons residing in that zone making trips that have one end at home.

Any end of a home-based trip which is not a "production" is said to be an "attraction". The home-based trip attractions are" distributed as follows: 

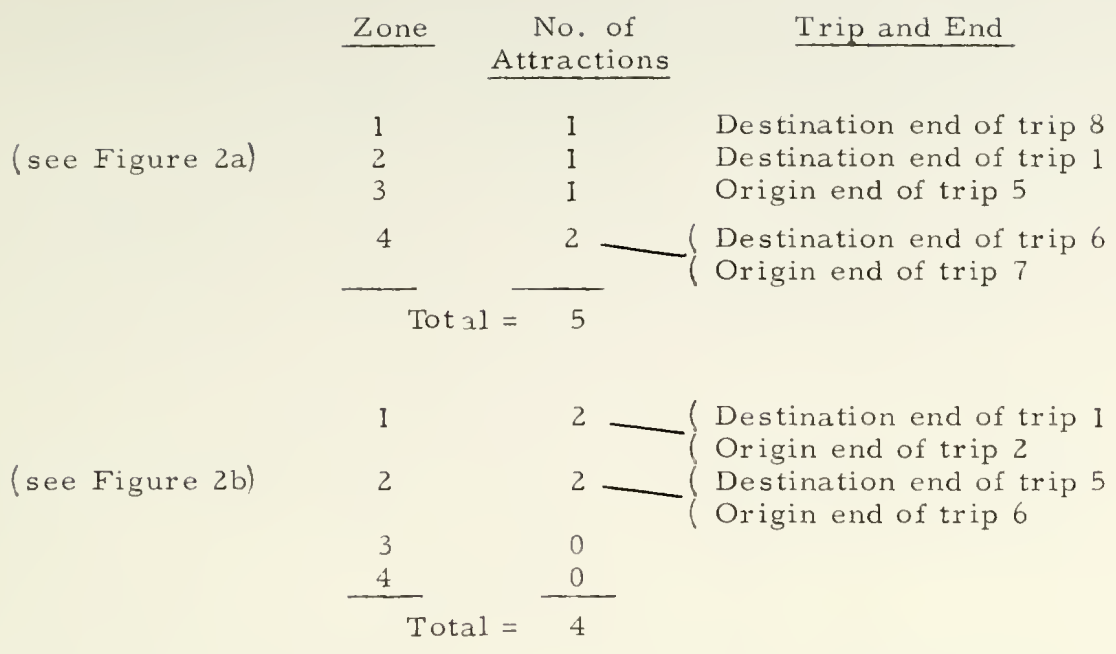

Consider the non-home based trips. In Figure $2 \mathrm{a}$, the nonhome-based trips are trips 2, 3 and 4, and in Figure 2b, they are trips 3, 4, 7 and 8. For non-home-based trips, the production end of a trip is its origin end and the attraction end is its destination.

The non-home-based trip production is distributed as follows:

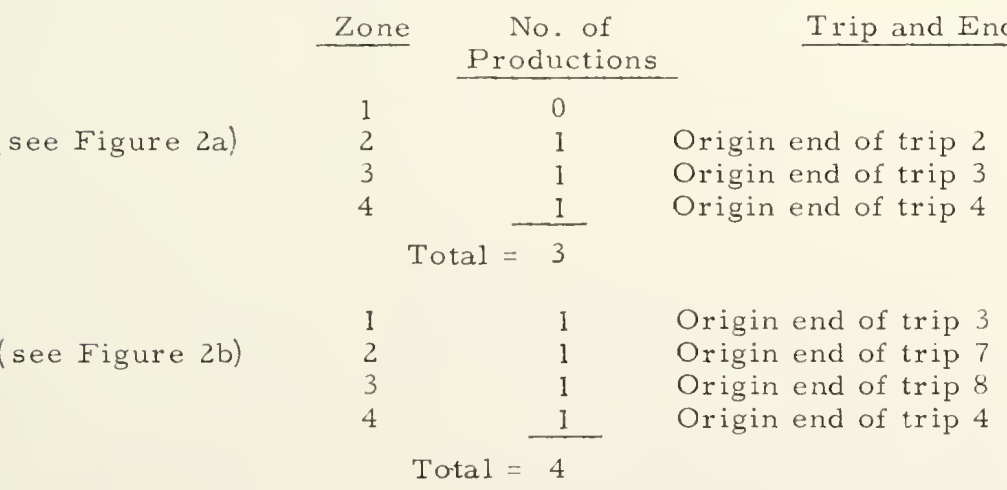


The non-home-based attractions are distributed as follows:

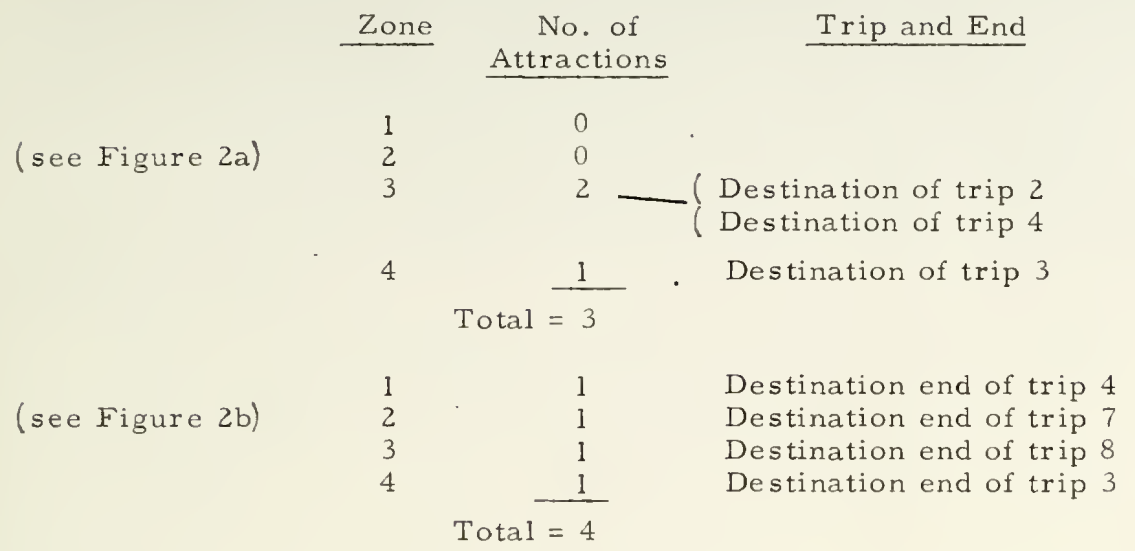

Note that there are always as many productions as attractions on a total study area basis since each trip has two ends.

If one would superimpose Figure $2 \mathrm{a}$ upon Figure $2 \mathrm{~b}$, the gross effect would be that of having considered trips by persons residing in both Zones 1 and 3 . If all internal trips by all residents of the zones were recorded, total trip productions and attractions could be determined. If one would interview each resident of Zone 1 and determine the trips produced and attracted to each of the four zones for both home-based and non-home-based trips, one would have the following - information:

(a) The total number of trip productions that would be said to be produced by Zone 1. (This number would correspond to $P_{i}$ in the gravity model formula.)

(b) The number of home-based trip attractions in each zone would correspond only to the disdistribution of the attraction ends of trips produced by the residents of Zone 1 .

The non-home-based attractions and productions, likewise, would correspond only to the distribution of the non-home-based trips "made" by the residents of Zone 1 . 
It follows, then, that to obtain the total number of home-based attractions, or non-home-based productions or attractions in a given zone the universe of all the population of all zones must be interviewed or sampled while the total number of home-based productions of a given zone can be obtained by interviewing or sampling from that particular zone.

Figure 3 shows a schematic diagram of the process of determining zonal trip productions and attractions. 

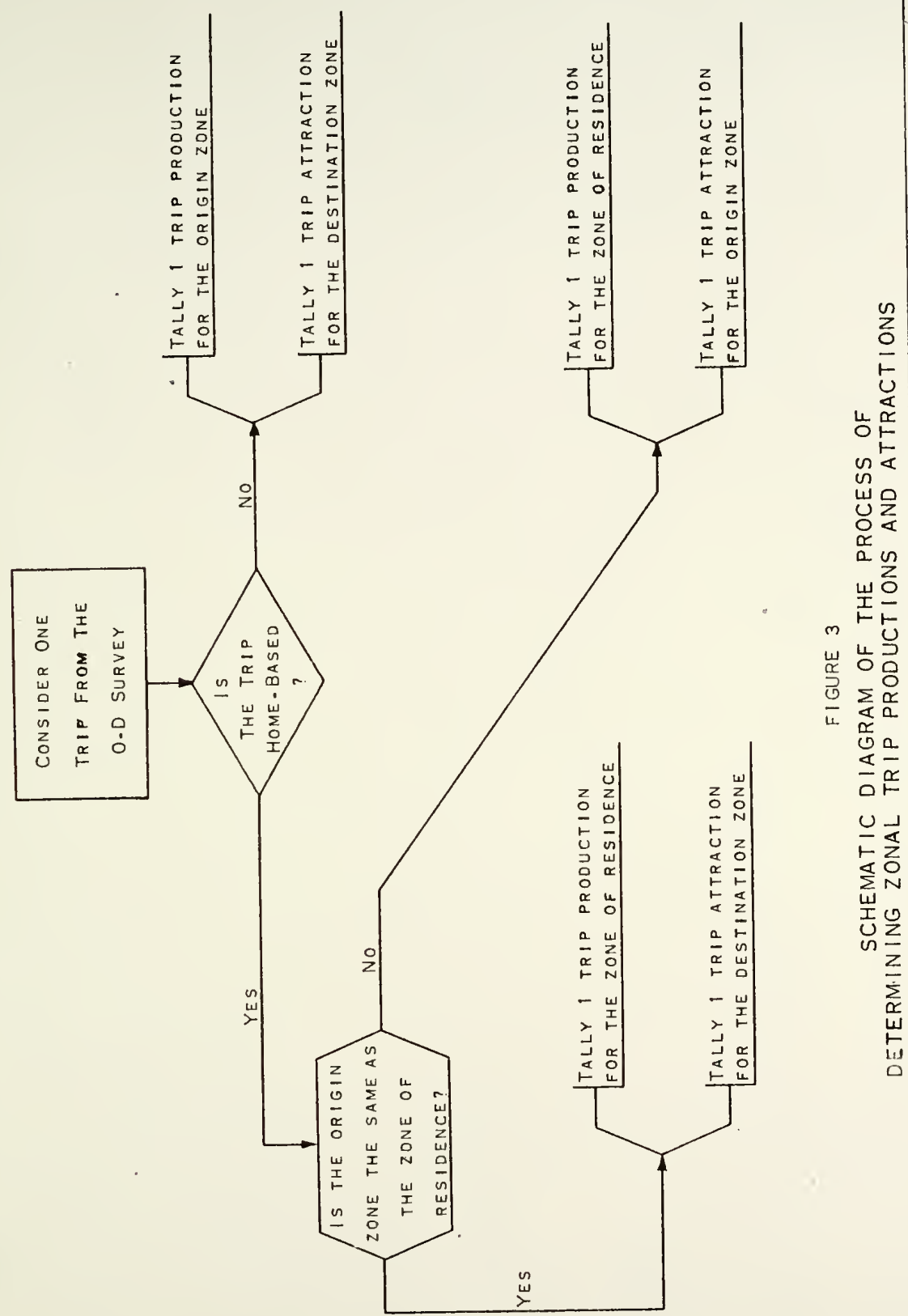


\section{STUDY PROCEDURE}

In order to carry out the objectives of the research, the metropolitan area of Hutchinson, Kansas was chosen for the study. The City, in 1961, had a population of 37,873 while the metropolitan area had a population of approximately 41,000 persons. At the initiation of this project this was the only "smaller" city in Kansas in which both an internal origin-destination survey as well as a land use study had been made. The Pittsburg, Kansas Transportation Study was completed in the summer of 1903. Origin-destination and sorre land use data were available for Topeka, Wichita and Kansas City, Kansas. These were the three largest metropolitan areas in Kansas and were not typical in size of "smaller" Kansas Cities. Table l indicates all cities in Kansas with a population over 10,000. There were 24 cities, outside of metropolitan areas, with a population between 10,000 and 50,000 , and only 3 cities with a population over 50,000. It was believed that the results of the study, if aimed at such smaller cities, would be of greatest value in Kansas since the smaller cities so outnumber the larger metropolitan areas.

In 1959, the Kansas State Highway Planning Department, in cooperation with the Bureau of Public Roads and the City of Hutchinson, conducted a comprehensive home interview O-D survey and a complete land use study in the Hutchinson Metropolitan Area. The O-D survey was conducted in accordance with standard procedures pre- 
TABLE 1

CITIES OF KANSAS HAVING POPULATION OVER 10,000*

City

Wichita

* Kansas City

Topeka

Salina

* Overland Park

Hutchinson

* Preirie Village

Lawrence

Leavenworth

Manhattan

Junction City

Pittsburg

Great Bend

Coffeyville

Emporia

Libera1

Newton

Arkansas City

Dodge City

Parsons

E1 Dorado

Garden City

Hays

Atchison

Independence

* "Shawnee

Ottawa

Olathe

Chanute

Winfield
Population

247,557

126,236

120,799

43,090

40,796

37,873

26,873

26,132

23,707

21,410

20,944

18,737

17,885

17,030

16,763

14,806

14,704

14,696

13,303

13,014

12,614

12,575

12,301

12,126

11,387

11,387

11,237

10,776

10,666

10,522

* Populations as of January 1, 1962 as reported by county assessors and compiled by the Kansas State Board of Agriculture.

* Included within Kansas City, Kansas Metropolitan Area. 
scribed by the Bureau of Public Roads. The internal survey was made by the home-interview method in which a 1 in 5 (20 per cent) dwelling unit sample was taken. The data gathered in the internal O-D survey and the land use study were used in this research.

Among the data collected for each surveyed dwelling unit in the internal O-D survey were the following:

Number of persons

Number of employed persons

Number of cars owned

Age groups

Number of vehicular trips

Trip purposes at origins and destinations

Mode of travel for each trip

The land use study recorded the following major groupings of

land use by zone in 1000's of square feet:

Residential
Manufacturing
Retail trade
Wholesale and warehouse
Transportation
Construction
Personal, business, repair services and office

Government and utility

Other open space - - streets, alleys, rivers, lakes, etc.

Recreation and institution

Appendix A shows the land use categories recorded within each major grouping.

The research was carried out in the following steps:

1. The preparation of O-D survey data for use in the research.

2. The selection of zones for use in the sample study.

3. The development of equations for estimating zonal productions.

4. The selection of samples in the 14 zones.

5. The development of equations for estimating zonal attractions.

6. The development of travel time factors.

7. The analysis of the study results. 


\section{Preparation of O-D Survey Data for Use in the Research}

The information obtained from the internal O-D survey (here-' after referred to as the O-D data or O-D survey data) was, for the most part transferred to tabulating machine punch cards and was available to the researcher from the beginning of the research project. The cards were of two general types: Card 1, referred to as the dwelling unit card (only one Card 1 existed per sampled dwelling), contained information on the zone in which the dwelling unit was located, the number of cars owned by persons living in the dwelling unit, the number of persons living in the dwelling unit and information on the number of trips made on the day (the trip day) prior to the interview. Card 2, referred to as the trip card, contained information on the location zone of the home (or dwelling unit), the zone of origin of the trip, the zone of destination of the trip, the land use category at both destination and origin of the trip, mode of travel, the number of persons in the car and the purpose of travel of each end of the trip. There was a Card 2 for each trip recorded at a sampled dwelling unit.

\section{Classification of Trips by Purpose}

In most model studies the trips have been studied by grouping them into a number of trip purposes. After studying the O-D survey data, initially it was decided that the five trip-purpose groupings; home-miscellaneous and non-home, would be studied instead of the following O-D survey trip-purpose categories: 


$\begin{array}{ll}\text { Work } & \text { Change travel mode } \\ \text { Business } & \text { Eat meal } \\ \text { Medical-dental } & \text { Shopping } \\ \text { School } & \text { Home } \\ \text { Social-recreation } & \text { Serve passenger }\end{array}$

In an origin-destination survey, one trip ends and another begins every time a person changes his mode of travel, an auto-driver stops to serve a passenger, or when the trip-maker reaches a destination. In the first two cases, if each of these trips were analyzed separately, the relationships among the actual starting point, the destination and the purpose of trip would be lost. It would also be difficult to relate the type and intensity of trip making to the type and intensity of land use. Consequently, it is desirable to combine or link those trips which have a "change travel mode" or "serve passenger" purpose so that the relationship between the purpose of the trip and the destination of the trip is preserved. Suppose, for example, that an autodriver drives his car from his home to the home of a co-worker where he picks up his co-worker and they both proceed to work. In this case, the auto driver's travel would be recorded as two separate auto-driver trips, the first one from "home" to "serve passenger" and the second one from "serve passenger" to "work". Since the auto-driver.'s purpose was to get to work, it is desirable for analysis purposes to "link" the two trip records into one which covers the entire journey. In this case, the auto-driver's "linked" trip would become a "home to work" trip by automobile. Similar reasoning could be used on travel involving change of travel mode. 
Trip linking may not be necessary in all cases. In many small cities where "change travel mode" trips may be small in number because of lack of transit facilities and where "serve passenger" trips may also be small in number because of the absence of car poolings, trip linking may be unnecessary (12). However, in studying the Hutchinson data it was found that although "change travel mode" trips were negligible, the "serve passenger" trips made up approximately 23 per cent of all auto driver trips. It was, then, considered necessary to link these trips. The linking was accomplished by hand rather than with an electronic computer. In this case, it was judged to be more expedient to "hand" link than to prepare a computer program for the process. Trip linking in a large metropolitan survey area would, no doubt, be most efficiently carried out by the use of a high speed computer. The Bureau of Public Roads, in fact, has such a "trip linking" program for use on the IBM 1401 (12).

In the linking process for Hutchinson about 2, 400 "trips" were lost. That is, there were 2,400 trips that made up a part of a journey with such trips not being meaningful to the major trip purpose. With the "serve passenger" trips linked or converted into meaningful purposes, the original ten trip purposes were combined into five trip purpose categóries. Eventually it was found, because of the small numbers involved, to be more satisfactory to use only three trip purpose categories.

Two general classifications of trips are usually made because of differences in treatment of trip productions and attractions, and 
Two general classifications of trips are usually made because of differences in treatment of trip productions and attractions, and because of the numbers of trips involved. They are, first, the trips in which one end of the trip is the home (home-based trips) and, second, the remaining trips in which neither end is the home (the non-home-based trips). Table 2 and Table 3 indicate that the major purposes of home-based trips were:

Work

Shopping

Social-recreation

Using these three categories for home-based trips and combining all other home-based trips into one category, and all non-home-based trips into another category resulted in five trip purpose groups with percentages of trips in each group as shown in Table 4. During the process of developing estimating equations for trip productions and attractions, as well as in the calibration of the model by purpose, the relatively small numbers of trips in the home-based social-recreation, shopping and miscellaneous trips appeared to be responsible for much of the variability of results being obtained. In view of this, the trip purpose groups were further combined as shown in Table 5 . The discussions throughout the remainder of this report relate to the three trip-purpose groups, home-work, home-other, and non-home trips as shown in Table 5 . 


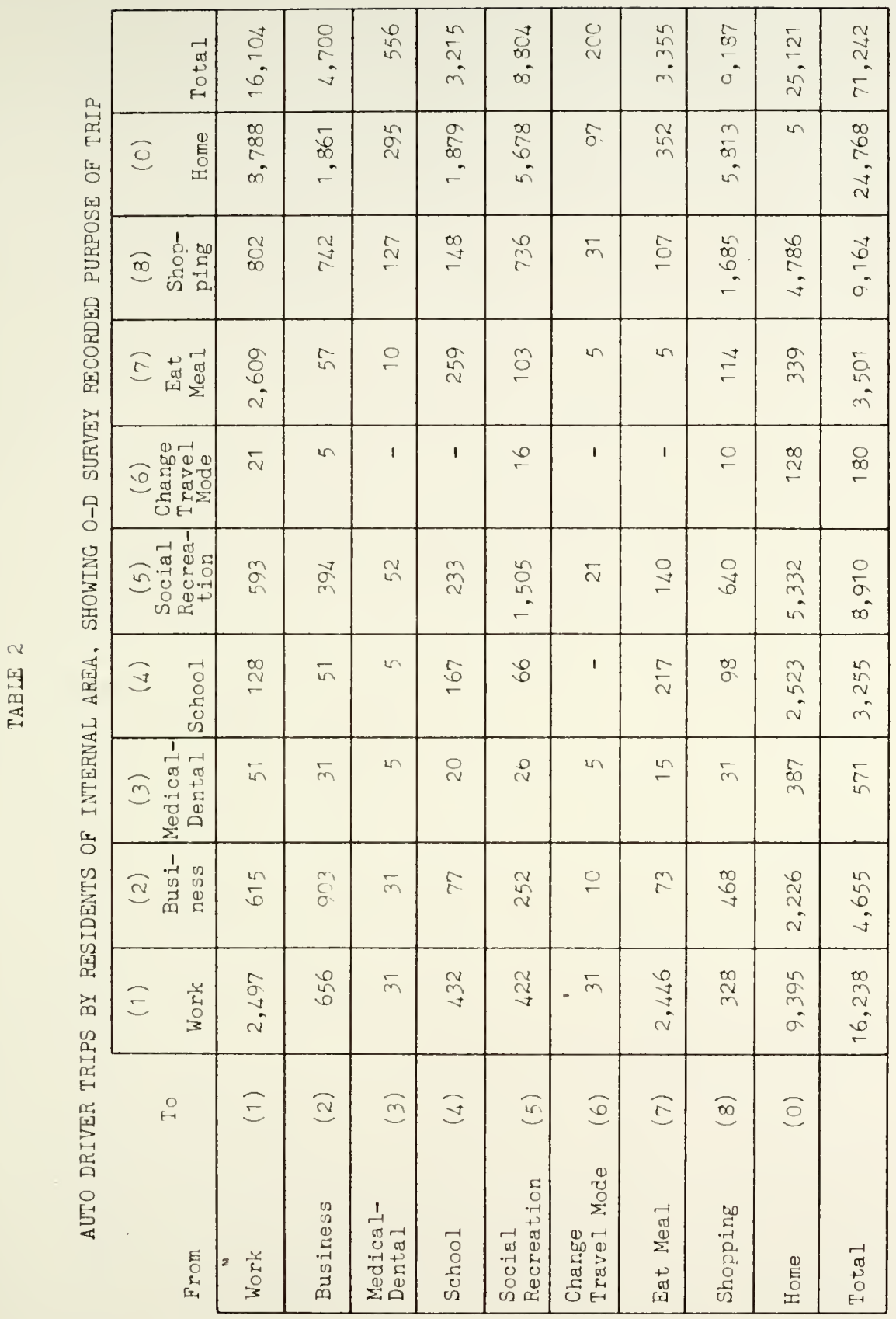




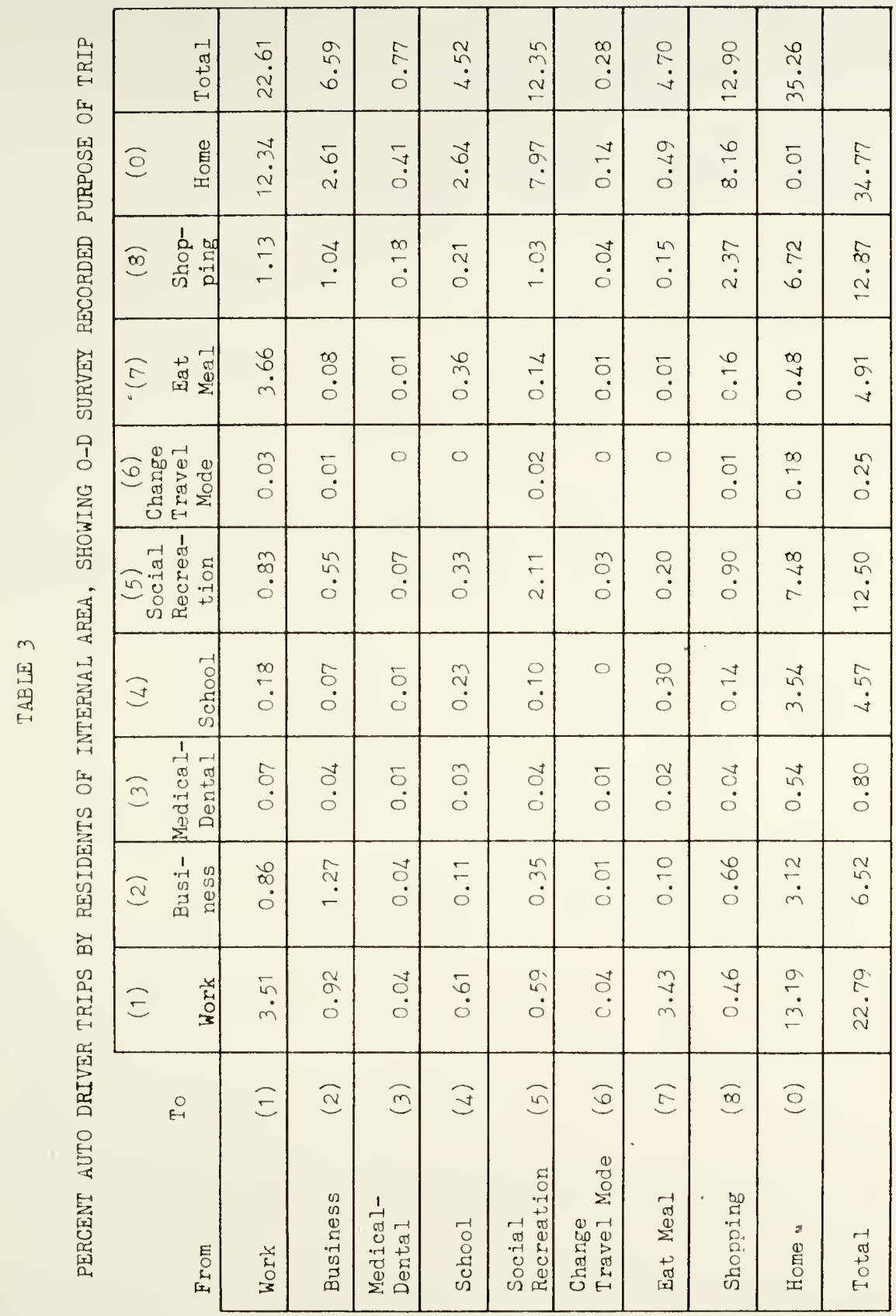




\section{TABLE 4}

AUTO DRIVER TRIPS - BY PURPOSE OF TRIP* (INITIAL)

\begin{tabular}{|c|c|c|c|}
\hline & $\begin{array}{c}\text { Number } \\
\text { of Trips } \\
\end{array}$ & $\begin{array}{l}\text { Percent } \\
\text { of Trips }\end{array}$ & $\begin{array}{l}\text { Trip Purpose Code } \\
\text { for the Study }\end{array}$ \\
\hline Home - Work & 18,183 & 25.53 & 0 \\
\hline Home - Social-Recreation & 11,010 & 15.45 & 1 \\
\hline Home - Shopping & 10,599 & 14.88 & 2 \\
\hline Home - Miscellaneous ${ }^{*}$ & 10,092 & 14.16 & 3 \\
\hline Non - Home & 21,358 & 29.98 & 4 \\
\hline TOTAL & 71,242 & 100 & \\
\hline
\end{tabular}

* Initial trip-purpose categories for the study.

* Includes home - business, medical-dental, school, change travel mode and eat meal.

TABLE 5

AUTO DRIVER TRIPS - BY PURPOSE OF TRIP*

\begin{tabular}{cll}
$\begin{array}{c}\text { Number } \\
\text { of Trips }\end{array}$ & $\begin{array}{l}\text { Percent } \\
\text { of Trips }\end{array}$ & $\begin{array}{l}\text { Trip Purpose Code } \\
\text { for the Study }\end{array}$ \\
\hline
\end{tabular}

Home - Work

Home - Other**

Non - Home
18,183

31,701

$\underline{21,358}$

71,242
25.53

44.49

29.98

100

TOTAL

* Final trip-purpose categories for the study.

* Includes home - social-recreation, shopping and miscellaneous. 


\section{Additional Data Obtained}

The number of employed persons per dwelling unit was determined from the home interview sheets and was placed in each dwelling unit card. Persons classified as non-gainfully employed workers, which included housewives and other unpaid home workers, retired workers, persons permanently incapacitated for any gainful employment and students were not included in the employed persons totals.

The net area of residential land use per dwelling unit was obtained and was placed in each dwelling unit card. This was determined in the following manner: The area of residential land in a given zone less the vacant land zoned residential was divided by the number of dwelling units in the zone. The area was recorded in 1000 's of square feet per dwelling unit.

The driving time from the centroid of each zone to the Central Business District (CBD) was determined to the nearest 0.1 minute from the time-trees developed from a travel-time study in Hutchinson.

Prior to the development of estimating equations for work trip attractions, it was decided, as was found in an lowa study (9), that the number of jobs in a zone would be expected to be a potent indicator of home-work trip attractions. Information on various categories of employment in each zone was therefore collected. An attempt was made to determine the employmend in the various zones as it existed at the time the O-D survey was made, but it was possible to determine only major changes in employment. A very good correlation, however, of total number of jobs in the survey area with 
the 1960 Census data was obtained.

The employment study was made in the Hutchinson Office of the Kansas State Employment Service. Due to the excellent cooperation of the employment service personnel, the survey was completed within three days with two persons collecting most of the data. The number of employees in each of the ten types of business and industry listed below, and the number of self-employed persons were tabulated by zone.

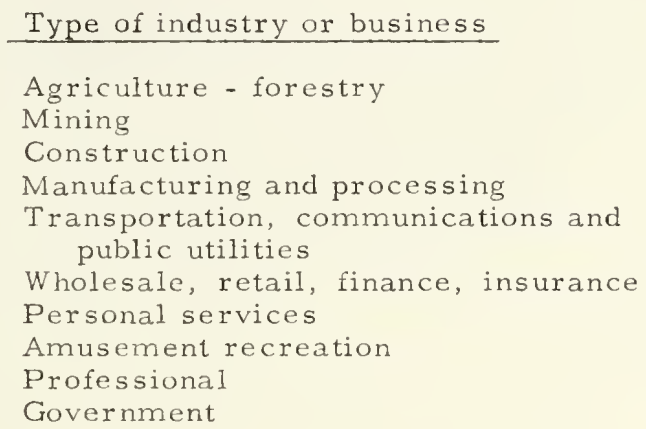

Selection of Zones for use in the Reduced Sample Study

Zones were selected for the reduced sample survey so that they would reflect a range in such zonal characteristics as residential density, car ownership rate, population density, distance from the central business district and distance to the nearest large employment center. An investigation of the Hutchinson data showed that the principal $\mathrm{CBD}$ zone, 12, was, in fact, the large employment center in the city. A zonal map (Figure 1) was used in selecting the zones. For each zone having any significant number of dwelling units, the number of dwelling units, cars owned by residents of the zone, total number 
of persons residing in the zone, cars per dwelling unit, and persons per dwelling unit were noted on a zone map.

The selection of zones was further based upon opinions of those familiar with the nature of residential areas in Hutchinson such that zones of varying economic status or value of residence would be chosen.

Zones 12, 16, 33, 51, 64, 75, and 77 were chosen for initial study; however, in the analysis concerning the estimation of trip productions and attractions, it was found that seven zones were inadequate for the intended use. Additional zones 14, 24, 53, 57 , 59,61 , and 62 were chosen for the remaining analysis.

Pertinent data on all zones, as well as the fourteen selected zones, are shown in Table 6. In Table 6, the numbers in the column titled "Total Dwelling Units" were obtained by multiplying the number of sample dwelling units within a zone by the dwelling unit factor (D. U.F.) for that zone. A sample dwelling unit was taken as any dwelling unit in which an interview was intended to be made. Thus, vacant dwelling units, dwelling units in which residents refused to answer questions, dwelling units in which no one was found at home or in which contagious sickness was found, and dwelling units in which survey questions were answered comprised the total of sample dwelling units in a given zone.

The dwelling unit factor for each zone was calculated as follows:

$$
\text { D. U.F. }=\frac{A-\left(\frac{C A}{B}\right)}{B-(C+D)}
$$


where
$A=$ Total number of addresses in the zone
$\mathrm{B}=$ Total number of addresses, in the zone, initially selected as sample dwelling units found to be vacant, demolished or used for commercial purposes only
$C=$ The sum of sample dwellings within the zone
- $\mathrm{D}=$ The sum of interviews within the zone "missed"
because of contagious sickness in the household, no one found at home or residents refused to answer questions.

Note: When "D"' is zero, D. U.F. $=\frac{A}{B}$.

The numbers in the column, in Table 6, titled "Dwelling Units"* were obtained by multiplying, for each zone, the dwelling unit factor by the number of sample dwellings in which answers to the survey questions were obtained.

\section{$\frac{\text { The Development of Equations for }}{\text { Estinating Zonal Productions }}$}

Early attempts were made to develop estimating equations based upon groups of samples within each of the seven initially selected zones. It was hoped that interviews obtained in a single zone could be grouped into small subsamples that would give good estimates of the productions and attractions of that particular zone.

Information concerning the assessed evaluation per dwelling unit in Zone 75 (see Figure 1) was obtained in a two-day study of the city records in Hutchinson. The "evaluation" data were tęsted for value as an "economic" indicator in the production of trips. The results were inconclusive since the trip production based upon the sub- 
TABLE 6

ZONAL CHARACTERISTICS

\begin{tabular}{|c|c|c|c|c|c|c|c|}
\hline & & & xpanded & Sample Da & & & \\
\hline Zone & $\begin{array}{c}\text { Total } \\
\text { Dwelling } \\
\text { Units }\end{array}$ & $\begin{array}{c}\text { Dwe1ling } \\
\text { Units* }\end{array}$ & $\begin{array}{l}\text { Total } \\
\text { Cars } \\
\text { Owned }\end{array}$ & $\begin{array}{c}\text { Total } \\
\text { Persons }\end{array}$ & $\begin{array}{c}\text { CBD } \\
\text { Distance } \\
\text { (Min.) }\end{array}$ & $\begin{array}{c}\text { Area/DU } \\
(\mathrm{Sq} \cdot \mathrm{Ft} .)\end{array}$ & $\begin{array}{l}\text { Total } \\
\text { Jobs }\end{array}$ \\
\hline $12 \times 2 x$ & 293 & 245 & 156 & 341 & 0.5 & 2300 & 5000 \\
\hline 13 & 66 & 51 & 36 & 143 & 2.0 & 6110 & 614 \\
\hline $14 * x$ & 754 & 656 & 588 & 1695 & 1.4 & .5402 & 361 \\
\hline 15 & 337 & 271 & 224 & 975 & 2.9 & 8601 & 32 \\
\hline $16 * *$ & 434 & 393 & 374 & 1343 & 4.3 & 8602 & 197 \\
\hline 17 & 164 & 118 & 72 & 398 & 2.7 & 8710 & 169 \\
\hline 18 & 541 & 453 & 325 & 1410 & 1.7 & 6403 & 615 \\
\hline 19 & 464 & 422 & 457 & 1398 & 2.9 & 7797 & 175 \\
\hline 20 & - & - & - & - & 4.1 & - & 72 \\
\hline 21 & - & - & - & - & 5.6 & - & 9 \\
\hline 22 & - & - & - & - & 6.2 & - & 3 \\
\hline 23 & 15 & 15 & 15 & 26 & 5.5 & 6140 & 226 \\
\hline $24 * *$ & 270 & 250 & 347 & 864 & 5.7 & 11301 & 21 \\
\hline 25 & - & - & - & - & 10.1 & 12500 & 171 \\
\hline 26 & - & - & - & - & 5.5 & 12500 & - \\
\hline 27 & 40 & 40 & 60 & 134 & 7.7 & 16380 & 19 \\
\hline 28 & 25 & 25 & 35 & 114 & 8.3 & 15450 & 4 \\
\hline 29 & 5 & 5 & 5 & 10 & 10.6 & 12500 & 4 \\
\hline 30 & - & - & - & - & 3.0 & - & 45 \\
\hline 31 & - & - & - & - & 4.2 & - & 90 \\
\hline 32 & 55 & 55 & 70 & 174 & 3.9 & 11150 & 73 \\
\hline $33 * *$ & . 298 & 284 & 358 & 1080 & 5.7 & 13799 & 56 \\
\hline 34 & 5 & 5 & 5 & 15 & 3.9 & 12500 & 127 \\
\hline 35 & 35 & 20 & 15 & 61 & 4.6 & 23350 & 130 \\
\hline 36 & 41 & 31 & 41 & 81 & 4.3 & 2610 & $15^{\circ}$ \\
\hline 37 & 5 & - & - & - & 4.6 & - & - \\
\hline 38 & - & - & - & - & 5.3 & - & 5 \\
\hline 39 & 41 & 41 & 56 & 132 & 6.4 & 22280 & 12 \\
\hline 40 & 10 & 10 & 10 & 36 & 6.0 & 12500 & 184 \\
\hline 41 & - & - & - & - & 12.0 & - & 3 \\
\hline 42 & 81 & 81 & 132 & 234 & 7.7 & 34560 & 11 \\
\hline 43 & 15 & 15 & 10 & 36 & 9.4 & 12500 & 4 \\
\hline 44 & 10 & 10 & 15 & 41 & 7.8 & 12500 & 4 \\
\hline, 45 & 46 & 46 & 66 & 178 & 7.4 & 14950 & 6 \\
\hline 46 & 5 & 5 & 15 & 20 & 8.6 & 12500 & - \\
\hline 47 & - & - & - & - & 10.7 & - & - \\
\hline 48 & 5 & 5 & 5 & 30 & 12.6 & 12500 & - \\
\hline 49 & - & - & - & - & 14.0 & - & - \\
\hline 50 & 117 & 100 & 58 & 144 & 1.6 & 1630 & 1150 \\
\hline $51+x$ & 1472 & 1244 & 1236 & 3573 & 2.9 & 1126 & 766 \\
\hline 52 & 32 & 27 & 21 & 112 & 3.3 & 7850 & 100 \\
\hline 53 첫 & 966 & 850 & 778 & 2319 & 3.3 & 5799 & 437 \\
\hline
\end{tabular}


TABLE 6 (Cont.)

\begin{tabular}{|c|c|c|c|c|c|c|c|}
\hline \multicolumn{8}{|c|}{ Expanded Sample Data } \\
\hline Zone & $\begin{array}{c}\text { Total } \\
\text { Dwelling } \\
\text { Units }\end{array}$ & $\begin{array}{c}\text { Dwelling } \\
\text { Units* }\end{array}$ & $\begin{array}{l}\text { Total } \\
\text { Cars } \\
\text { Owned }\end{array}$ & $\begin{array}{c}\text { Total } \\
\text { Persons }\end{array}$ & $\begin{array}{c}\text { CBD } \\
\text { Distance } \\
\text { (Min.) }\end{array}$ & $\begin{array}{c}\text { Area/DU } \\
(\mathrm{Sq} \cdot \mathrm{Ft} .)\end{array}$ & $\begin{array}{r}\text { Total } \\
\text { Jobs }\end{array}$ \\
\hline 54 & 133 & 112 & 138 & 401 & 3.9 & 12460 & - \\
\hline 55 & 32 & 32 & 48 & 70 & 3.9 & 17410 & 146 \\
\hline 56 & 94 & 94 & 125 & 324 & 6.1 & 16460 & 153 \\
\hline $57 * x$ & 313 & 275 & 349 & 840 & 5.9 & 13601 & 99 \\
\hline 58 & 534 & 493 & 567 & 1414 & 5.2 & 10002 & 65 \\
\hline $59 x x$ & 603 & 540 & 551 & 1576 & 4.3 & 5701 & 166 \\
\hline 60 & 861 & 824 & 1021 & 2387 & 5.0 & 1311 & 190 \\
\hline $61^{* *}$ & 357 & 292 & 402 & 986 & 6.3 & 7799 & 251 \\
\hline $62^{* *}$ & 413 & 384 & 454 & 1524 & 7.4 & 10302 & 61 \\
\hline 63 & 1163 & 1074 & 1151 & 3470 & 4.5 & 2969 & 513 \\
\hline $64^{x+x}$ & 574 & 539 & 575 & 1781 & 5.8 & 1775 & 155 \\
\hline 65 & 90. & 74 & 96 & 265 & 7.7 & 7500 & 604 \\
\hline 66 & - & - & - & - & 8.8 & - & 809 \\
\hline 67 & 64 & 60 & 79 & 243 & 9.7 & 29130 & 50 \\
\hline 68 & - & - & - & - & 11.1 & - & 85 \\
\hline 69 & - & - & - & - & 9.2 & - & 62 \\
\hline 70 & - & - & - & - & 6.8 & - & - \\
\hline 71 & 171 & 144 & 203 & 621 & 11.2 & 37620 & 17 \\
\hline 72 & 91 & 81 & 111 & 258 & 8.7 & 13500 & 69 \\
\hline 73 & - & - & - & - & 6.4 & - & 234 \\
\hline 74 & 655 & 620 & 855 & 1890 & 6.2 & 1835 & 123 \\
\hline $75^{* x+}$ & 698 & 641 & 854 & 2157 & 6.7 & 1153 & 163 \\
\hline 76 & 258 & 243 & 400 & 869 & 7.3 & 15298 & 78 \\
\hline $77 * x$ & 495 & 464 & 676 & 1471 & 7.3 & 5188 & 76 \\
\hline 78 & 31 & 31 & 87 & 102 & 6.8 & 36970 & 13 \\
\hline 79 & 31 & 31 & 61 & 92 & 3.7 & 26670 & 18 \\
\hline 80 & 5 & 5 & 5 & 19 & 12.1 & 12500 & 3 \\
\hline 81 & 14 & 14 & 19 & 38 & 10.8 & 12500 & .11 \\
\hline 32 & - & - & - & - & 11.6 & - & 1 \\
\hline 83 & 10 & 10 & 10 & 46 & 11.7 & 12500 & 7 \\
\hline 84 & 67 & 67 & 87 & 256 & 12.8 & 18880 & 7 \\
\hline 85 & 46 & 46 & 82 & 200 & 12.6 & 32790 & 84 \\
\hline 86 & - & - & - & - & 11.5 & - & 19 \\
\hline 87 & 55 & 55 & 89 & 188 & 10.7 & 20710 & 59 \\
\hline 88 & 5 & 5 & 10 & 31 & 14.9 & 12500 & - \\
\hline 89 & 10 & 10 & 15 & 30 & 14.9 & 12500 & 1 \\
\hline 90 & - & - & - & - & 16.9 & - & - \\
\hline 91 & - & - & - & - & 16.2 & - & 2 \\
\hline 92 & 25 & 25 & $30^{\circ}$ & 94 & 13.6 & 12500 & 9 \\
\hline 93 & 5 & 5 & 10 & 35 & 12.0 & 12500 & 6 \\
\hline 94 & 15 & 15 & 15 & 69 & 13.6 & 12500 & 15 \\
\hline
\end{tabular}

* No. Dwelling Units Answering Survey Questions x Dwelling Unit Factor ** Indicates 14 selected zones 
samples showed such a great amount of variability. Examination of the evaluation study indicated that such a study for each zone in the area would probably not produce data that would be of significant aid in the estimation of zonal trip productions and attractions. It was also believed that the number of "employed persons per dwelling unit" might be a better indicator of work trip production than "persons per dwelling unit." In order to test this hypothesis, four sets of regression equations were developed using, among the variables, either "persons per dwelling unit" or "employed persons per dwelling unit". The data used were from the comprehensive survey for the 22 zones which contained more than 125 dwelling units. There was less than one per cent difference between the value of $R^{2}$, the coefficient of determination, for each pair of equations. It was concluded, therefore, that "employed persons per dwelling unit" was no better indicator of work trip production than was "persons per dwelling unit"'.

Due to the great variability among subsamples as well as the problems anticipated in gathering data on zonal characteristics in such small areas. the estimation of productions was carried out using zonal averages of such information as cars and persons per dwelling unit, area of residential land per dwelling unit and distance to the CBD in minutes. The development of the estimating equations was carried out using the multiple regression technique in which the form of an equation is estiniated and the coefficient of each term is obtained from the "least squares" best fitting curve. The measure of fit was obtained as an output of the computer program used (13). 
The SCRAP "Sixteen-twenty Card Regression Analysis Program," used in this research, is one of a number of such programs available in most computing centers. It became apparent early in the investigation that, for productions, as many as seven terms would probably be required in the estimating equation. Seven zones would give only seven pieces of data and the computer program, in essence, was able to pass a curve through each point represented by the data. This situation does not allow one to predict, statistically, the goodness of fit of the estimating equation to other zones one might consider. After consultation with statisticians, it was decided that a minimum of 14 zones ( 7 additional zones) would be required if a 7 -term estimating equation were to be used. Data from 14 zones, giving 14 pieces of information, were judged to give a satisfactory statistical estimate of the "predictive" power of the estimating equation. A minimum of seven degrees of freedom was judged to be required.

Two sets of estimating equations of trip production were developed. One was based upon zonal characteristics obtained from each of 22 zones as a result of sampling 20 per cent of the dwelling unites in each zone. The 22 zones were those zones in which over 25 dwelling units vere sampled. In essence, the 22 zones represented the universe of zones which were of substantial size.

The second set of equations was based upon zonal characteristics obtained from each of the previously mentioned 14 selected zones. However, in this case, a sampling rate was established for each zone. 
In order that the total number of non-home-based trip productions could be estimated, non-home-based trips were treated precisely as home-based trips. These "productions" represented only the number of non-home trips made by the residents of each zone and did not distribute the trips according to location of trip end. A regression analysis, similar to the analysis used for home-based productions, was made on these trips with the resulting equation, as expanded to the entire area, giving the total number of non-home trip productions or attractions. This number was later used in expanding the non-homebased productions to this estimated total (see the discussion concerning estimation of non-home productions and attractions).

Selection of Reduced Samples

The selection of the reduced sample size in the 14 selected zones was made in accordance with research conducted by Sosslau and Brokke for the Bureau of Public Roads (14).

In order to use Figure 4, it is necessary to estimate the number of trips per zone and to select a root-mean-square (RMS) error that is acceptable. One can then enter Figure 4 and select the appropriate rate of sampling.

A level of accuracy yielding an expected RMS error of zonal trip production of fifteen per cent or less was agreed as acceptable." The estimation of trips produced per zone was made and, in this

" case, the city wide average was about five auto-driver trips per dwelling unit. Where an estimate of this average is not available for a city, studies of trip making characteristics of similar cities should 


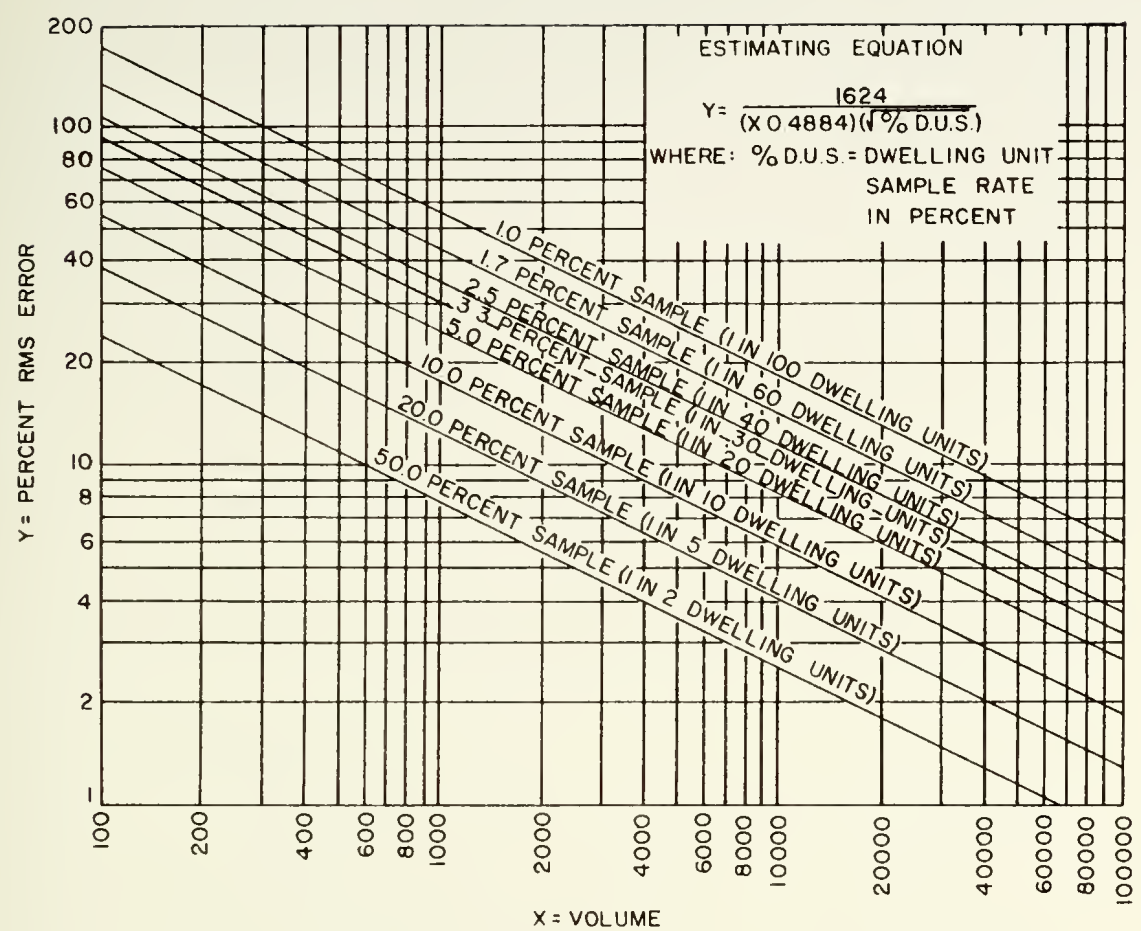

For rates not plotted, the following equation can be used:

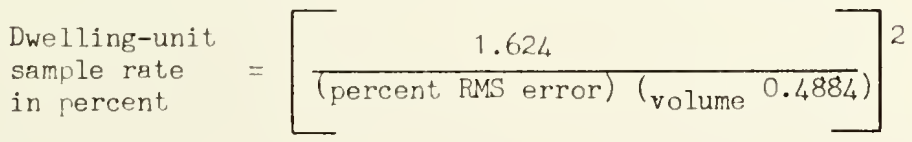

FIGURE 4 *

RELATION OF PERCENT ROOT-MEAN-SQUARE ERROR AND VOLUME FOR VARIOUS DWELEING UNIT SAMPLE RATES

* Source: Reference (14) 
suffice for this estimate.

Figure 4 was entered with $\mathrm{X}$, the estimated volume of trips in a given zone, and the 15 per cent RMS error line indicated the minimum percentage of dwelling units to be sampled in that zone. The subsample was drawn from the O-D sample and was selected by a computer program.

The subsample in Zone 12 was selected as follows:

1. Estimated Trips $=5 \times 270$ dwelling units $=1,350$.

2. Enter Figure 4 with 1, 350 and intersect the horizontal 15 per cent RMS error line.

3. Read $15 \pm$ per cent sample.

4. A I5 per cent sample is equivalent to $3 / 4$ of a 20 per cent sample (the existing sample size).

5. The computer program was devised to select the dwelling unit and trip cards for every $n^{\text {th }}$ sampled dwelling unit and in this case a random selection of a number from 1 to 4 was made to indicate the starting sample and thereafter every fourth "dwelling unit" sample was selected. This group was discarded and the remaining $3 / 4$ of the original 20 per cent sample was taken. The original expansion factors were multiplied by the ratio of the original number of sampled dwelling units to the reduced number of sampled dwelling units and this new expansion factor was placed in the dwelling unit and trip cards for the "reduced samples".

Table 7 shows the sample size selected in each of the 14 zones.

Tables 8 and 9 show zonal characteristics for the 14 zones for the full as well as the reduced sample, respectively.

Tables 10 and 11 show the trip attractions and non-home productions per trip produced for the 14 zones for the full as well as the reduced sample, respectively. 
* $4 \frac{0}{0}$

की

त 40

की

fic

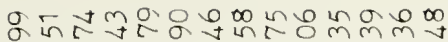

ம0்

\&े

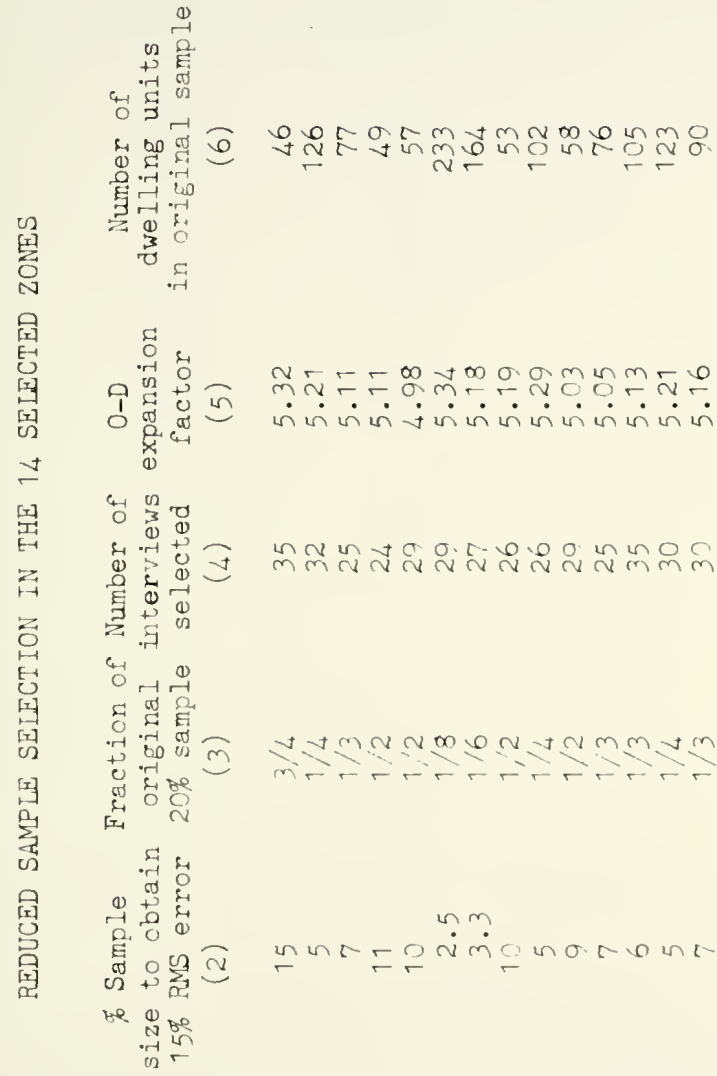

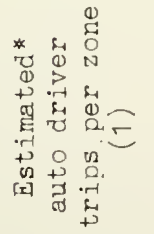

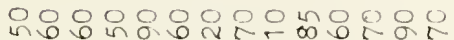

m

On

I

c.

ज 弯 至

豆

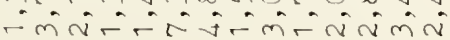

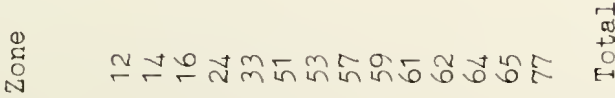


TABLE 8

ZONAL CHARACTERIS'TICS USED FOR TRIP PRODUCTION ESTIMATEO DATA FROM O-D FULL SAMPLE IN TIEE 14 SELECTEI) LONL;

\section{Cars Per Persons Per}

Trips Per Dwelling Unit

Zone Dwelling Unit Dwelling Unit Home-Work Home-Other Non-Home*

12

.630

$1: 391$

2.660

3.741

2.844

2. 685

3.000

2.932

3.379

3.974

3.256

3.337

3.166
]. 322

1.455

(2)

.283

1. 342

1.351

1.735

1.655

1.130

2.025

2.182

3. 204

3.414

1.965

1. 473

2.171

2.049

3.103

2.750

2.114

2.555

4.211

1.314

1. 435

4. 21
.609

1.048

1. 325

2. 000

1.948

1.003

.673

1.566

.981

2.741

2. 698

1.095

2.813

3.155

* Used only for eștimation of total non-home trips produced in the mecropolitan study area. 
TABLE 9

ZONAL CHARACTERISTICS USED FOR TRIP PRODUCTION ESTIMATES

DATA FROM O-D REDUCED SAMPLE IN THE 14 SELECTED ZONES

\section{Cars Per Persons Per}

Trips Per Dwelling Unit

Zone Dwelling Unit Dwelling Unit Home-Work Home-Other Non-Home*

$\begin{array}{rrrrrr}12 & .629 & 1.371 & .229 & 1.057 & .486 \\ 14 & .781 & 2.406 & 1.063 & 1.188 & .438 \\ 16 & .960 & 2.920 & 1.480 & 1.600 & 1.440 \\ 24 & 1.500 & 3.542 & 1.583 & 3.708 & 2.047 \\ 33 & 1.207 & 3.965 & 2.103 & 3.000 & 1.758 \\ 51 & 1.172 & 2.758 & 1.138 & 1.966 & .828 \\ 53 & .963 & 2.630 & 1.259 & 1.816 & .741 \\ 57 & 1.038 & 2.923 & 1.115 & 2.462 & 1.846 \\ 59 & 1.000 & 2.885 & 1.385 & 2.930 & 1.115 \\ 61 & 1.276 & 3.207 & 1.827 & 2.551 & 3.600 \\ 62 & 1.160 & 4.200 & 1.920 & 2.560 & 2.342 \\ 64 & .943 & 3.000 & 1.371 & 1.571 & 1.029 \\ 75 & 1.300 & 2.933 & 1.433 & 2.833 & 3.066 \\ 77 & 1.567 & 3.366 & 1.800 & 5.200 & 4.566\end{array}$

* Used only for estimation of total non-home trips produced in the metropolitan study area. 
TABLE 10

TRIP ATTRACTIONS AND NON - HOME PRODUCTIONS FROM

O-D FULL SAMPLE DATA FROM THE 14 SELECTED ZONES

$\underline{\text { Zone }}$

Trip Attractions per Trip Produced

Trip Production per Trip Produced Home - Work Home - Other Non - Home

Non - Home

12

.319

.037

.028

.010

.008

.050

.016

.009

.001

$---$

.003

.010

.001

.001

.001

28

30

31

32

33

34

35

36

37

38

39

40

41

42

43

44

45

46

47

48

49

50

$---$

.004

.004

.005

.009

.006

---

.001

---

.013

$--$

$--$

$--$

.001

---

$---$

51

.074

.196

.014

.029

.009

.015

---

.015

.018

.001

.009

.002

.002

.006

-.-
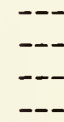

.001

.004

.003

.020

.024

.007

$---$

.004

.001

---
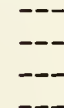

.001

---

$---$

.092

.083

.003

.006

.063

.252

.024

.038

.005

.011

.001

.040

.015

.001

.002

.001

.002

.011

.002

$--$

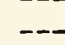

---

.002

.005

.011

.013

.006

.273

.027

.037

.003

.013

.002

.041

.014

.003

.001

.004

.008

.004

52

53

.028
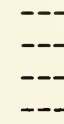

.001
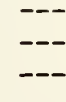

.002

$--$
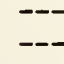

.077

.078

.004

.062

.002

.003

.004

.014

.014

.006

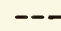

$-$

$--$

$-$

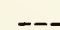

.001

---

.001

---

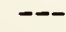

$--$

.087

.072

.004

.052 
TABLE 10 (Cont1nued)

Zone

Trip Attractions per Trip Produced

Home - Work Home - Other Non - Home

Trip Production per Trip Produced

$54 \quad .001$

$55 \quad .012$

$56 \quad .010$

$57 \quad .004$

$58 \quad .004$

$59 \quad .013$

$60 \quad .014$

$61 \quad .025$

$62 \quad .004$

$63 \quad .027$

$64 \quad .010$

$65 \quad .036$

$\begin{array}{ll}66 & .043\end{array}$

$67 \quad .004$

$68 \quad .003$

69

70

71

72

73

74

75

76

77

78

79

80

81

82

83

84

85

86

87

88

89

90

91

92

93

94

.001

---

.001

---

.004

.002

.004

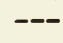

---

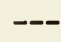

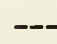

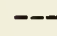

.003

.002

.003

.008

.010

.036

.052

.044

.010

.060

.023

.006

.001

---

.003

---

.003

.005

.023

.019

.016

.016

.023

.003

---

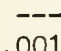

$--$

.002

.003

.001

.001

.001

---

---

$-$
.002

.005

.003

.013

.009

.027

.028

.027

.021

.046

.019

.013

.005

.002

.004

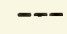

$---$

.002

.005

.011

.014

.028

.005

.032

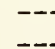

---

.001

$--$

$--$

.001

.002

---

.001

.001

$--$

$--$

$--$
Non - Home

.001

.005

.003

.012

.007

.025

.025

.031

.020

.034

.019

.015

.008

.003

.005

---

.001

.004

.014

.013

.023

.007

.027

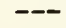

--

.001

$--$ 
TABLE 11

TRIP ATTRACTIONS AND NON - HOME PRODUCTIONS FROM O-D REDUCED SAMPLE DATA FROM THE 14 SELECTED ZONES

\begin{tabular}{|c|c|c|c|c|}
\hline \multirow[t]{2}{*}{ Zone } & \multicolumn{3}{|c|}{ Trip Attractions per Trip Produced } & \multirow{2}{*}{$\begin{array}{c}\begin{array}{c}\text { Trip Production } \\
\text { per Trip Produced }\end{array} \\
\underline{\text { Non - Home }}\end{array}$} \\
\hline & Home - Work & Home - Other & Non - Home & \\
\hline 12 & .368 & .215 & .282 & .313 \\
\hline 13 & .034 & .007 & .025 & .030 \\
\hline 14 & .030 & .024 & .025 & .028 \\
\hline 15 & -- & .006 & .005 & .002 \\
\hline 16 & .005 & .004 & .008 & .014 \\
\hline 17 & .006 & -- & .001 & .003 \\
\hline 18 & .051 & .008 & .034 & .034 \\
\hline 19 & .016 & .008 & .013 & .009 \\
\hline 20 & .015 & -- & .002 & -- \\
\hline 21 & 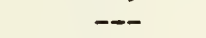 & .005 & --- & .001 \\
\hline 22 & -.- & -- & .002 & .002 \\
\hline 23 & .022 & .007 & .005 & .005 \\
\hline 24 & - & .004 & .008 & .007 \\
\hline 25 & .003 & --- & -- & .001 \\
\hline 26 & -- & --- & --- & -- \\
\hline 27 & --- & -- & --- & --- \\
\hline 28 & -- & --- & --- & -- \\
\hline 29 & -- & --- & -- & --- \\
\hline 30 & .002 & -- & .001 & .001 \\
\hline 31 & --- & .005 & .001 & -- \\
\hline 32 & .007 & .007 & .006 & .003 \\
\hline 33 & .007 & .021 & .009 & .010 \\
\hline 34 & .004 & .017 & .010 & .010 \\
\hline 35 & .002 & .004 & .002 & .003 \\
\hline 36 & -- & -- & --- & -. \\
\hline 37 & --- & --- & -- & --- \\
\hline 38 & .001 & .006 & --- & .001 \\
\hline 39 & --- & --- & --- & -- \\
\hline 40 & .025 & -- & .005 & .001 \\
\hline 41 & --- & .001 & -- & -- \\
\hline 42 & --- & --- & .002 & .004 \\
\hline 43 & --- & --- & -- & -- \\
\hline 44 & --- & --- & --- & --- \\
\hline 45 & --- & .001 & .004 & .003 \\
\hline 46 & --- & -- & $\ldots$ & -- \\
\hline 47 & .002 & :--- & $\cdots$ & --- \\
\hline 48 & --- & -- & --- & --- \\
\hline 49 & --- & -- & --- & -- \\
\hline 50 & .065 & .091 & .079 & .104 \\
\hline 51 & .046 & .093 & .081 & .062 \\
\hline 52 & .009 & .004 & .007 & .009 \\
\hline 53 & .029 & .089 & .074 & .057 \\
\hline 54 & -.- & .004 & .003 & .001 \\
\hline
\end{tabular}


TABLE 11 (Continued)

Zone

Home - Work Home - Other Non - Home

55

56

57

58

59

60

61

62

63

64

65

66

67

68

69

70

71

72

73

74

75

76

77

78

79

80

81

82

83

84

85

86

87

88

89

90

91

92

93

94

Trip Attractions per Trip Produced

.022

.012

.004

.005

.018

.048

.009

.018

.006

.024

.050

.006

.002

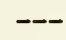

--.

$--$

.010

.008

.002

.009

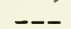

-..

$-$.

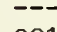

.001

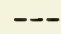

.002

$--$

$---$

.003

$--$

$--$

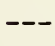

$--$

$--$

$--$

$--$
.004

.005

.015

.003

.038

.059

.038

.005

.055

.017

.004

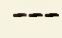

$-.-$

.005

$--$

$--$

.003

.023

.021

.022

.017

.020

.004

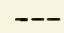

$--$

.002

$-\cdot-$

.010

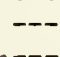

$\cdots$

.002

$---$

$--$

.001
.005

.003

.005

.005

.023

.027

.024

.020

.033

.017

.016

.011

.003

.003

$--$

-..

.011

.005

.014

.028

.007

.041

---
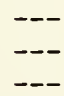

$---$

$--$

$--$

$--$

.001

.003

---

$--$

.001

$--$

.001
Trip Production per Tr1p Produced

Non - Home

.005

.001

.007

.005

.021

.018

.031

.016

.029

.019

.019

.010

.003

.004

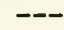

$---$

.006

.008

.015

.018

.008

.034

---

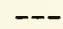

$--$

.001

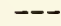

.002
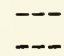

.001

.002
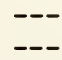
Figures 5, 6 and 7 show the trip length frequency distributions, by purpose, for the 14 zones for both the full and reduced samples. There were 402 dwelling units in the reduced samples in the 14 selected zones. The comprehensive O-D survey consisted of 1359 interviews obtained from a 20 per cent sample of dwelling units in the same 14 zones.

\section{The Development of Equations for

Estimating Zonal Attractions

The "SCRAP" regression analysis program (13) was used in developing the estimating equations for trip attractions by trip purpose.

There were two sets of equations developed for trip attractions: One set was obtained using the attractions as distributed according to the data from the reduced sample in the $1 t$ selected zones. The second set was obtained using data from the comprehensive O-D survey and utilized data from all zones having 40 or more trips attracted for each of the three purpose groupings.

For the first set of equations, even though trips produced by only 14 zones were used, the attraction ends of the trips were distributed to a great many zones. For example, assume that 10,000 trips of a given purpose were produced by the 14 zones and of these, say, 200 were attracted to Zone 1, 300 to Zone 4, 1,000 to Zone I2, 2,000 to Zone 20, 1,500 to Zone 50, etc. The ${ }^{2}$ total of all trips attracted would be 10,000. The trips attracted to each zone were divided by 10,000 , the total of trips produced, giving a proportion 
F IGURE 5

COMPARISON OF TRIF LENGTH FREOUENCY USING O-D DATA

HOME-WORK. TRIPS

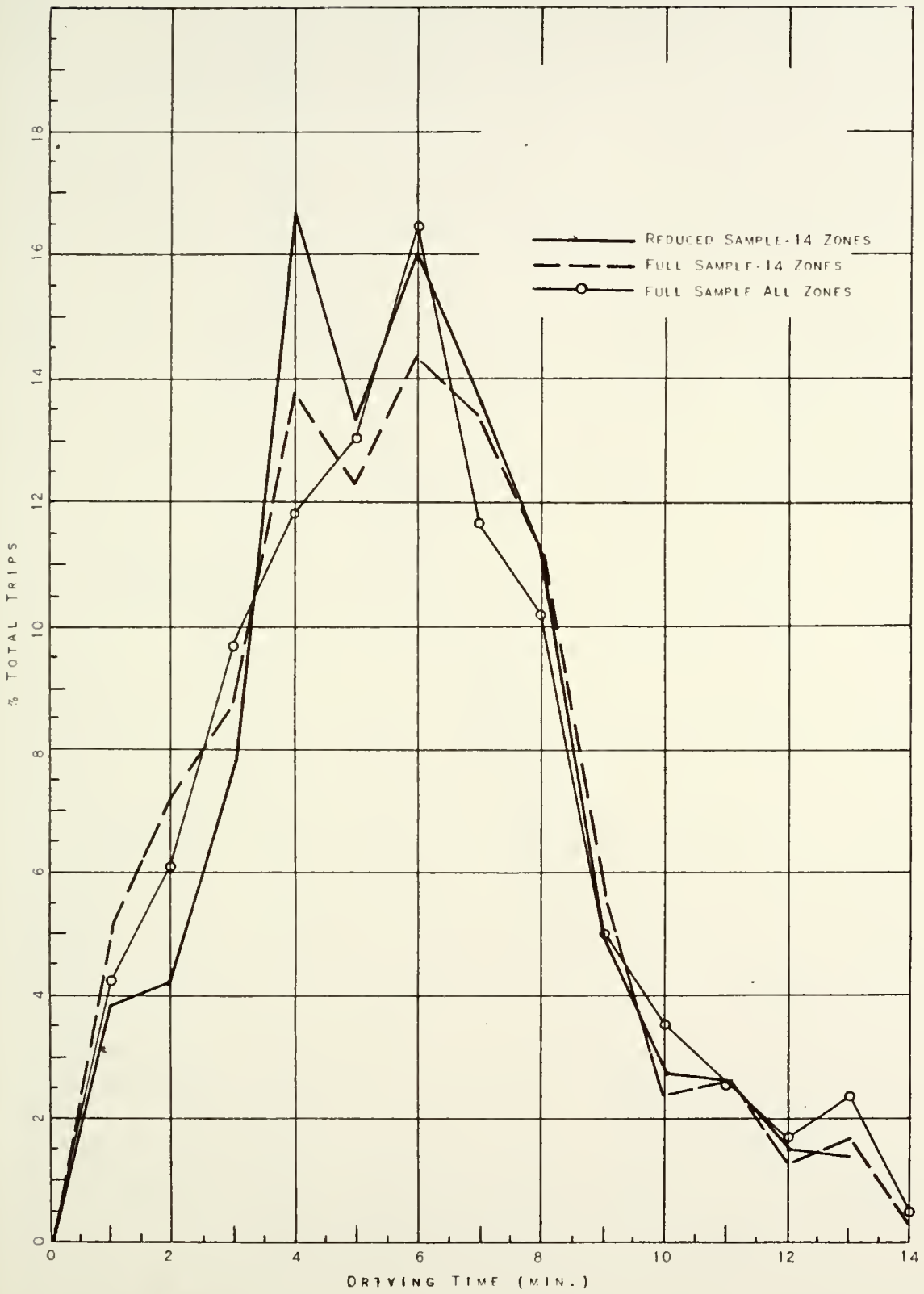


FIGURE 6

COMPARISON OF TRIP LENGTH FREQUENCY USING O-D DATA

HOME-OTHER TRIPS

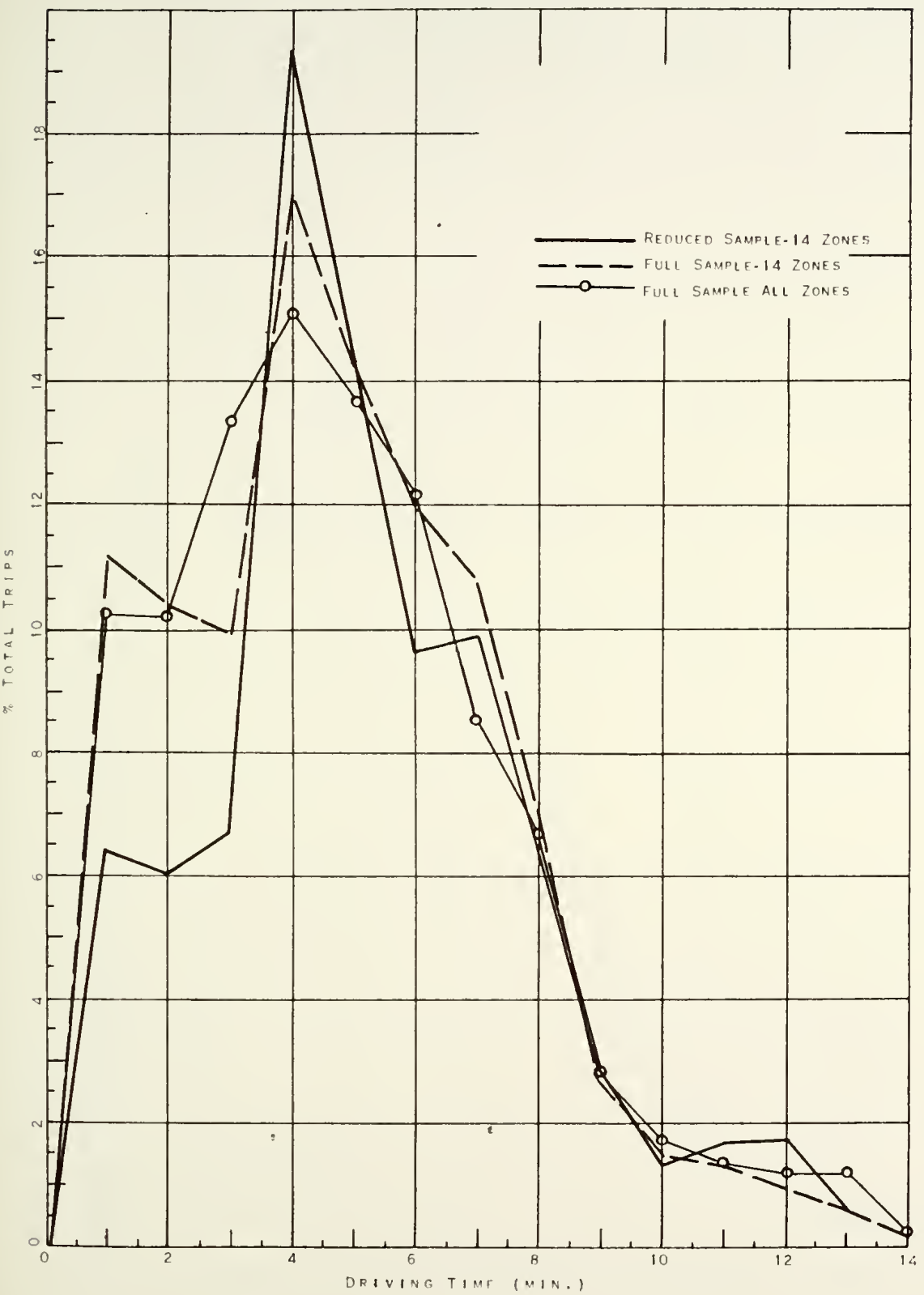


FIGURE \%

COMPARISON OF TRIP LENGTH FREQUENCY USING O-D DATA NON-HOME TRIPS

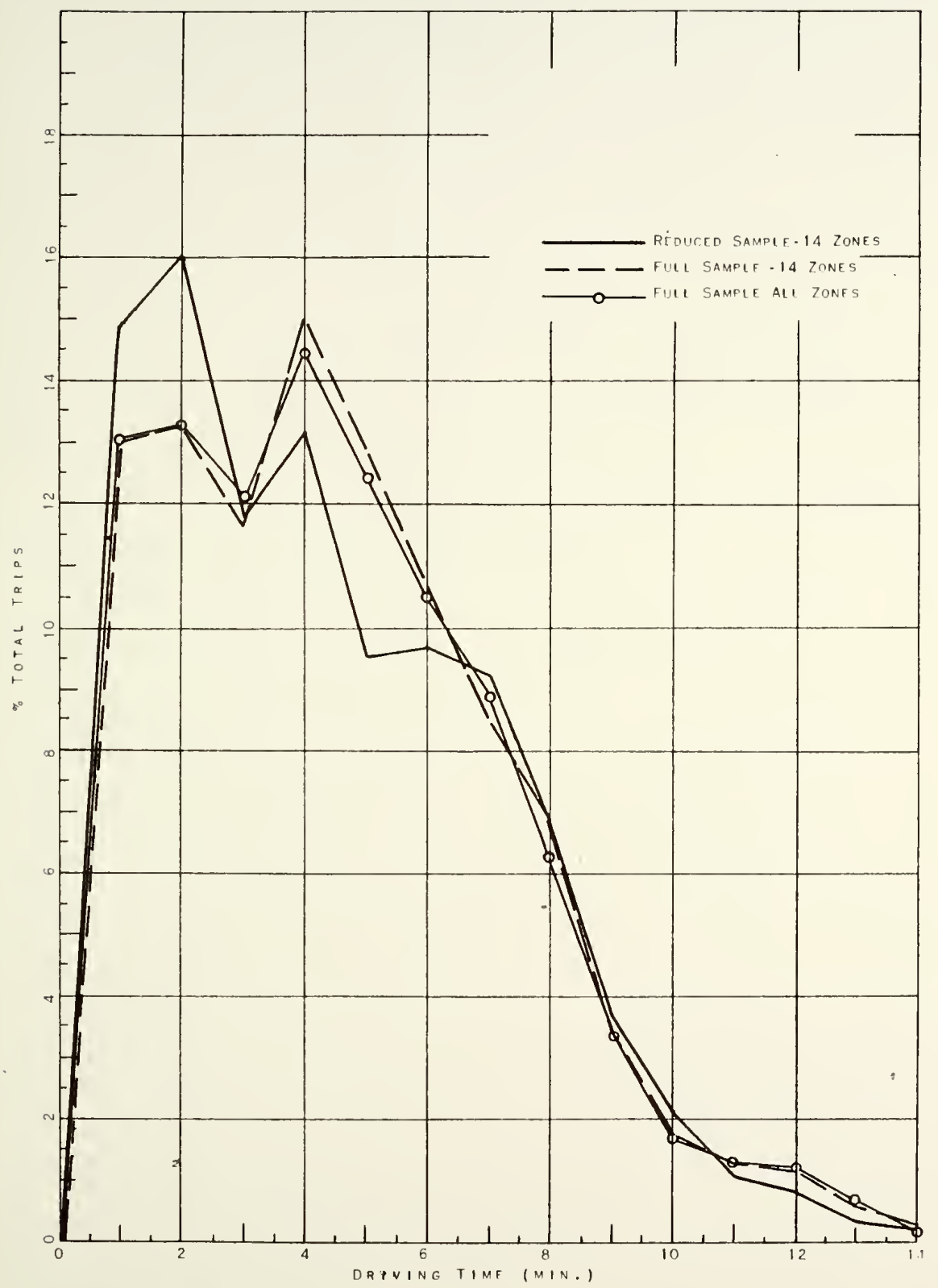


of all trips attracted to a given zone. Thus Zone 1 would have 0.02 trips attracted per trip produced, Zone 4 would attract 0.03 , Zone 12 would attract 0.10 , Zone 20 would attract 0.20 and Zone 50 would attract 0.15 trips per trip produced.

Based upon such zonal characteristics as various types of land use in 1000's of square feet, numbers of jobs of various classifications and total number of persons and dwelling units in the zone, an equation was developed for each trip purpose that estimated the trip attractions in the various zones. The dependent variable was the number of trips attracted per trip produced.

A similar procedure was followed in developing equations based upon the 20 per cent sample obtained in the O-D survey.

The estimating equation for the non-home productions was developed in the same manner as that for trip attractions.

In the case of home-work attractions, it was discovered that the best predictor of trips attracted was the total employment in a zone. Since the "SCRAP" program would not handle a problem with a single independent variable, the equation was developed using a computer program which fitted a polynomial to the data by the method of least squares.

The equation for trip attractions, along with non-home productions, had to be multiplied by the total number of trips produced in the study area in order to give total attractions per zone. Thus, zonal estimates of trip attractions (and non-home productions) were the product of two estimates and in general were less satisfactory than estimates of home-based productions. 
In the development of the estimating equations using the "SCRAP" program it was necessary, in each case, to try various relationships among the independent variables. In general, a linear relationship was first tried, followed by more complex equations. The output from each run was examined and those variables were deleted that resulted in a relatively low loss in sum-of-squares when the deletion was made. This rather crude method of selection of variables worked well enough but may also have been partially responsible for the large number of runs on the computer that were necessary to obtain the equations that were judged to be satisfactory.

\section{The Development of Travel Time Factors}

The calibration of the gravity model (Equation A, page 8) was carried out using the three trip purposes: home-work, home-other and non-home. The calibration consisted principally of the determination of travel time factors which resulted in a trip length frequency distribution which satisfactorily compared with the trip length frequency distribution of the surveyed population.

Two sets of travel time factors for each trip purpose were. determined. One set was determined using zonal productions and attractions from the comprehensive $O-D$ survey while zonal productions and attractions obtained from the reduced sample size in the 14 selected zones were used for the second set of travel time factors.

The gravity model formula as used requires input parameters of zonal trip productions, attractions, travel time factors and zone- 
to-zone adjustment factors (see page 8). The zone-to-zone adjustment factors were used as unity throughout this study because of no apparent effect on travel patterns of defined zonal characteristics.

The travel times used for determination of the corresponding travel time factors for use in the gravity model were made up of - the terminal time on each end of the trip plus the zone to zone driving time. The zone to zone minimum driving time was obtained from the "time trees" which were developed from travel-time study data. The driving time for intrazonal trips (those trips with both ends in a given zone) was not available from the time trees and was estimated at one minute for each zone. The intrazonal time was chosen after inspection of interzonal times for all adjacent zones. The interzonal times of adjacent zones were, in all cases, slightly less than two minutes. The maximum intrazonal time was also about two minutes and a reasonable average time was believed to be one minute. Reference (1) discusses other methods of determining intrazonal times. The terminal time of one end of a trip may be made up of the time spent in cruising for a parking space, the time spent waiting before a vehicle can be parked and the time spent walking from the parking place to the actual destination. The terminal time of the other end of the trip may consist of the time spent walking from home to garage or parking lot and the time from garage or parking lot onto the street system. The terminal times for the zones in Hutchinson were estimated, initially, after consultation with personnel who were familiar with Hutchinson. The CBD, Zones 12, 13 and 50 (Figure 1), were each given terminal times of three 
minutes and each of the zones adjacent to the CBD was given a terminal time of two and one-half minutes with each of the remaining zones being given a terminal time of one and one-half minutes. It was found that some changes in these terminal times resulted in better trip end balance for some zones and some trip purposes. Table 12 shows the final sets of terminal times used in the study. The interzonal travel time between any two zones was made up of the terminal time of the production zone plus the driving time between the zones plus the terminal time of the attraction zone.

Intrazonal travel time for a given zone was made up of twice the zonal terminal time plus the intrazonal driving time for that zone.

A set of travel time factors using the comprehensive $\mathrm{O}-\mathrm{D}$ zonal productions and attractions was developed as follows: An initial set of travel time factors was assumed and the trip interchanges between all zones were computed. The trip length frequency distribution of the trip interchanges was determined by finding the number and the percentage of trips falling in each one minute increment of driving time. The estimated trip length frequency was then compared with the actual trip length frequency distribution obtained from the $\mathrm{O}-\mathrm{D}$ data. The comparison was made in three ways: First, both distributions expressed as per cent trips for each one minute driving time should, when plotted, be relatively close to one another; second, the average trip length, in minutes, for both sets of data should be within \pm 5 per cent of each other; and, third, the person hours of travel for both sets of data should be within \pm 5 per cent 
TABLE 12

FINAL TERMINAL TIMES BY ZONE AND TRIP PURPOSE

\begin{tabular}{|c|c|c|c|}
\hline \multirow{2}{*}{$\begin{array}{l}\text { Terminal } \\
\text { Time } \\
\text { (Min.) }\end{array}$} & \multicolumn{3}{|c|}{ Trip Purpose } \\
\hline & Home-Work & Home - Other & Non - Home \\
\hline 3.0 & * $12,13,50$ & (None) & $12,13,50$ \\
\hline 2.5 & $\begin{array}{l}\text { ** } \\
14,15,16,17,18,51 \\
52,53\end{array}$ & (None) & $\begin{array}{l}14,15,16,17,18,51, \\
52,53\end{array}$ \\
\hline 2.0 & $19,58,59,60,61,63$ & $\begin{array}{l}12,13,14,15,16,17, \\
18,19,50,51,62,53, \\
58,59,60,61,63\end{array}$ & $19,58,59,60,61,63$ \\
\hline 1.5 & All Others & All Others & All Others \\
\hline
\end{tabular}

* CBD zones

* Adjacent zones to CBD

* * Other highly developed zones

*** Relatively undeveloped zones 
of each other (1). The average trip length was determined by multiplying the number of trips of each incremental trip length by the length of trip (driving time) in minutes and dividing this product by the total number of trips.

The vehicle hours of travel were obtained by multiplying the number of trips of each incremental trip length by the length of trip in minutes and dividing the product by 60 .

Computer programs* were written to determine the trip length distributions as well as the average trip length and vehicle hours of travel.

If the comparisons were not within the limits cited above, then an adjustment was made in the initially assumed set of travel time factors for each trip purpose. The travel time factors were adjusted manually by a procedure which follows from the question: "What must be done to the travel time factor at each travel time increment to bring the gravity model estimated percentage of trips, in each travel time increment, into closer agreement with the surveyed trips at each increment?" The actual adjustment was made for each travel time increment by multiplying the initial travel time factor for each increment by the ratio of the percentage of surveyed trips to the percentage of estimated trips for the respective time increments. The adjusted travel time factors (for each one minute of travel time) were then plotted against the respective travel time increments on log-log graph paper in most cases and straight-line graph paper in others. The second set of travel time factors was 
then determined from a hand-fitted line of best fit to the adjusted factors. The gravity model was then run using the second set of travel time factors and the comparisons of trip length frequency, etc. were repeated. This process was continued until satisfactory agreement among the comparisons was reached.

In the case of home-work trips 12 sets of adjustments were required before acceptable agreement was reached. Better estimates of initial travel time factors would have resulted in fewer iterations being required. This was graphically illustrated in the case of home-other trips when the lowa travel time factors $(9,16)$ shown in Table 13 were used for the initially estimated factors and required only four iterations. In addition, much time was spent in adjusting to the trip length frequency curve. The researcher is of the opinion that if two-minute increments of travel time had been used satisfactory results would have been obtained much more quickly.

The second set of travel time factors was developed in a manner similar to that explained above with the exception that productions and attractions obtained from data from the 14 zones with the reduced sample size were used. The trip length frequency, average trip length and vehicle hours of travel, against which comparisons were made, were those resulting from the $O-D$ data obtained from the reduced sample size in the 14 zones. The Iowa travel time factors $(9,16)$ were used as the first estimate of the factors used for each trip purpose. From three to seven iterations were necessary to arrive at acceptable factors. The computer time was much reduced because of the great reduction in number of trips to be distributed. 
TABLE 13

CEDAR RAPIDS (IOWA) TRAVEL TIME FACTORS*

\begin{tabular}{|c|c|c|c|c|c|c|c|}
\hline \multirow{2}{*}{$\begin{array}{c}\text { Travel } \\
\text { Time } \\
\text { (Min.) }\end{array}$} & \multicolumn{3}{|c|}{$\begin{array}{l}\text { Travel Time Factors } \\
\text { by Purpose }\end{array}$} & \multirow{2}{*}{$\begin{array}{c}\text { Travel } \\
\text { Time } \\
\text { (Min.) }\end{array}$} & \multicolumn{3}{|c|}{$\begin{array}{c}\text { Travel Time Factors } \\
\text { by Purpose }\end{array}$} \\
\hline & Work & $\begin{array}{l}\text { Non Home } \\
\text { Based }\end{array}$ & $\begin{array}{c}\text { Other Home } \\
\text { Based }\end{array}$ & & Work & $\begin{array}{c}\text { Non Home } \\
\text { Based }\end{array}$ & $\begin{array}{c}\text { Other Home } \\
\text { Based }\end{array}$ \\
\hline 1 & 2.00 & 3.00 & 5.00 & 28 & 0.33 & 0.07 & 0.10 \\
\hline 2 & 2.00 & 2.25 & 3.66 & 29 & 0.31 & 0.06 & 0.09 \\
\hline 3 & 2.00 & 1.80 & 2.20 & 30 & 0.29 & 0.05 & 0.08 \\
\hline 4 & 1.50 & 1.40 & 1.45 & 31 & 0.27 & 0.04 & 0.06 \\
\hline 5 & 1.25 & 1.15 & 1.20 & 32 & 0.25 & 0.03 & 0.04 \\
\hline 6 & 1.10 & 1.00 & 1.00 & 33 & 0.23 & 0.02 & 0.03 \\
\hline 7 & 1.00 & 0.90 & 0.90 & 34 & 0.21 & 0.01 & 0.02 \\
\hline 8 & 0.93 & 0.80 & 0.80 & 35 & 0.19 & 0.01 & 0.01 \\
\hline 9 & 0.87 & 0.70 & 0.70 & 36 & 0.17 & & \\
\hline 10 & 0.84 & 0.62 & 0.62 & 37 & 0.15 & & \\
\hline 11 & 0.80 & 0.56 & 0.56 & 38 & 0.14 & & \\
\hline 12 & 0.76 & 0.49 & 0.50 & 39 & 0.13 & & \\
\hline 13 & 0.72 & 0.43 & 0.45 & 40 & 0.12 & & \\
\hline 14 & 0.68 & 0.38 & 0.41 & 41 & 0.11 & & \\
\hline 15 & 0.64 & 0.34 & 0.38 & 42 & 0.10 & & \\
\hline 16 & 0.61 & 0.30 & 0.35 & 43 & 0.09 & & \\
\hline 17 & 0.58 & 0.27 & 0.32 & 44 & 0.08 & & \\
\hline 18 & 0.55 & 0.24 & 0.30 & 45 & 0.07 & & \\
\hline 19 & 0.52 & 0.22 & 0.27 & 46 & 0.06 & & \\
\hline 20 & 0.49 & 0.20 & 0.25 & 47 & 0.05 & & \\
\hline 21 & 0.47 & 0.18 & 0.23 & 48 & 0.04 & & \\
\hline 22 & 0.45 & 0.16 & 0.21 & 49 & 0.04 & & \\
\hline 23 & 0.43 & 0.14 & 0.19 & 50 & 0.04 & & \\
\hline 24 & 0.41 & 0.12 & 0.17 & 51 & 0.03 & & \\
\hline 25 & 0.39 & 0.10 & 0.15 & 52 & 0.03 & & \\
\hline 26 & 0.37 & 0.09 & 0.13 & 53 & 0.02 & & \\
\hline 27 & 0.35 & 0.08 & 0.11 & & & & \\
\hline
\end{tabular}

*Source: Ref. (9, 16) 
Figures 8,9 , and 10 show the comparison of trip length distributions as obtained for the 14 zone, reduced sample O-D data versus the model distribution using the second set of travel time factors.

Table 14 shows the best set of travel time factors developed in each case.

Figures II, 12 and 13 show a graphical comparison of travel time factors developed.

The trip length frequency data were developed on the basis of driving time rather than travel time. An examination of the computational procedures indicates that with little difficulty the distribution could have been made on the basis of travel time, provided that terminal times were introduced as input data. 
FIGURE 8

COMPARISON OF TRIP LENGTH FREQUENICY USING O-D AND MODEL DATA HOME-WORK TRIPS

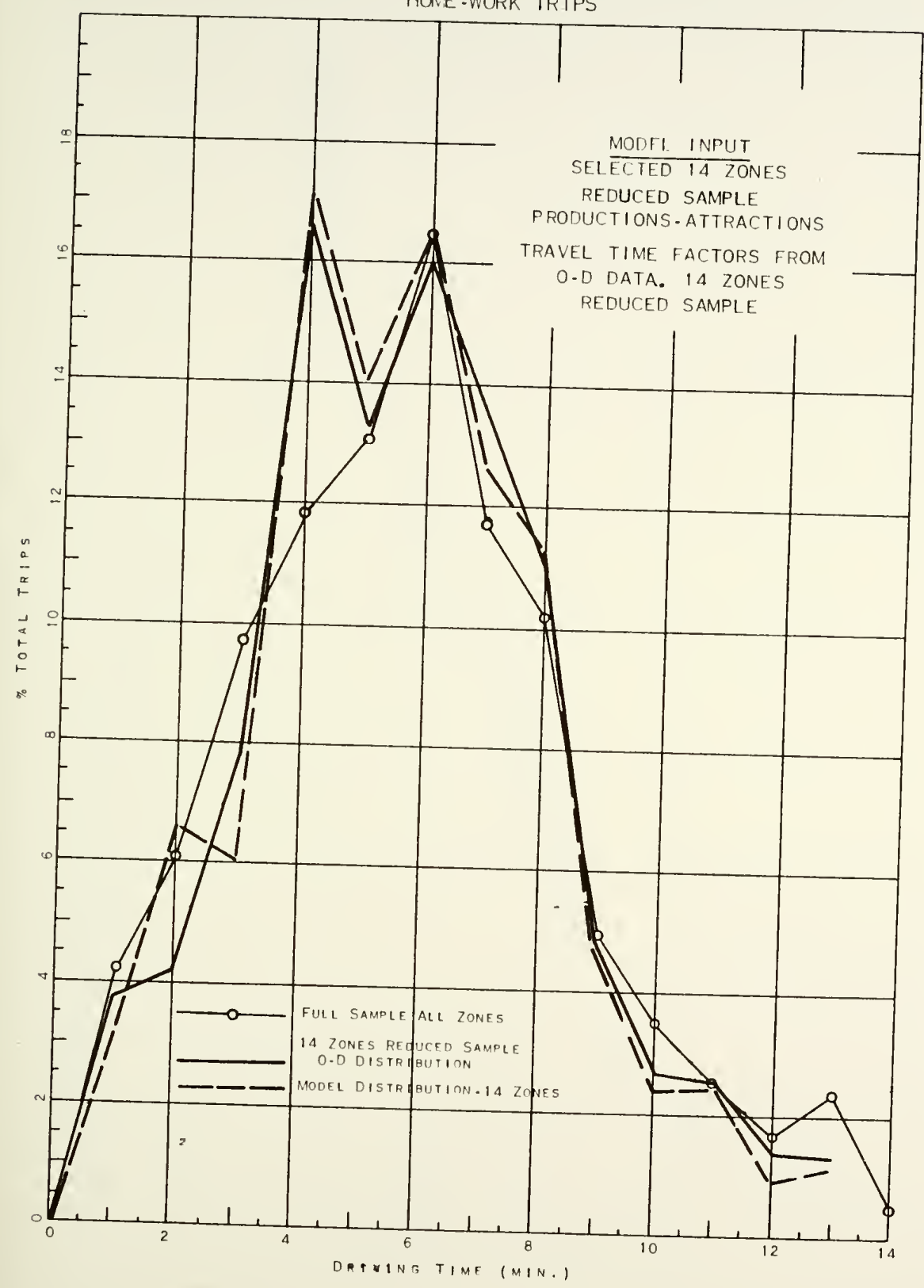


FIGURE 9

COMPARISON OF TRIP LENGTH FREQUENCY USING O-D AND MODEL DATA

HOME-OTHER TRIPS

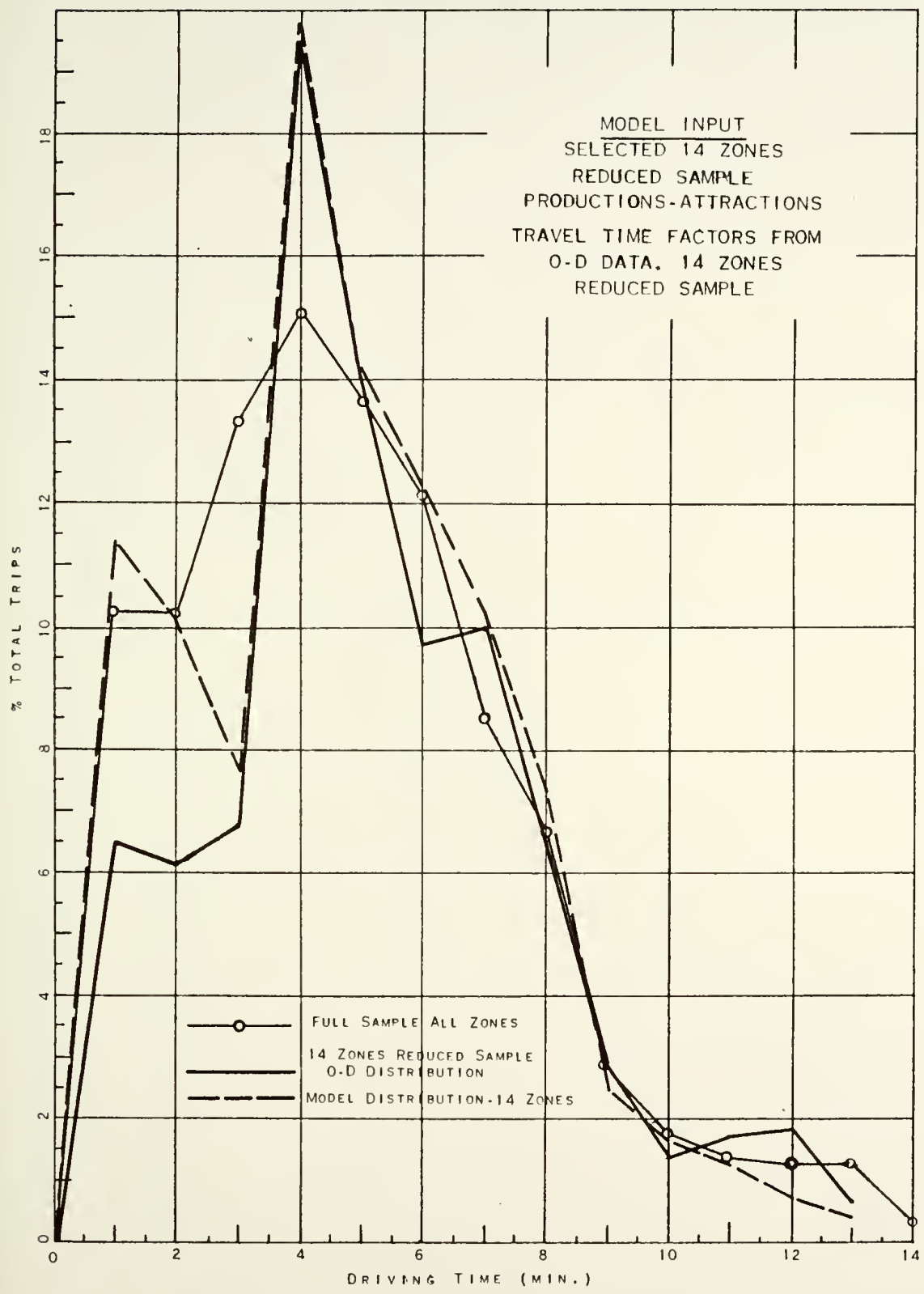


FIGURE 10

COMPARISON OF TRIP LENGTH FREQUENCY USING O-D AND MODEL DATA NON-HOME TRIPS

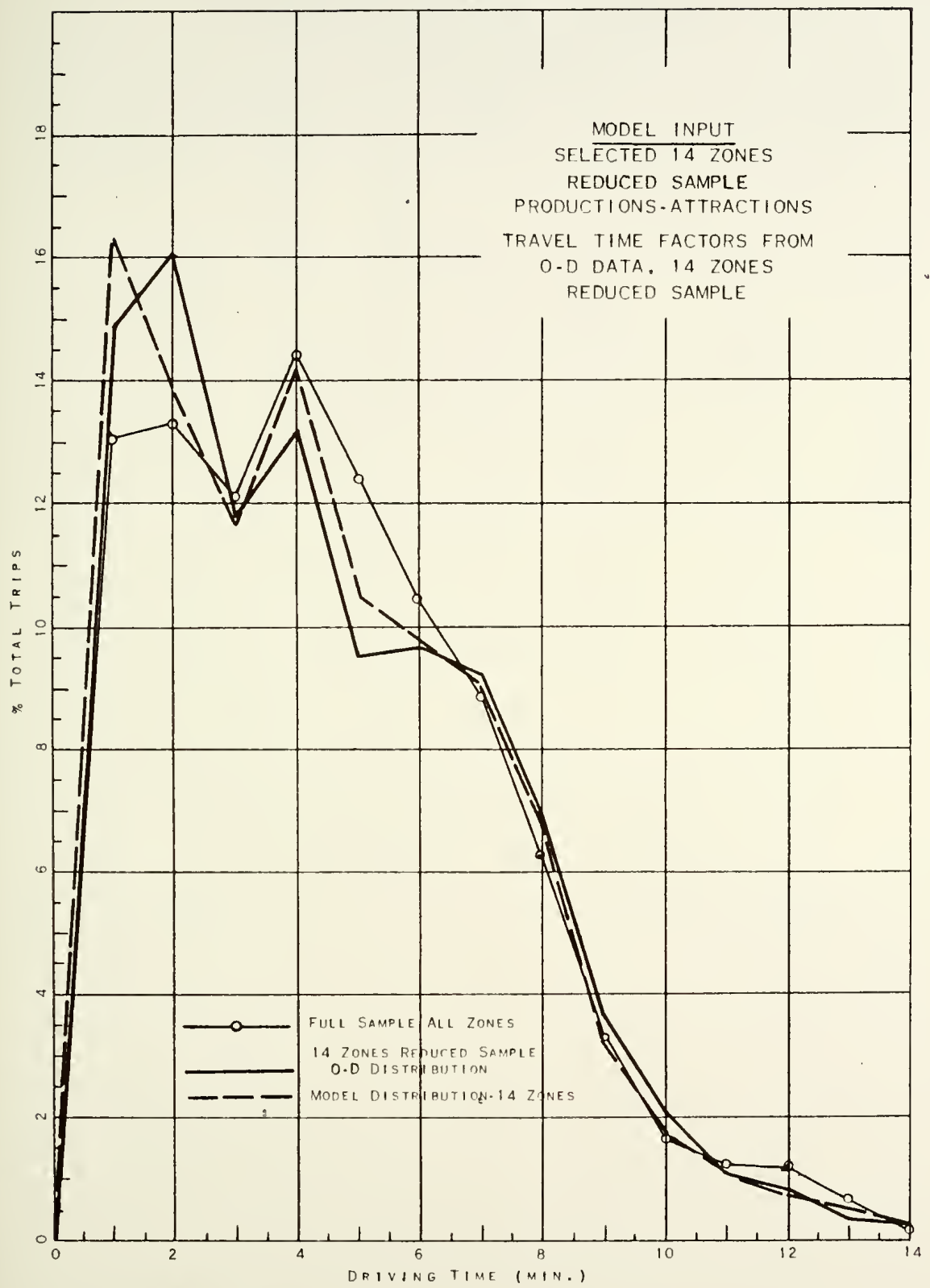


TABLE 14

TRAVEL TIME FACTORS BY TRIP PURPOSE

\begin{tabular}{|c||c|c|c|c|c|c|}
\hline \multirow{2}{*}{$\begin{array}{c}\text { Trave } \\
\text { Time } \\
\text { (Min.) }\end{array}$} & \multicolumn{7}{|c|}{ Travel Time Factors } \\
\cline { 2 - 7 } & F.S.* & R.S.** & F.S.* & R.S.** & F.S.* & R.S. ** \\
\hline & & & & & & \\
& & & & & & \\
& & & & & & \\
4 & 2.78 & 2.12 & 1.74 & 2.70 & 1.40 & 3.00 \\
5 & 2.40 & 1.70 & 1.22 & 1.84 & 1.15 & 2.25 \\
6 & 2.20 & 1.41 & .94 & 1.23 & 1.00 & 1.80 \\
7 & 1.97 & 1.20 & .78 & .91 & .90 & 1.40 \\
8 & 1.78 & 1.06 & .65 & .68 & .80 & 1.15 \\
9 & 1.58 & .93 & .56 & .51 & .70 & 1.00 \\
10 & 1.43 & .84 & .49 & .41 & .62 & .90 \\
11 & 1.32 & .76 & .43 & .34 & .56 & .80 \\
12 & 1.20 & .70 & .39 & .28 & .49 & .70 \\
13 & 1.12 & .65 & .35 & .23 & .43 & .62 \\
14 & 1.04 & .60 & .32 & .19 & .38 & .56 \\
15 & .96 & .56 & .30 & .17 & .34 & .49 \\
16 & .90 & .53 & .28 & .14 & .30 & .43 \\
17 & .85 & .49 & .25 & .12 & .27 & .38 \\
18 & .80 & .46 & .23 & .11 & .24 & .34 \\
19 & .76 & .44 & .21 & .10 & .22 & .30 \\
20 & .72 & .43 & .20 & .09 & .20 & .27 \\
\hline
\end{tabular}

* F.S. - Model Input: Full Sample O-D Productions-Attractions, All zones

* R.S. - Model Input: Reduced Sample O-D Productions-Attractions, 14 zones

Note: No travel time of less than four $(4)$ minutes was possible for any trip. 


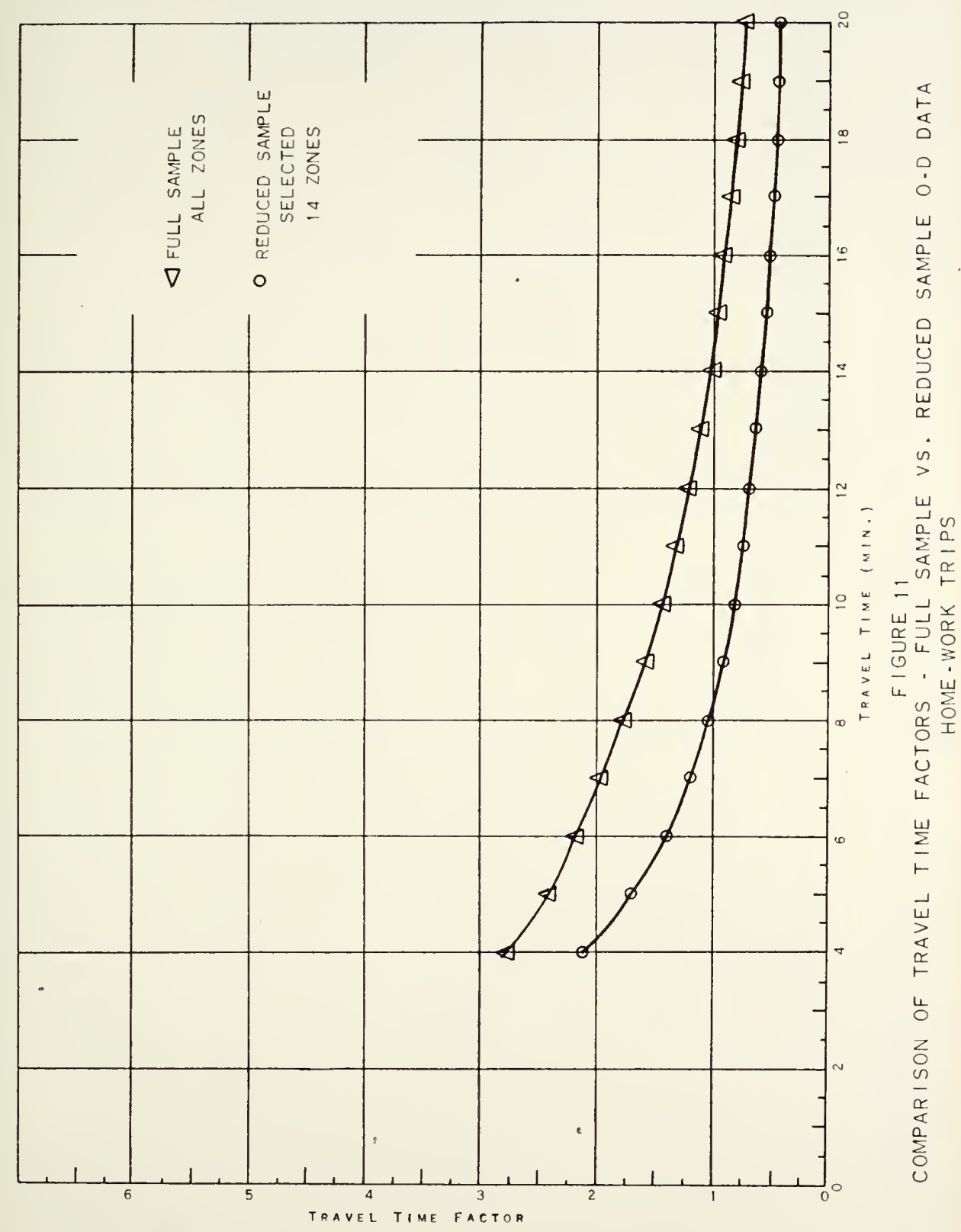




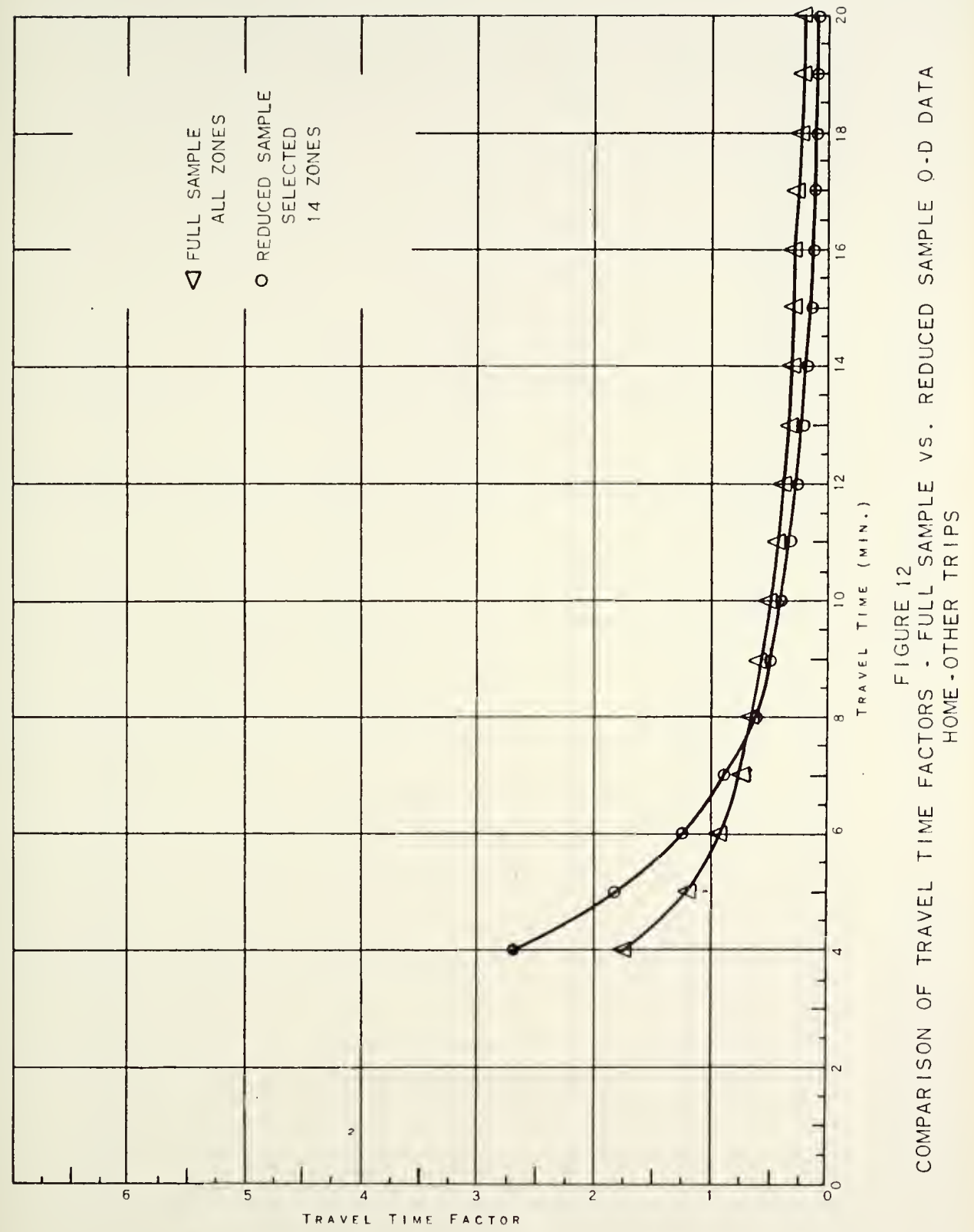




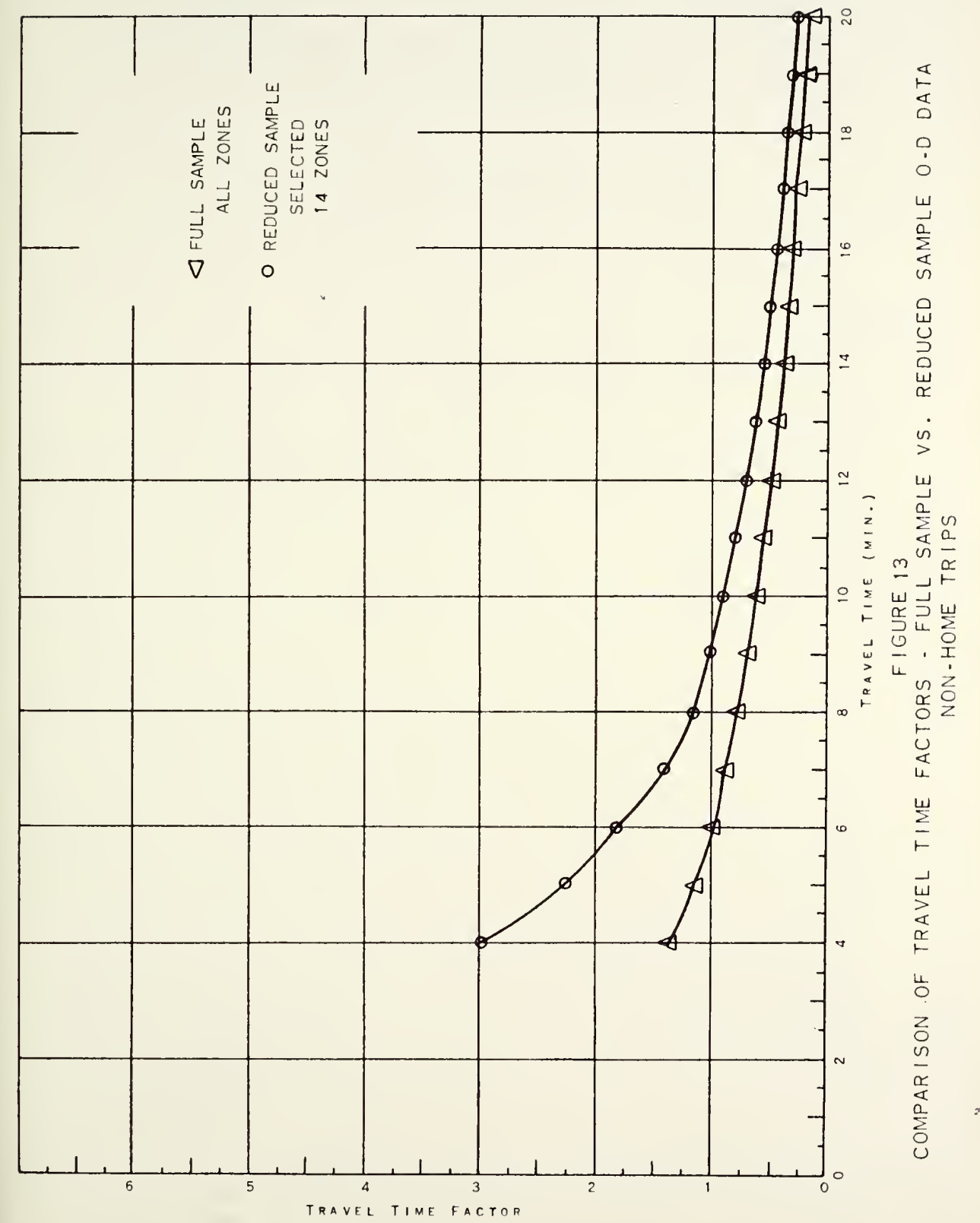


ANALYSIS OF RESULTS

\section{Estimates of Trip Production and Attraction}

The estimating equations for trip productions and attractions as developed using the regression analysis technique are shown in Tables 15 and 16. The coefficients of correlation, as obtained from the "SCRAP" regression analysis program are shown in Table 17.

The squared correlation coefficient or coefficient of determination, $R^{2}$, is a measure of the amount of variation about the mean that the estimating equation explains. It was found, however, that although many of the $R^{2}$ values were quite high, that this coefficient did not necessarily indicate the predictive power of the various equations. For the same data, however, higher values of $\mathrm{R}^{2}$ did indicate better predictive power of the form of equation being used.

A more meaningful statistical test of the estimating power of the equations was felt to be the calculation of root-mean-square (RMS) errors. The RMS error for each equation was computed by summing the squares of the differences between the estimated and surveyed values of production or attraction and dividing the total squared differences by the number of zoned productions or attractions and finding the square root of the quotient. 


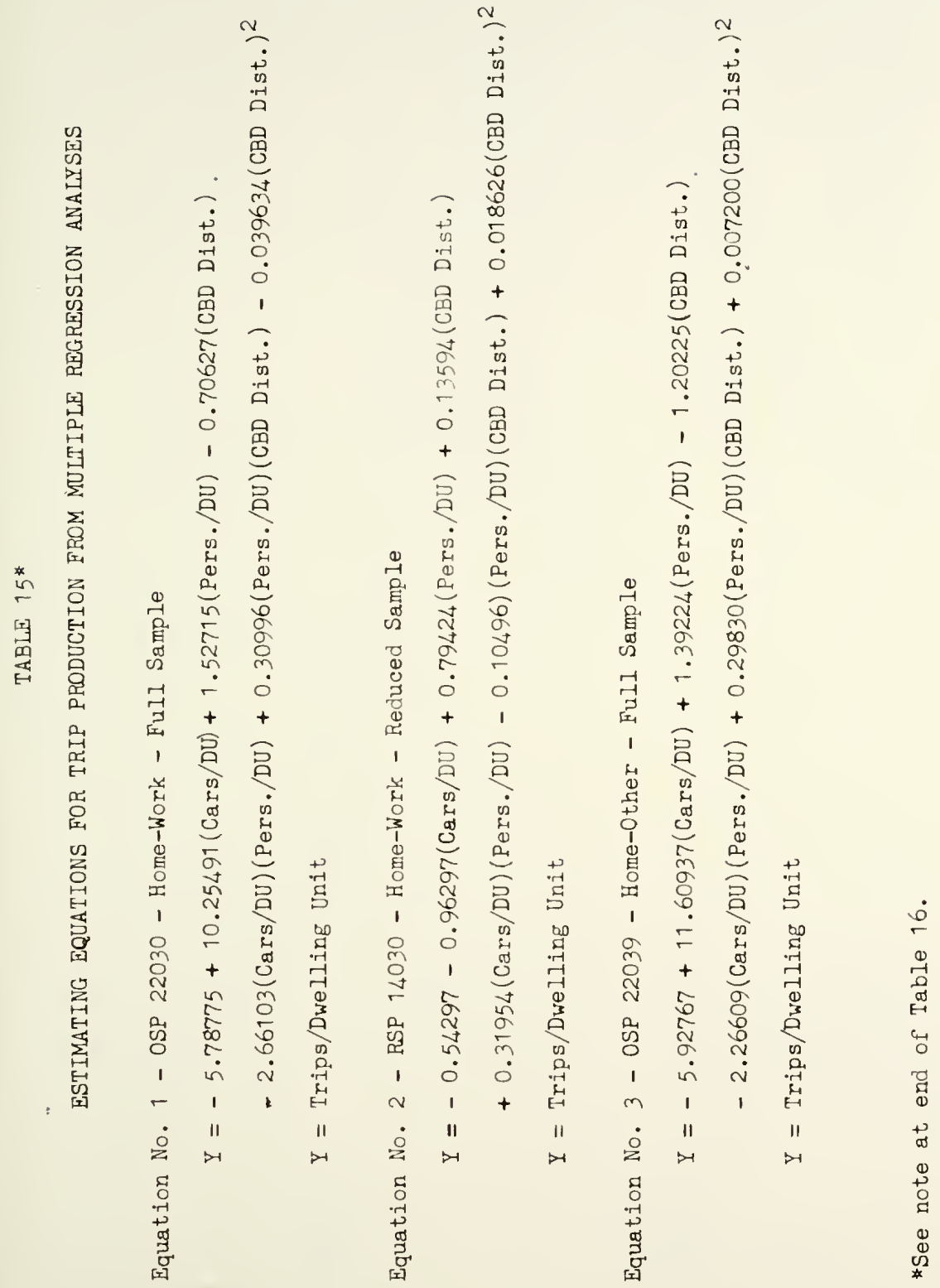




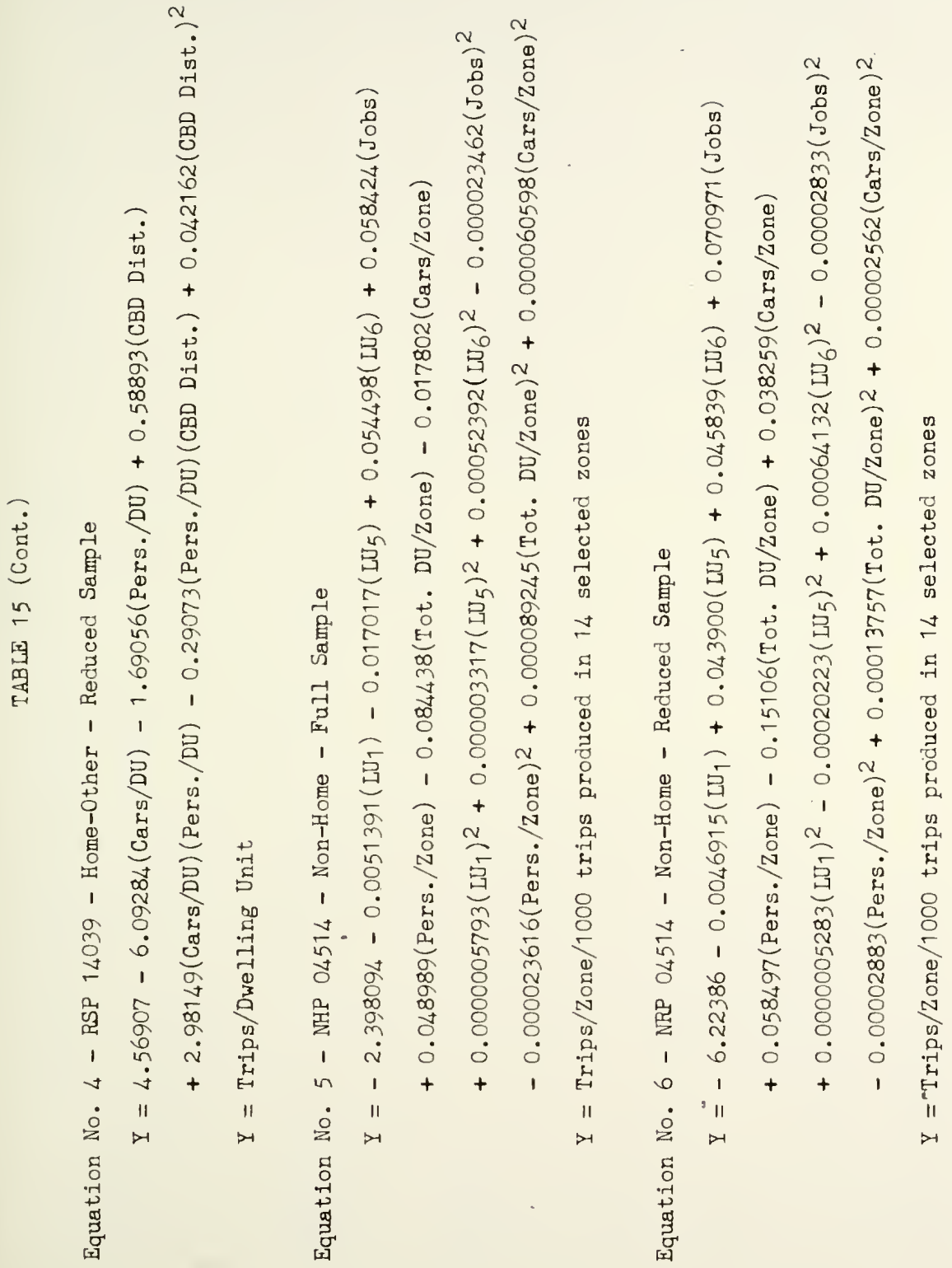


㾞

ż

点

息

旓

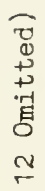

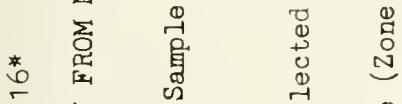

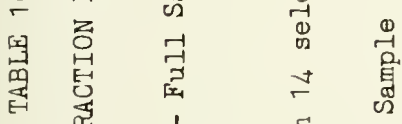

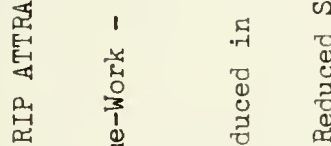

도언

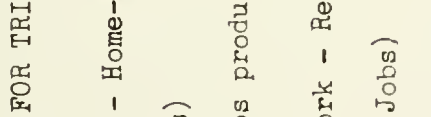

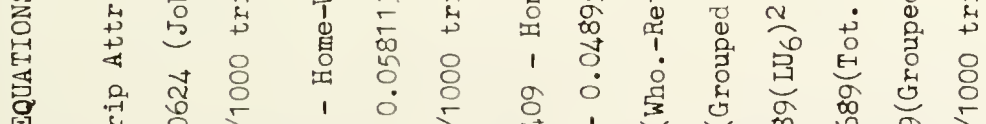

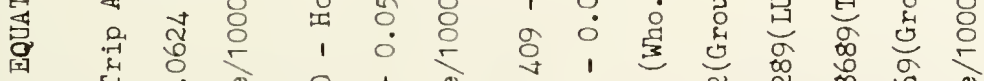

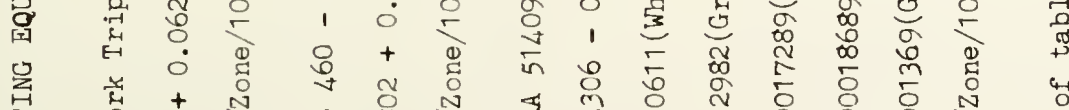

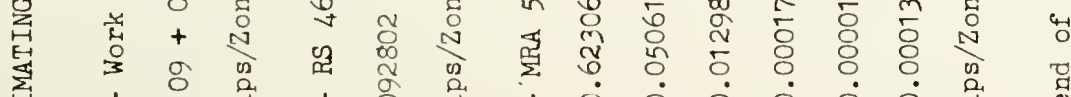
泉 1 ○

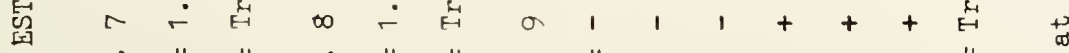

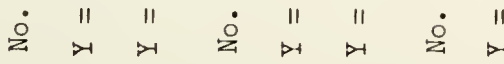

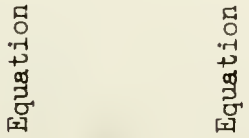

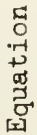




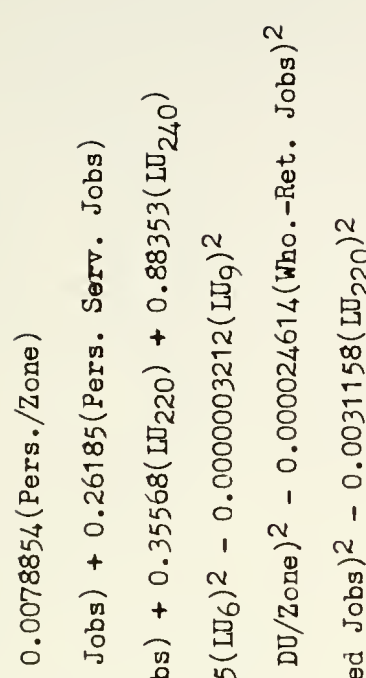

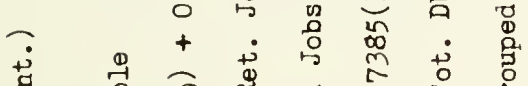

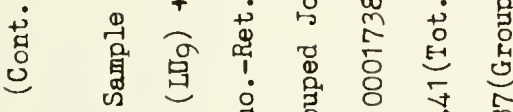

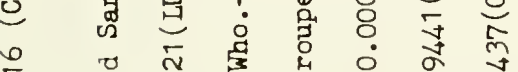

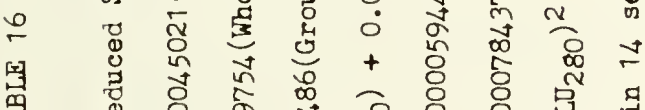

舀

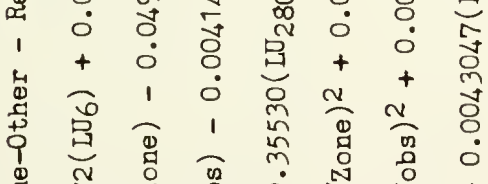

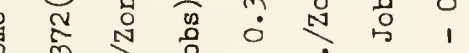

, 品号

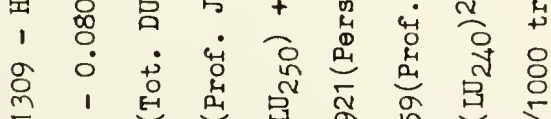

元 1 ज

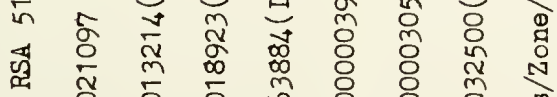

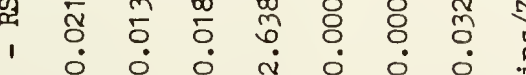

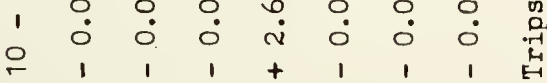

i 11

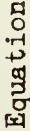

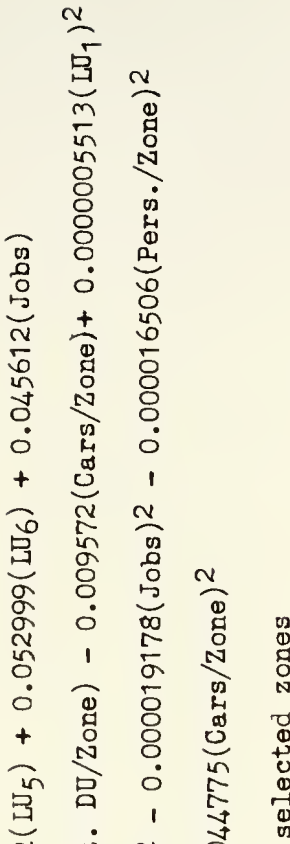

ก 少 $匚$ 是 0 .

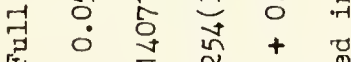

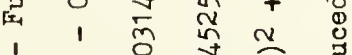

音

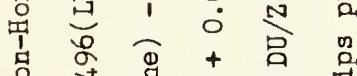
范

$\checkmark \quad 0 \quad$ 量 $\mathrm{O}$

₹ 1 क ज है ठ

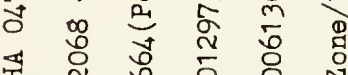

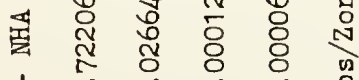
$1 \quad 0 \quad 0000000$ $=1+++{ }_{E-1}$ 일 


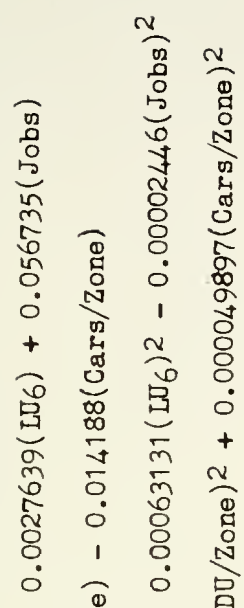

\begin{tabular}{l}
0 \\
0 \\
0 \\
0 \\
N \\
\hline
\end{tabular}

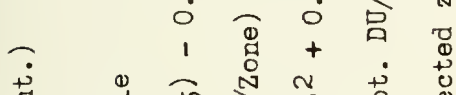

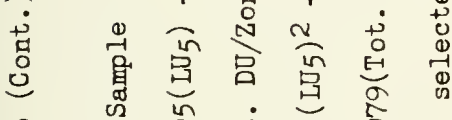

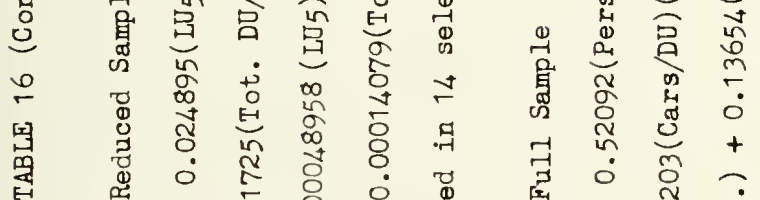

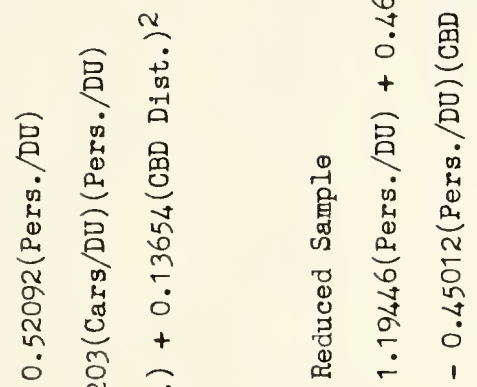

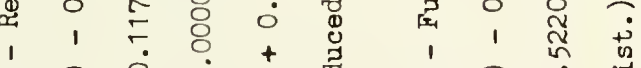

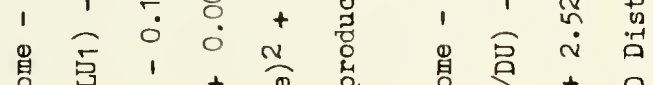

界孚

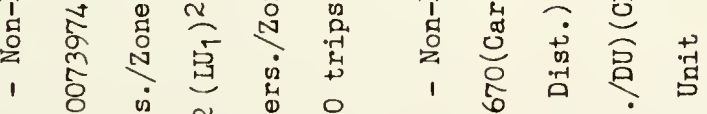

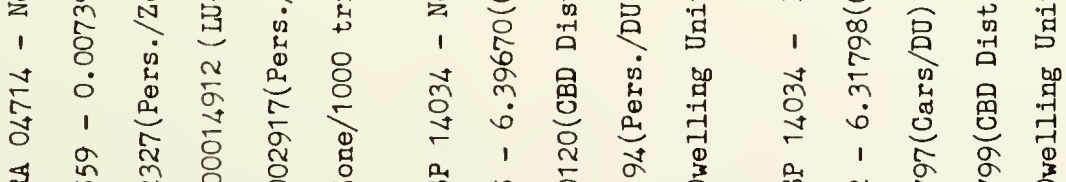

䍃

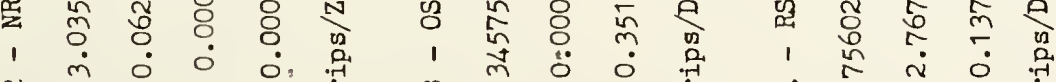

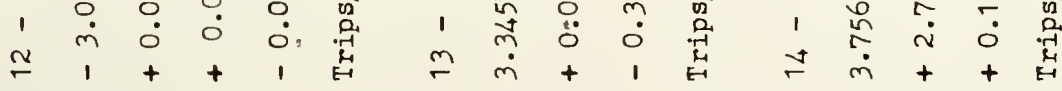

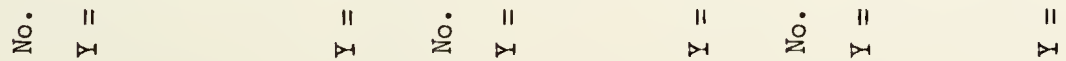

व

孚

명 


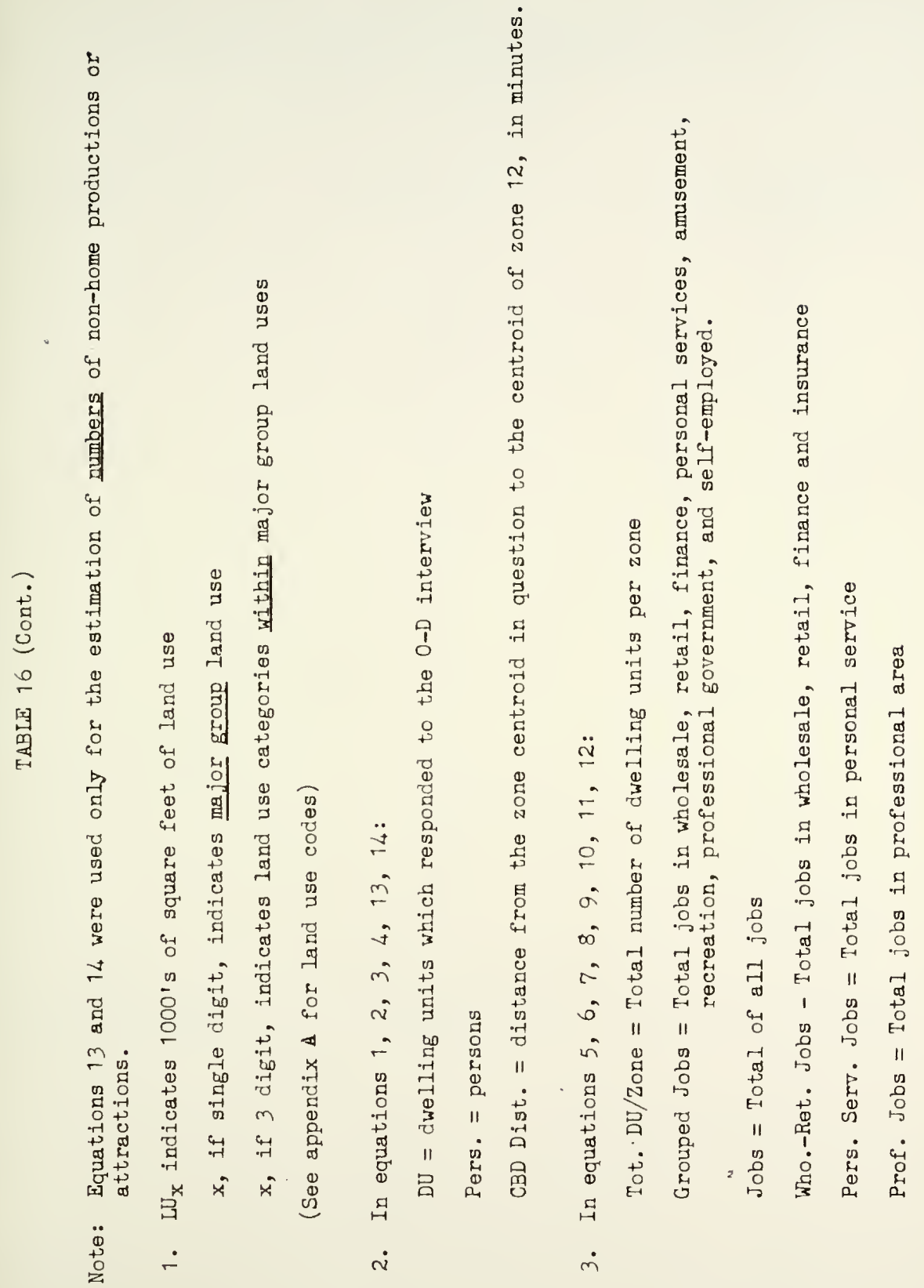


TABLE 17

\section{COEFFICIENTS OF CORRELATION AND DETERMINATION \\ FROM REGRESSION ANALYSIS}

\section{Equation $\angle 1$}

1

2

3

4

5

6

7

8

9

10

11

12

13

14
Coefficlent of

Correlation R

.936

.952

.918

.912

.995

.991

$\angle 2$

$\angle 2$

.994

.992

.995

.986

.968

.961
Coefficient of Determination $\mathrm{R}^{2}$

.876

.907

.843

.831

.990

.982

$\angle 2$

$\angle 2$

.989

.984

.990

.972

.937

.923

$\angle 1$ See Table 15 or 16 for the form of the equation

$\angle 2$ Not determined, equation developed in "polynomial best fit" program. See Table 18 for RMS orror comparisons. 
The following equation was used for computing the RMS error:

$$
\text { RMS error }=\sqrt{\frac{(Y-Y \text { est }}{N}}
$$

Where

$$
\begin{aligned}
& \mathrm{Y}=\text { Surveyed value } \\
& \mathrm{Y}_{\text {est }}=\text { Value estimated from regression equation } \\
& \mathrm{N}=\text { Number of values. }
\end{aligned}
$$

The RMS error indicates the limits within which about two-thirds of the deviations between the observed and the estimated values will fall. The RMS errors, shown in Table 18, for the developed estimating equations were smallest, in each case, when the regression equation was based upon data obtained from the comprehensive O-D survey. The recorded RMS error, in most cases, appears to be reasonable when one considers that this is equivalent to stating that two-thirds of the time the estimated zonal productions or attractions can be expected to be within one RMS error of the actual value. The estimating power of equations $6,8,10$ and 12 were much improved when O-D survey productions were used to expand to zonal values. A plot of the estimated values versus $O-D$ values of zonal productions or attractions provided an excellent graphical portrayal of the "goodness of fit" of the estimating equations. Figures 14 through 25 show the comparison of $O-D$ trips per zone by purpose, to the estimated zonal trips as obtained from equations 1 through 12 . If the esti-" mated value was equal to the $O-D$ value, the plotted point fell on the "45" line". The plot of the "O-D value \pm RMS error" versus the O-D value would indicate a band within which one would expect the estimated values to fall about $2 / 3$ of the time. 
TABLE 18

RMS ERRORS OF ESTIMATING EQUATIONS

Equation $/ 1$

1

2

3

4

5

$6 \angle 2$

$6^{\angle 3}$

7

${ }_{8} \angle 2$

9

$10 \angle 2$

11

$12 \angle 2$

$12 \angle 3$
Average Trips

per Zone

302

297

545

545

306

306

307

219

219

452

411

297

306

306
RMS Error

65

118

137

171

71

218

146

39

88

208

208

65

220

162
\% RMS

Error $\angle 4$

21

40

25

31

23

71

48

18

40

51

51

22

72

53

$\angle 1$ See Table 15 or 16 for the form of the equation

$\angle 2$ Using estimated total non-home productions to expand to zonal totals

$\angle 3$ Using O-D total non-home productions to expand to zonal totals

$\angle 4 \%$ RMS error $=100$ (RMS error)/average trips per zone 
FIGURE 14

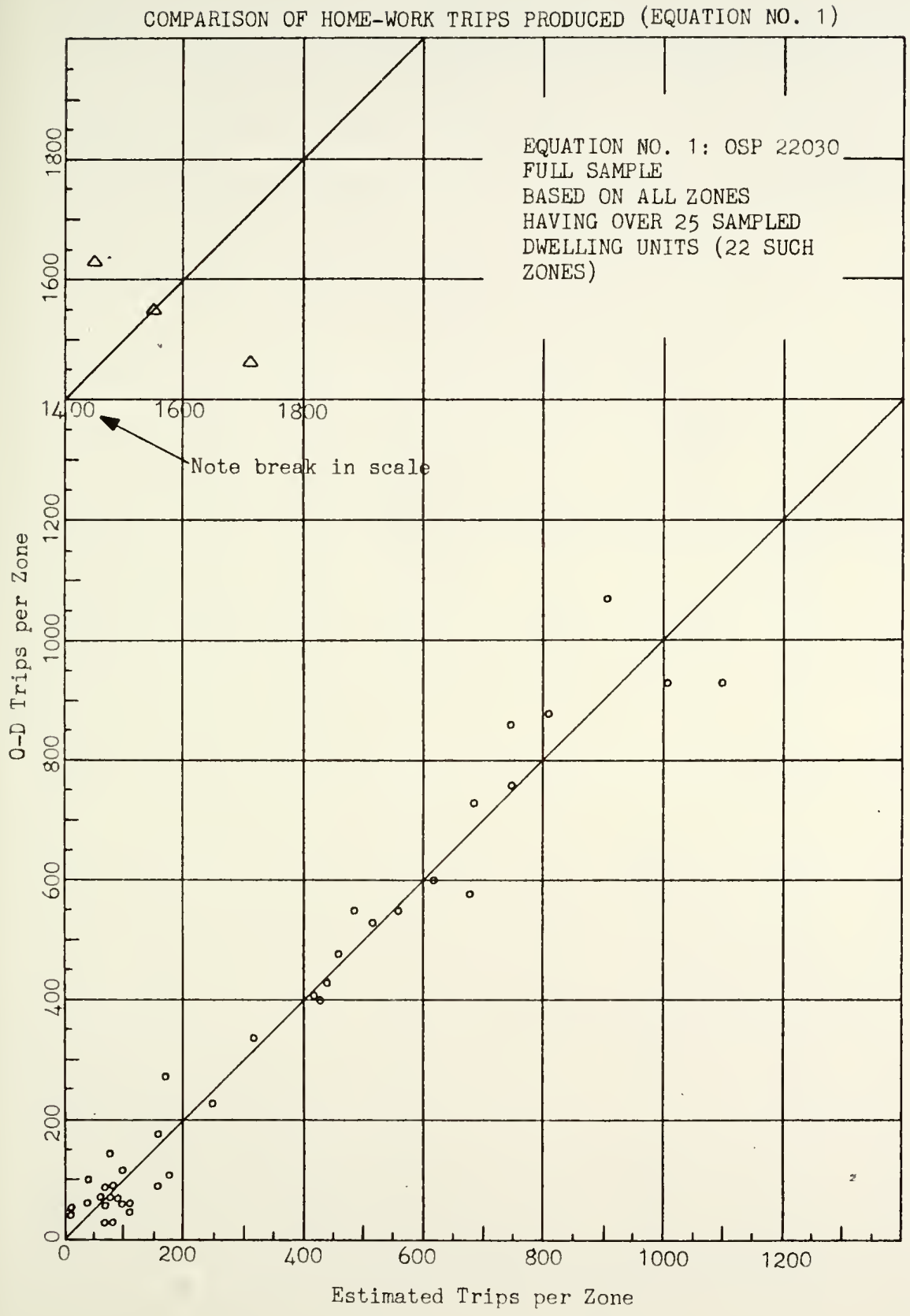


FIGURE 15

COMPARISON OF HOME-WORK TRIPS PRODUCED (EQUATION NO. 2)

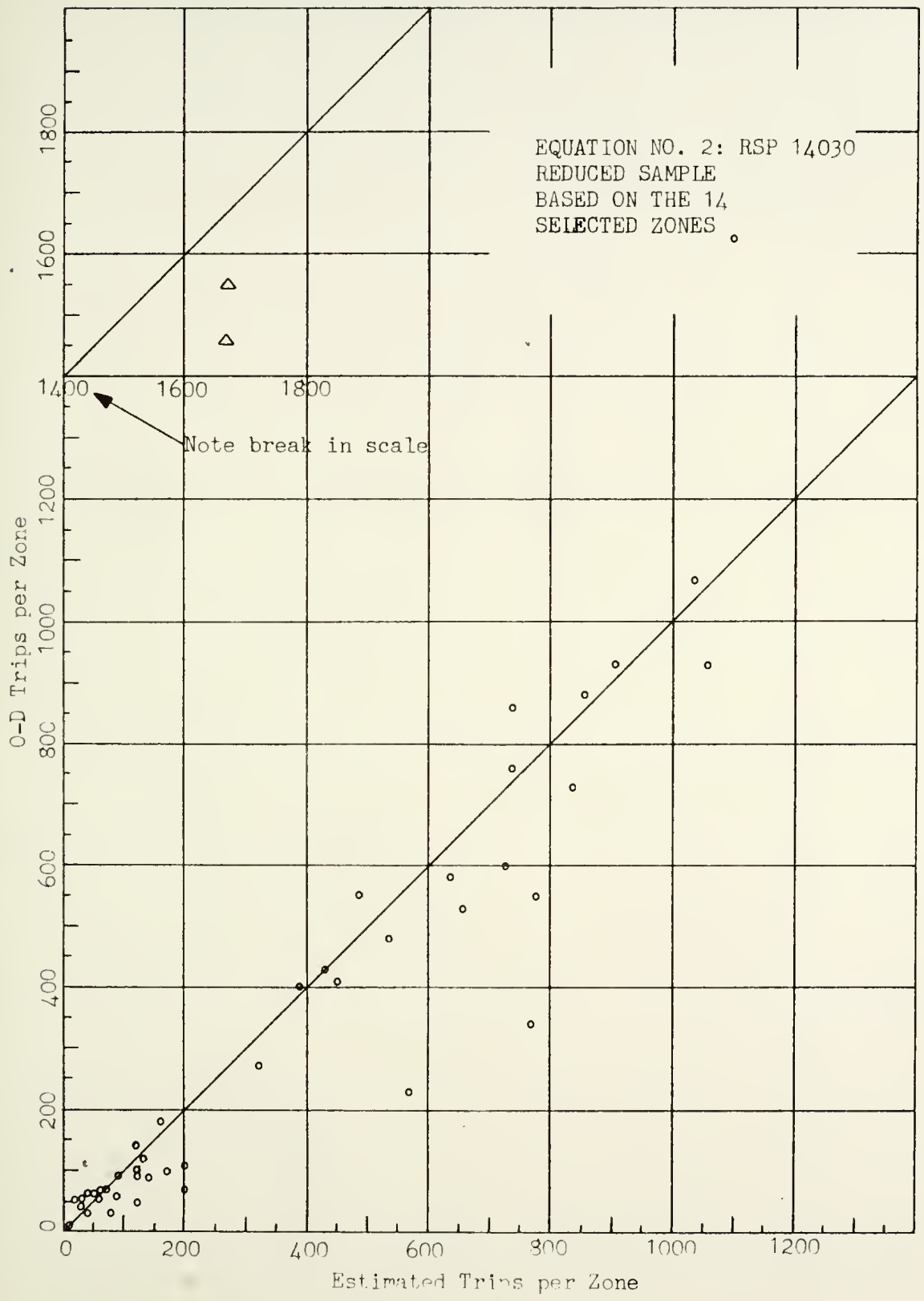




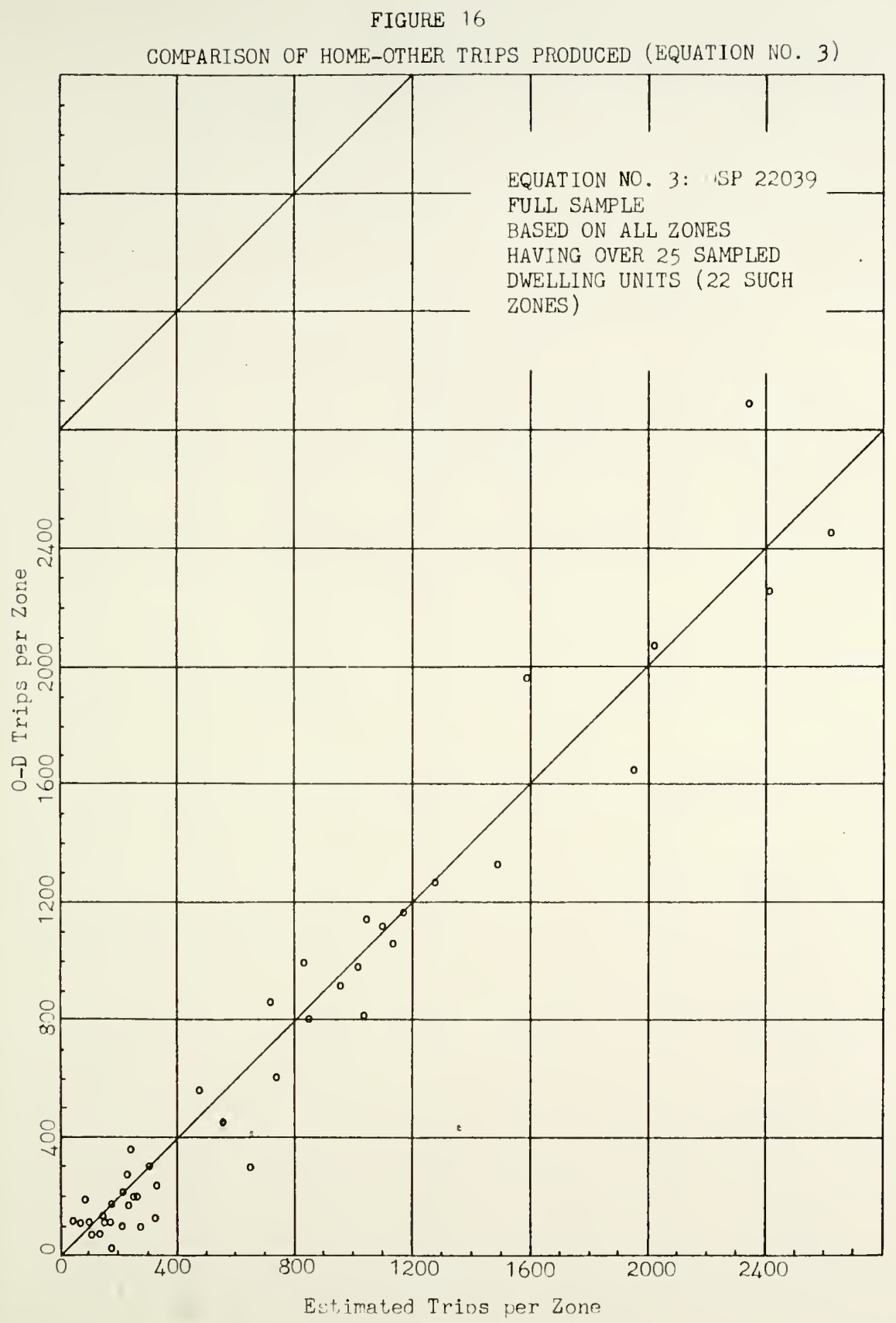




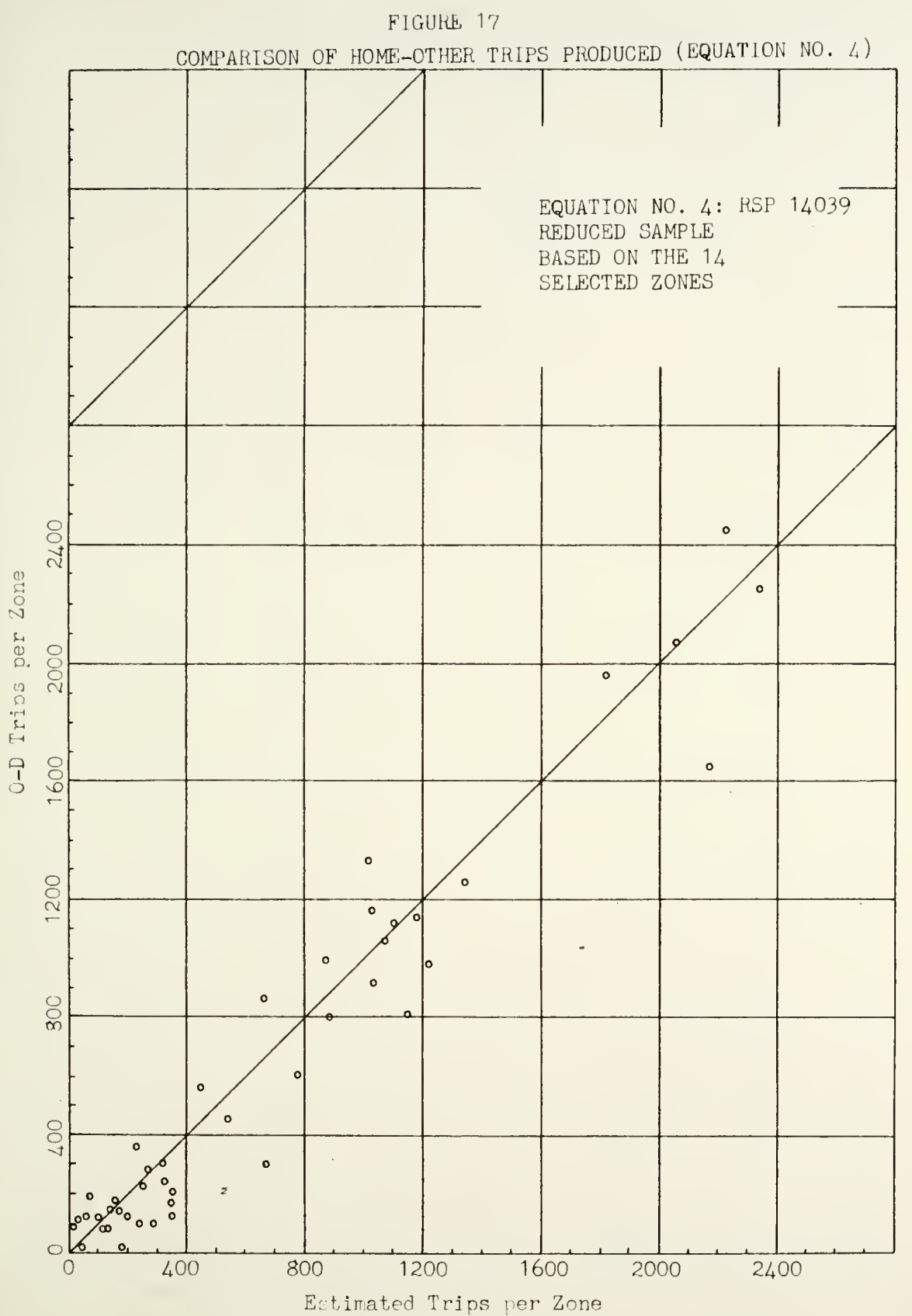


FIGURE 18

COMPARISON OF NON-HOME TRIPS PRODUCED (EQUATION NO. 5)

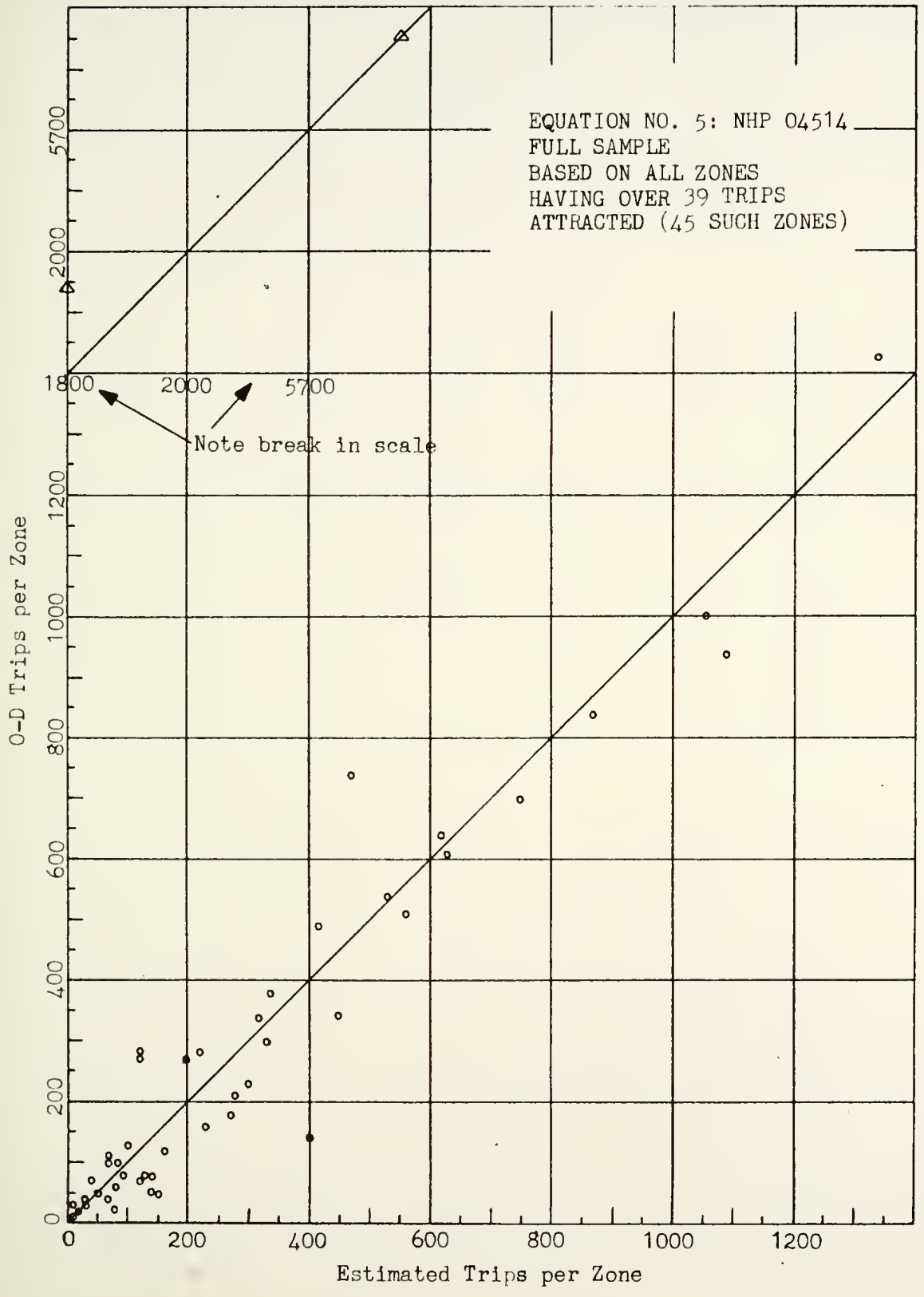




\section{FIGURE 19}

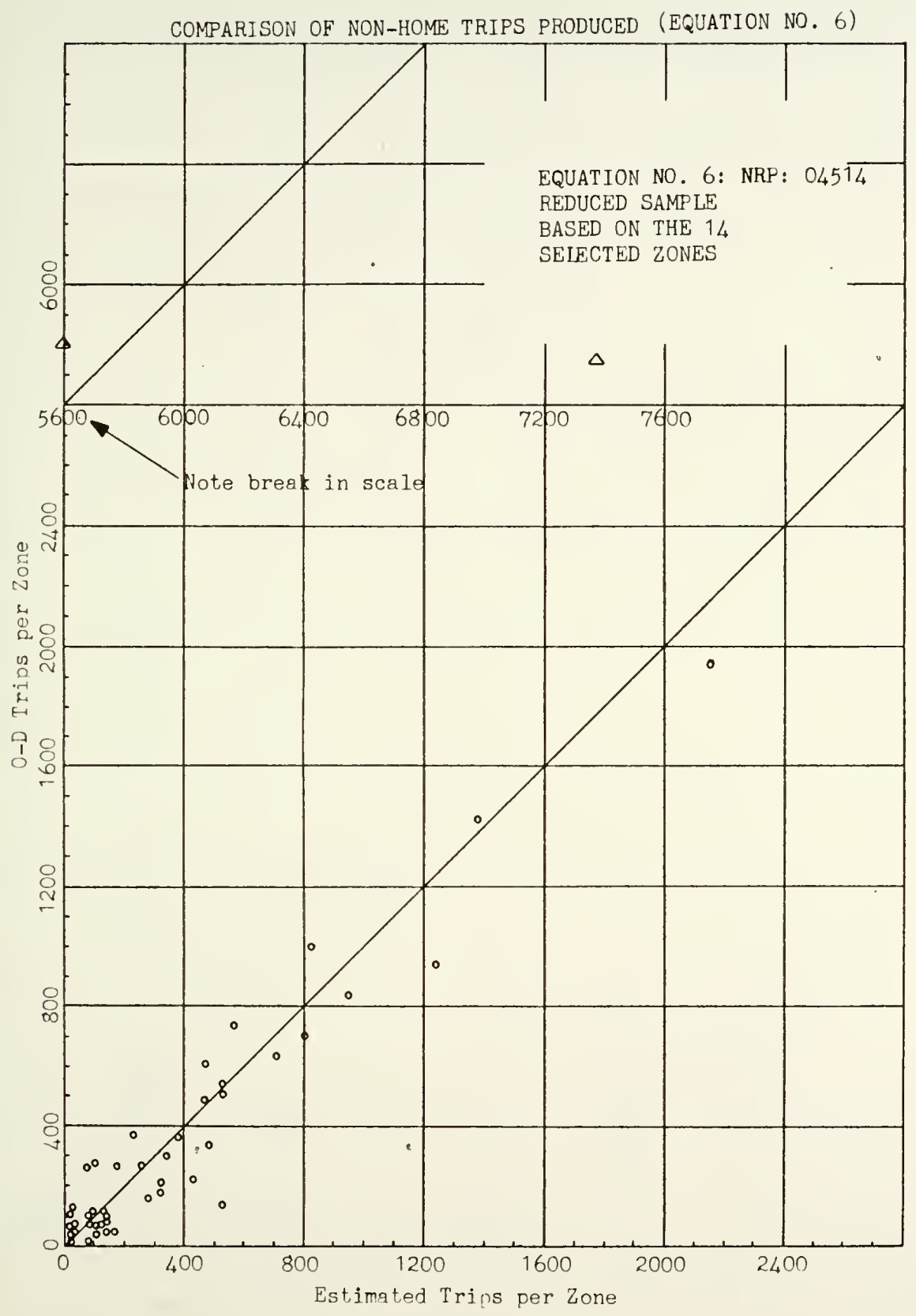


FIGURE 20

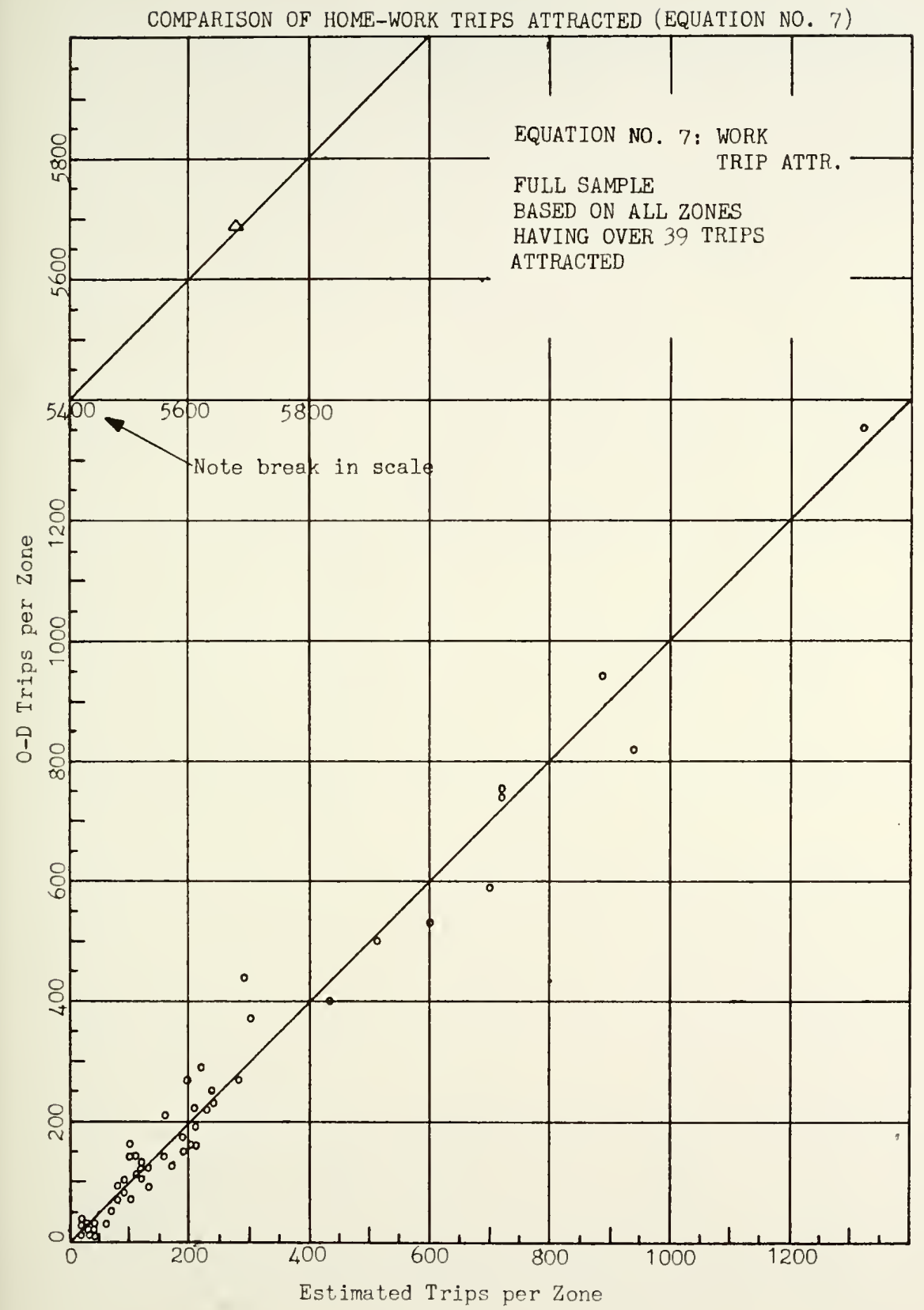


FIGURE 21

COMPARISON OF HOME-WORK TRIPS ATTRACTED (EQUATION NO. 8)

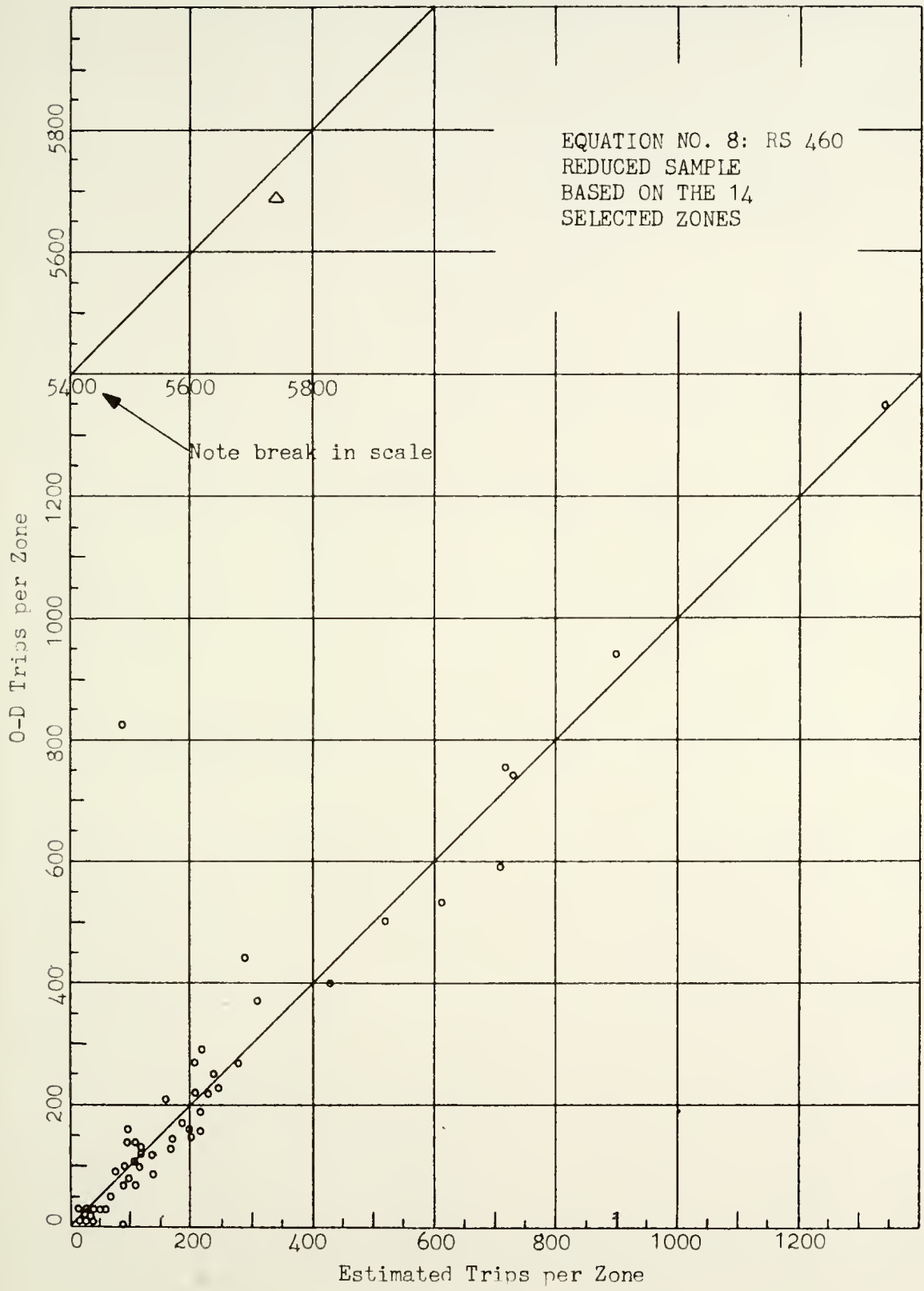


FIGURE 22

COMPARISON OF HOME-OTHER TRIPS ATTRACTED (EQUATION NO. 9)

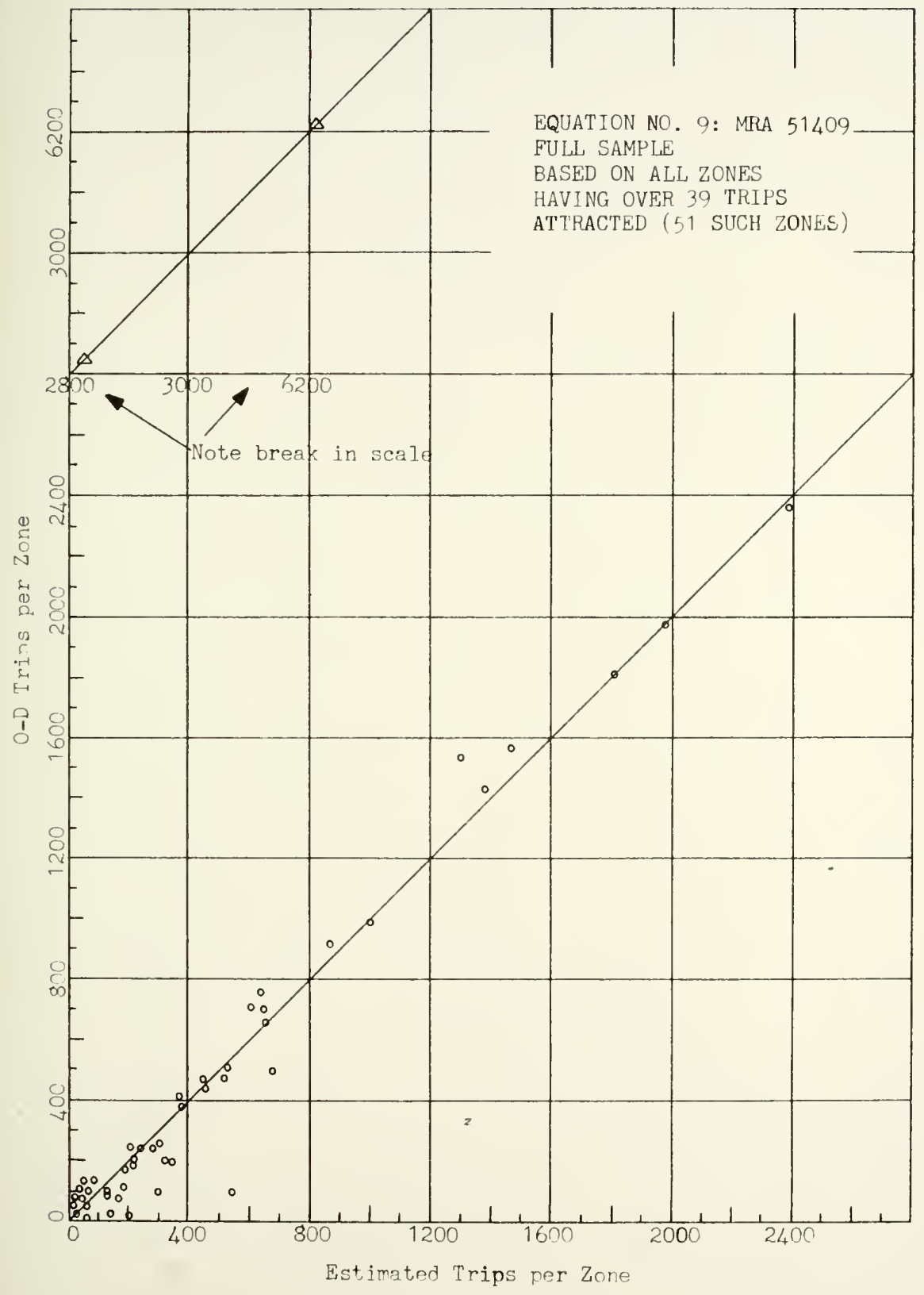


FIGURE 23

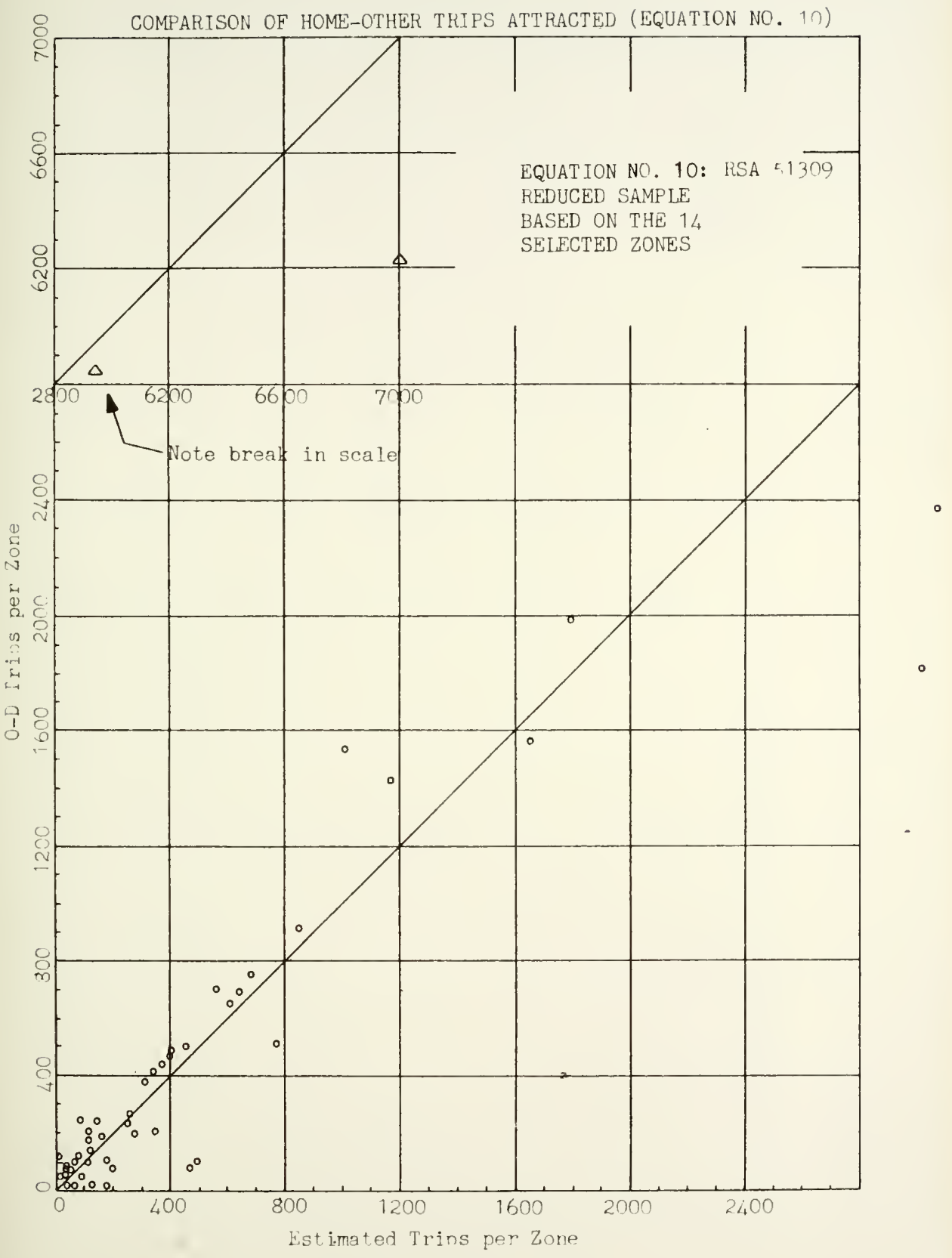




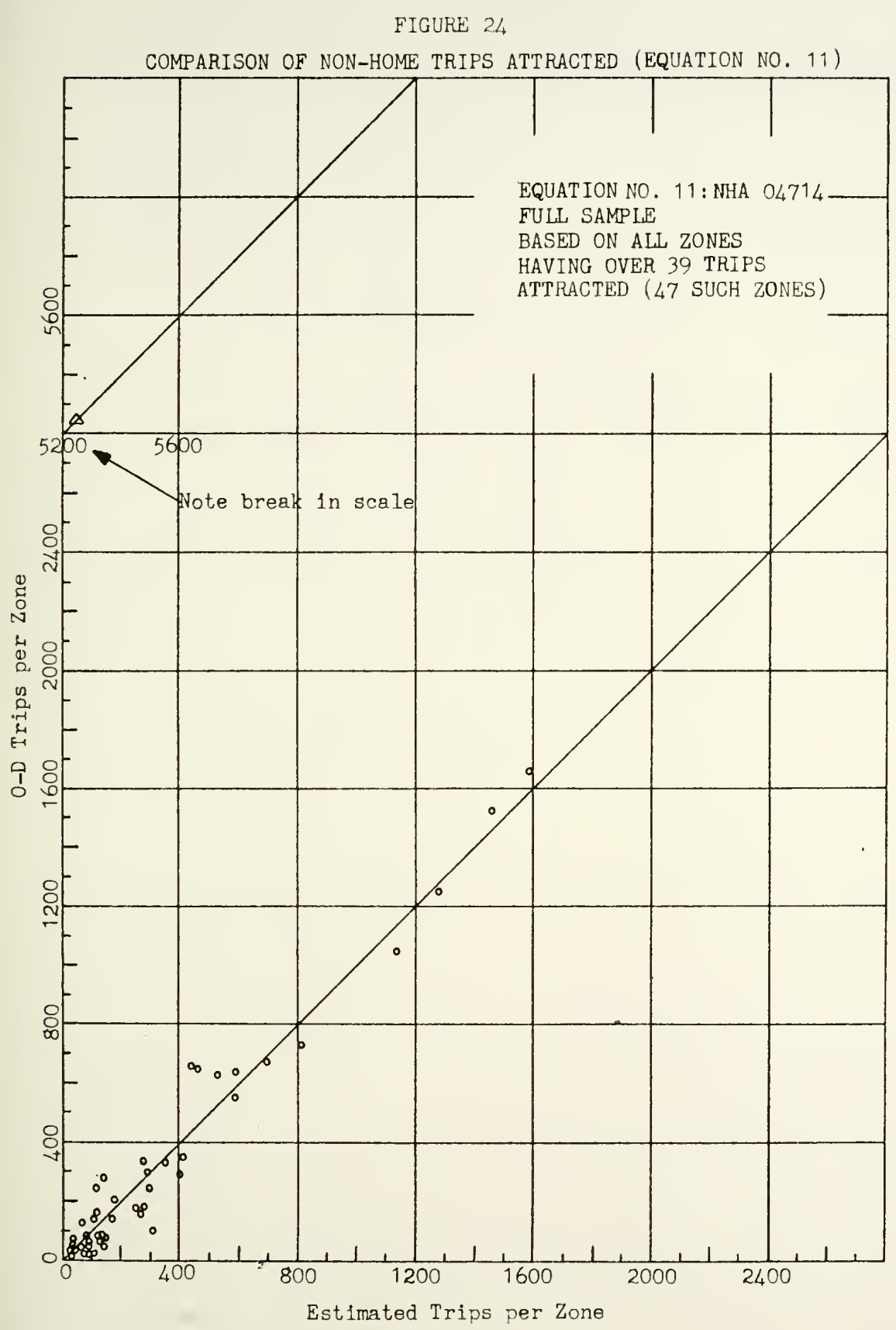


FIGURE 25

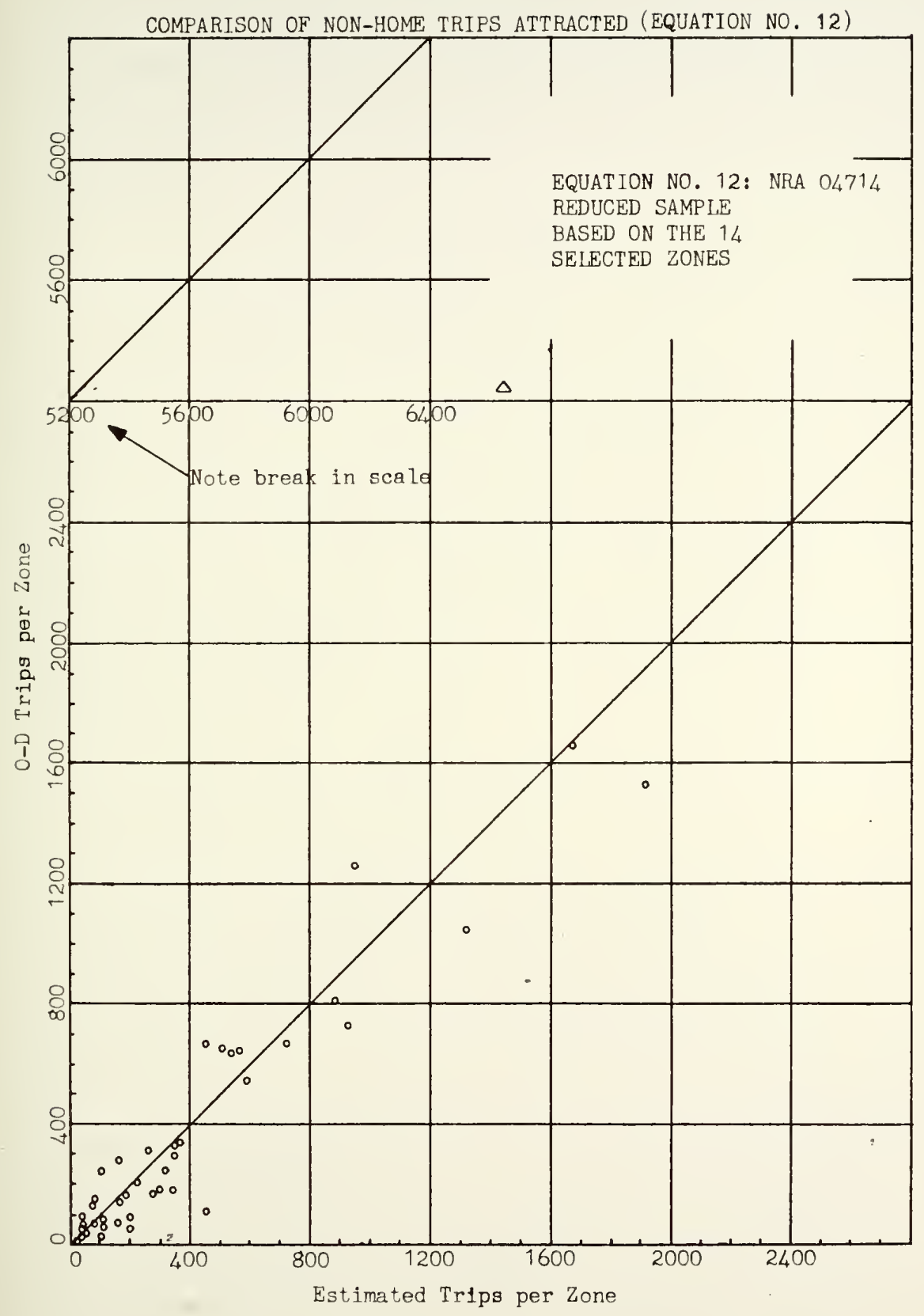


Tables 19 through 25 show both the estimated and the O-D values of trip production and attraction by zone and district. The districts were zone groupings used in the analysis of the distribution of trips by the model.

\section{Gravity Model Distribution}

As noted, two sets of travel time factors were developed. One set, $F_{1}$, was based upon the $O-D$ productions, attractions and trip length frequency distribution as obtained from the comprehensive O-D data in all zones and the other, $F_{2}$, was based upon productions, attractions and the trip length frequency distribution obtained from the reduced sample in the 14 selected zones. Table 14 shows the developed travel time factors. The trip distribution of the model was analyzed using the following four combinations of model parameters:

Combination 1: O-D productions, attractions, and travel time factors, $F_{1}$.

Combination 2: O-D productions, attractions, and travel time factors, $\mathrm{F}_{2}$.

Combination 3: Estimated productions, attractions, and travel time factors, $F_{1}$.

Combination 4: Estimated productions, attractions, and travel time factors, $F_{2}$.

\section{Screenline Comparison}

Seven "screenlines" were chosen for a comparison of screenline crossings using the $O-D$ data and the crossings obtained from the gravity model with the various combinations of parameters.2 The location of the various screenlines is shown in Figure 1. 
TABLE 19

COMPARISON OF HOME-WORK TRIP PRODUCTION AND ATTRACTION

VALUES FROM O-D AND EST IMATING EQUATIONS

FULL SAMPLE

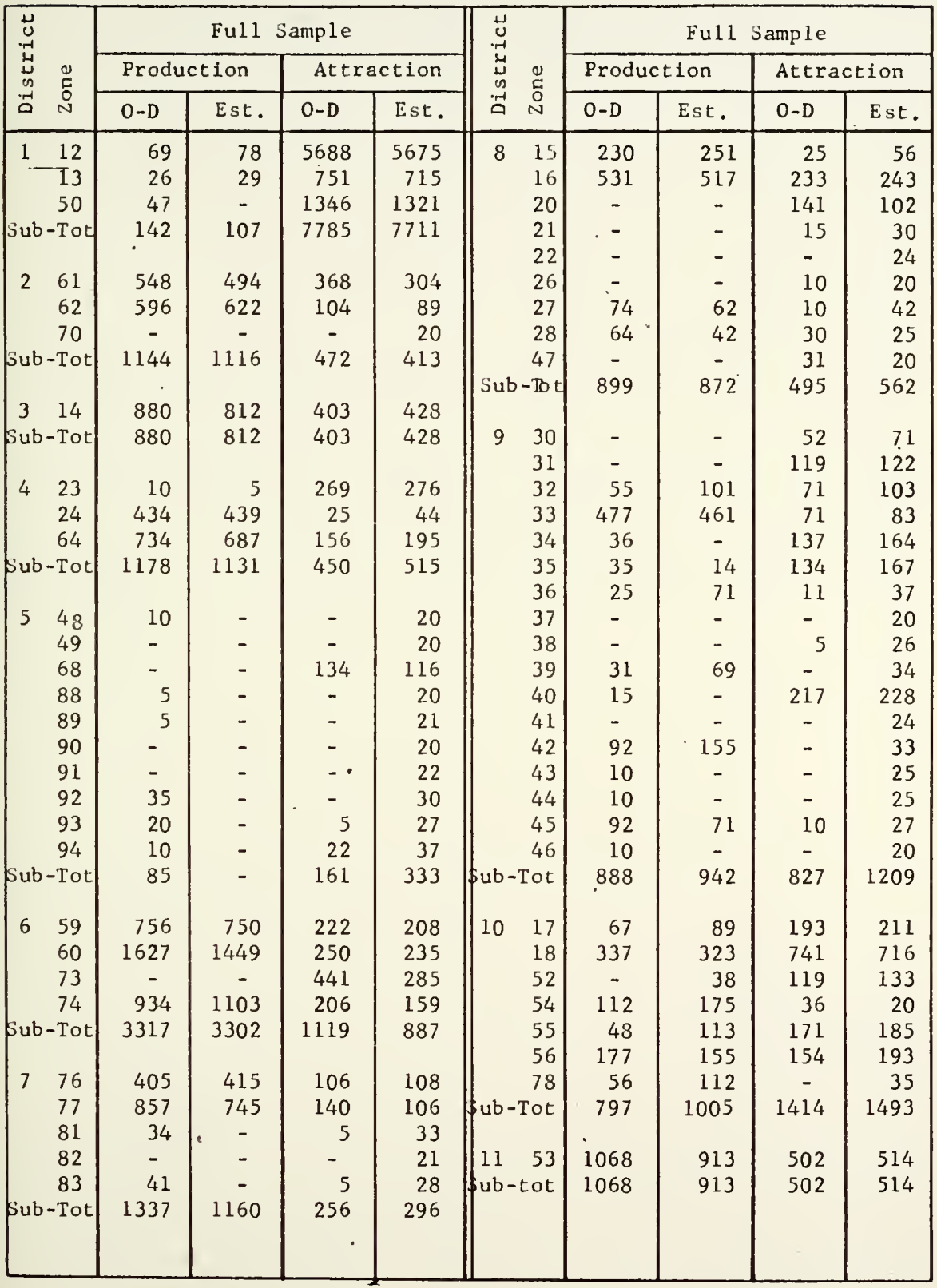


TABLE 19 (Cont.)

\begin{tabular}{|c|c|c|c|c|c|c|c|c|c|c|c|}
\hline \multirow{3}{*}{$\begin{array}{l}\vec{u} \\
-\vec{u} \\
\Delta \\
0 \\
-\overrightarrow{0}\end{array}$} & \multirow{3}{*}{ 嵌 } & \multicolumn{4}{|c|}{ Full Sample } & \multirow{3}{*}{ 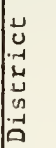 } & \multirow{3}{*}{ 号 } & \multicolumn{4}{|c|}{ Full Sample } \\
\hline & & \multicolumn{2}{|c|}{ Production } & \multicolumn{2}{|c|}{ Attraction } & & & \multicolumn{2}{|c|}{ Production } & \multicolumn{2}{|c|}{ Attraction } \\
\hline & & $O-D$ & Est. & $O-D$ & Est. & & & $O-D$ & Est. & $O-D$ & Est. \\
\hline \multirow[t]{6}{*}{12} & & 273 & 165 & 31 & 39 & 15 & 29 & - & - & 11 & 25 \\
\hline & 72 & 86 & 78 & 155 & 98 & & 65 & 116 & 101 & 592 & 703 \\
\hline & 84 & 102 & - & 5 & 28 & & 66 & - & - & 816 & 935 \\
\hline & 85 & 51 & 13 & 96 & 115 & & 67 & 139 & 80 & 88 & 77 \\
\hline & 86 & - & - & 21 & 42 & & 69 & - & - & - & 90 \\
\hline & 87 & 104 & 38 & 76 & 87 & & -Tot & 255 & 181 & 1669 & 2044 \\
\hline \multirow{2}{*}{\multicolumn{2}{|c|}{ Sub-To }} & 616 & 294 & 384 & 409 & & & & & & \\
\hline & & & & & & 16 & 75 & 931 & 1006 & 272 & 204 \\
\hline \multirow[t]{2}{*}{13} & 19 & 546 & 556 & 286 & 218 & & 79 & 61 & 71 & 11 & 40 \\
\hline & 63 & 1552 & 1556 & 525 & 600 & & 80 & - & - & - & 24 \\
\hline \multicolumn{2}{|c|}{ Sub-Tot } & 2098 & 2112 & 811 & 818 & & -Tot & 992 & 1077 & 283 & 268 \\
\hline 14 & 51 & 1460 & 1709 & 938 & 886 & 17 & 57 & 400 & 429 & 92 & 132 \\
\hline \multirow{3}{*}{\multicolumn{2}{|c|}{$\begin{array}{cr}\text { Sub-Tot } \\
15 & 25\end{array}$}} & 1460 & 1709 & 938 & 886 & & 58 & 578 & 677 & 83 & 94 \\
\hline & & & & & & & -Tot & 978 & 1106 & 175 & 226 \\
\hline & & 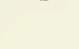 & 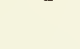 & 102 & 214 & & & 18134 & 17839 & 18144 & 19012 \\
\hline
\end{tabular}


TABLE 20

COMPARISON OF HOME-WORK TRIP PRODUCTION AND ATTRACTION

VALUES FROM O-D AND ESTIMATING EQUATIONS

REDUCED SAMPLE

\begin{tabular}{|c|c|c|c|c|c|c|c|c|c|c|c|}
\hline \multirow{3}{*}{ 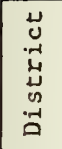 } & \multirow{3}{*}{$\begin{array}{l}\text { むే } \\
\text { Oั } \\
\text { N }\end{array}$} & \multicolumn{4}{|c|}{ Reduced Sample } & \multirow{3}{*}{\multicolumn{2}{|c|}{ 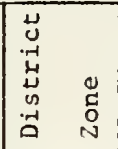 }} & \multicolumn{4}{|c|}{ Reduced Sample } \\
\hline & & \multicolumn{2}{|c|}{ Production } & \multicolumn{2}{|c|}{ Attraction } & & & \multicolumn{2}{|c|}{ Production } & \multicolumn{2}{|c|}{ Attraction } \\
\hline & & $O-D$ & Est. & $O-D$ & Est. & & & $O-D$ & Est. & $0-D$ & Est. \\
\hline \multirow[t]{3}{*}{1} & 12 & 69 & 57 & 5688 & 5739 & 8 & 15 & 230 & 572 & 25 & 58 \\
\hline & I3 & 26 & 76 & 751 & 724 & & 16 & 531 & 659 & 233 & 247 \\
\hline & 50 & 47 & 32 & 1346 & 1337 & & 20 & - & - & 141 & 104 \\
\hline \multirow{2}{*}{\multicolumn{2}{|c|}{ Sub-Tot }} & 142 & 165 & 7785 & 7800 & & 21 & - & - & 15 & 32 \\
\hline & & & & & & & 22 & - & - & - & 25 \\
\hline \multirow[t]{3}{*}{2} & 61 & 548 & 485 & 368 & 309 & & 26 & - & - & 10 & 22 \\
\hline & 62 & 596 & 734 & 104 & 91 & & 27 & 74 & 69 & 10 & 43 \\
\hline & 70 & - & - & - & 22 & & 28 & 64 & 56 & 30 & 26 \\
\hline \multirow{2}{*}{\multicolumn{2}{|c|}{ Sub-Tot }} & 1144 & 1219 & 472 & 422 & & 47 & - & - & 31 & 22 \\
\hline & & & & & & jub-T & ot & 899 & 1356 & 495 & 579 \\
\hline 3 & 14 & 880 & 855 & 403 & 434 & & & & & & \\
\hline \multirow[t]{2}{*}{ Sub. } & - Tot & 880 & 855 & 403 & 434 & 9 & 30 & - & - & 52 & 73 \\
\hline & & & & & & & 31 & - & - & 119 & 124 \\
\hline \multirow[t]{3}{*}{4} & 23 & 10 & 10 & 269 & 280 & & 32 & 55 & 86 & 71 & 105 \\
\hline & 24 & 434 & 426 & 25 & 46 & & 33 & 477 & 536 & 71 & 86 \\
\hline & 64 & 734 & 838 & 156 & 199 & & 34 & 36 & - & 137 & 167 \\
\hline \multirow{2}{*}{\multicolumn{2}{|c|}{ Sub-Tot }} & 1178 & 1274 & 450 & 525 & & 35 & 35 & 28 & 134 & 170 \\
\hline & & & & & & & 36 & 25 & 36 & 11 & 39 \\
\hline \multirow[t]{10}{*}{5} & 48 & 10 & - & - & 20 & & 37 & - & - & - & 22 \\
\hline & 49 & - & - & - & 22 & & 38 & - & 65 & 5 & 27 \\
\hline & 68 & - & - & 134 & 119 & & 39 & 31 & - & - & 35 \\
\hline & 88 & 5 & - & - & 22 & & 40 & 15 & - & 217 & 232 \\
\hline & 89 & 5 & - & - & 23 & & 41 & - & - & - & 25 \\
\hline & 90 & - & - & - & 22 & & 42 & 92 & $\cdot 121$ & - & 34 \\
\hline & 91 & - & - & - & 24 & & 43 & 10 & - & - & 26 \\
\hline & 92 & 35 & - & - & 32 & & 44 & 10 & - & - & 26 \\
\hline & 93 & 20 & - & 5 & 28 & & 45 & 92 & 90 & 10 & 28 \\
\hline & 94 & 10 & - & 22 & 39 & & 46 & 10 & - & - & 22 \\
\hline \multicolumn{2}{|c|}{ Sub-Tot } & 85 & - & 161 & 351 & jub-T & ot & 888 & 962 & 827 & 1241 \\
\hline \multirow[t]{4}{*}{6} & 59 & 756 & 743 & 222 & 211 & 10 & 17 & 67 & 205 & 193 & 215 \\
\hline & 60 & 1627 & 1098 & 250 & 239 & & 18 & 337 & 765 & 741 & 725 \\
\hline & 73 & - & - & 441 & 289 & & 52 & - & 62 & 119 & 136 \\
\hline & 74 & 934 & 909 & 206 & 162 & & 54 & 112 & 204 & 36 & 22 \\
\hline \multirow{2}{*}{\multicolumn{2}{|c|}{ Sub-Tot }} & 3317 & 2750 & 1119 & 901 & & 55 & 48 & 22 & $17 i$ & 188 \\
\hline & & & & & & & 56 & 177 & 159 & 154 & 196 \\
\hline \multirow[b]{6}{*}{ Sub } & 76 & 405 & 447 & 106 & 111 & & 78 & 56 & 56 & - & 36 \\
\hline & 77 & 857 & 742 & 140 & 108 & pub-T & ot & 797 & 1473 & 1414 & 1518 \\
\hline & 81 & 34 & - & 5 & 34 & & & & & & \\
\hline & 82 & - & - & - & 23 & 11 & 53 & 1068 & 1040 & 502 & 521 \\
\hline & 83 & 41 & - & 5 & 30 & Sub-T & ot & 1068 & 1040 & $=502$ & 521 \\
\hline & - Tot & 1337 & 1189 & 256 & 306 & & & & & & \\
\hline
\end{tabular}


TABLE 20 (Cont.)

\begin{tabular}{|c|c|c|c|c|c|c|c|c|c|c|c|}
\hline \multirow{3}{*}{\multicolumn{2}{|c|}{ 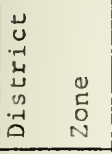 }} & \multicolumn{4}{|c|}{ Reduced sample } & \multirow{3}{*}{ 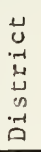 } & \multirow{3}{*}{$\begin{array}{c}0 \\
0 \\
0 \\
0 \\
ن\end{array}$} & \multicolumn{4}{|c|}{ Reduced Sample } \\
\hline & & \multicolumn{2}{|c|}{ Production } & \multicolumn{2}{|c|}{ Attraction } & & & \multicolumn{2}{|c|}{ Production } & \multicolumn{2}{|c|}{ Attraction } \\
\hline & & $0-D$ & Est. & O-D & Est. & & & $0-D$ & Est. & $0-D$ & Est. \\
\hline \multirow{6}{*}{$\begin{array}{l}7 \\
7 \\
8 \\
8 \\
8 \\
8\end{array}$} & 71 & 273 & 324 & 31 & 41 & 15 & 29 & - & - & 11 & 26 \\
\hline & 72 & 86 & $1 /$ & 155 & 100 & & 65 & 116 & 132 & 592 & 712 \\
\hline & 84 & 102 & 166 & 5 & 30 & & 66 & - & - & 816 & 94 \\
\hline & 85 & 51 & 119 & 96 & 118 & & 67 & 139 & 124 & 88 & 79 \\
\hline & 86 & - & - & 21 & 43 & & 69 & - & - & - & 92 \\
\hline & 87 & 104 & 118 & 76 & 89 & & - Tot & 255 & 256 & 1669 & 1217 \\
\hline \multirow{2}{*}{\multicolumn{2}{|c|}{ Sub-Tot }} & 616 & 868 & 384 & 421 & & & & & & \\
\hline & & & & & & 1.6 & 75 & 931 & 1059 & 272 & 208 \\
\hline \multirow[t]{3}{*}{13} & 19 & 546 & 784 & 286 & 222 & & 79 & 61 & 52 & 11 & 42 \\
\hline & 63 & 1552 & 1556 & 525 & 608 & & 80 & - & - & - & 25 \\
\hline & - Tot & 2098 & 2340 & 811 & 830 & & Tot & 992 & 1111 & 283 & 275 \\
\hline \multirow{3}{*}{$\begin{array}{l}14 \\
\text { Jub }\end{array}$} & 51 & 1460 & 1671 & 933 & 898 & & 57 & 400 & 392 & 92 & 135 \\
\hline & $-\operatorname{Tot}$ & 1460 & 1671 & 938 & 898 & & 58 & 573 & 640 & 83 & 96 \\
\hline & & & & & & & Tot & 978 & 1032 & 175 & 231 \\
\hline 15 & 25 & - & - & 162 & 214 & & al & 18134 & 19561 & 18144 & 13470 \\
\hline
\end{tabular}


TABLE 21

COMPARISON OF HOME-OTHER TRIP PRODUCTION AND ATTRACT ION

VALUES FROM O-D AND EST TMATING EQUATIONS

FULL SAMPLE

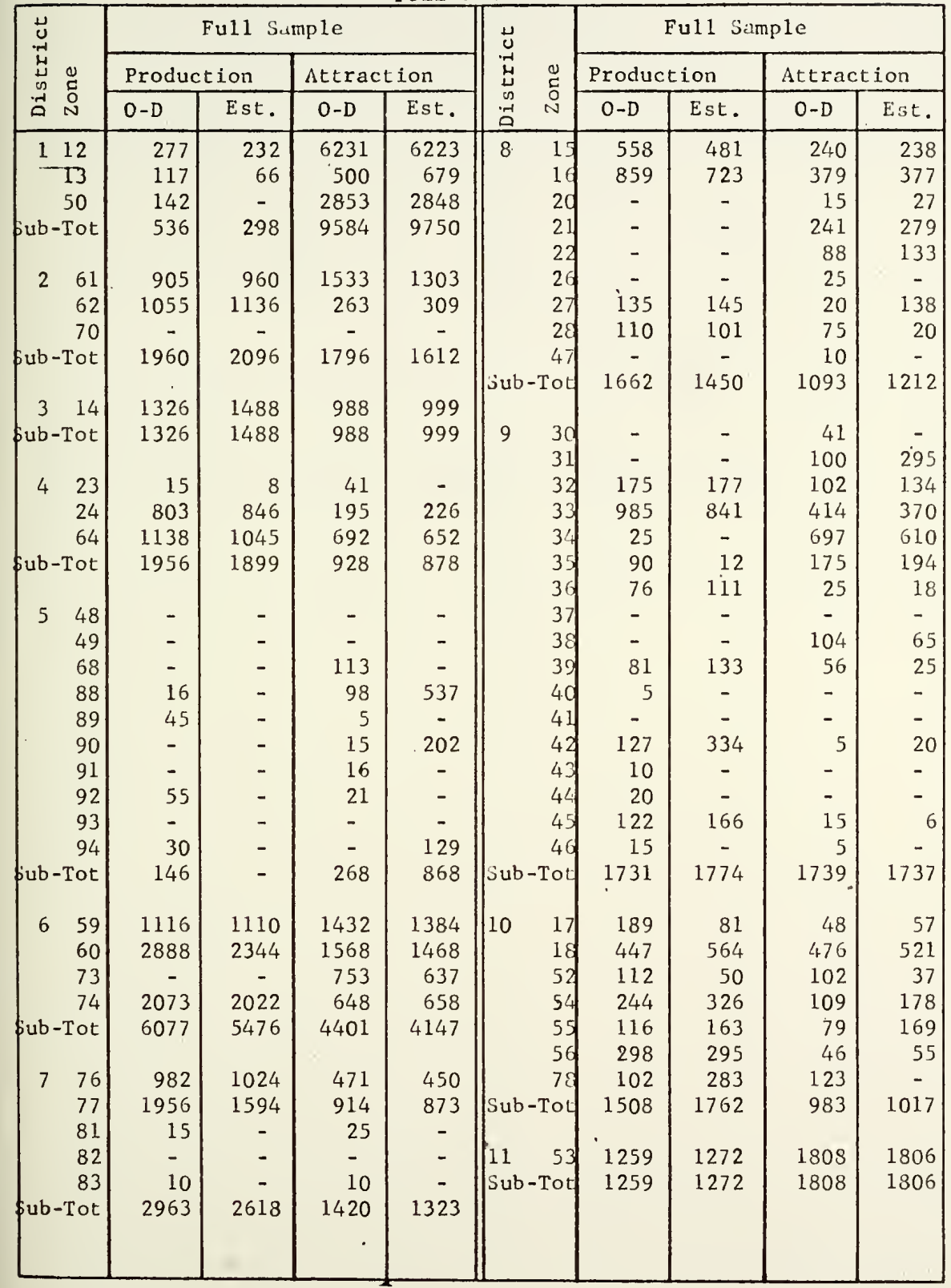


TABLE 21 (Cont.)

\begin{tabular}{|c|c|c|c|c|c|c|c|c|c|}
\hline \multirow{3}{*}{ 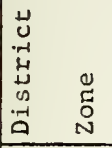 } & \multicolumn{4}{|c|}{ Full Sumple } & \multirow{3}{*}{ 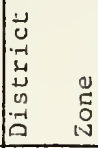 } & \multicolumn{4}{|c|}{ Full Sample } \\
\hline & \multicolumn{2}{|c|}{ Production } & \multicolumn{2}{|c|}{ Attraction } & & \multicolumn{2}{|c|}{ Production } & \multicolumn{2}{|c|}{ Attraction } \\
\hline & $O-D$ & Est. & $0-D$ & Est. & & $O-D$ & Est. & $0-D$ & Est. \\
\hline 1271 & 300 & 645 & 140 & 92 & 152 & - & - & - & - \\
\hline $7_{2}$ & 364 & 235 & 187 & 207 & 6 & 223 & 217 & 254 & 208 \\
\hline 84 & 200 & 247 & 73 & 48 & 6 & - & - & 16 & - \\
\hline 85 & 204 & 256 & 72 & 9 & 6 & 95 & 224 & 16 & 14 \\
\hline 86 & - & - & 16 & 64 & 6 & - & - & - & - \\
\hline 87 & 174 & 242 & 127 & 53 & Bub-To & 318 & 441 & 291 & 222 \\
\hline \multirow{2}{*}{ Sub-Tot } & 1242 & 1625 & 615 & 473 & & & & & \\
\hline & & & & & 167 & 1648 & 1946 & 514 & 530 \\
\hline \multirow[b]{3}{*}{ Sub -? } & 1164 & 1179 & 444 & 461 & 7 & 20 & 178 & 10 & - \\
\hline & 2252 & 2406 & 1976 & 1976 & 8 & - & - & - & - \\
\hline & 3416 & 3585 & 2420 & 2437 & jub-To & 1668 & 2124 & 524 & 530 \\
\hline \multirow{2}{*}{$\begin{array}{l}14 \\
\text { sub }\end{array}$} & 2451 & 2622 & 2374 & 2393 & 175 & 597 & 736 & 197 & $3 \dot{5} 4$ \\
\hline & 2451 & 2622 & 2374 & 2393 & & 811 & 1038 & 204 & 328 \\
\hline & & & & & jub-To & 1408 & 1774 & 401 & 682 \\
\hline & 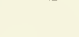 & 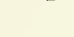 & 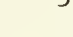 & 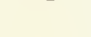 & & & & & \\
\hline & & & & & Total & 31627 & 32304 & 31633 & 32086 \\
\hline
\end{tabular}


COMPARISON OF HOME-OTHER TRIP PRODUCTION AND ATTRACTION

VALUES FROM O-D AND EST IMA'I ING EQUAT IONS

REDUCED SAMPLE

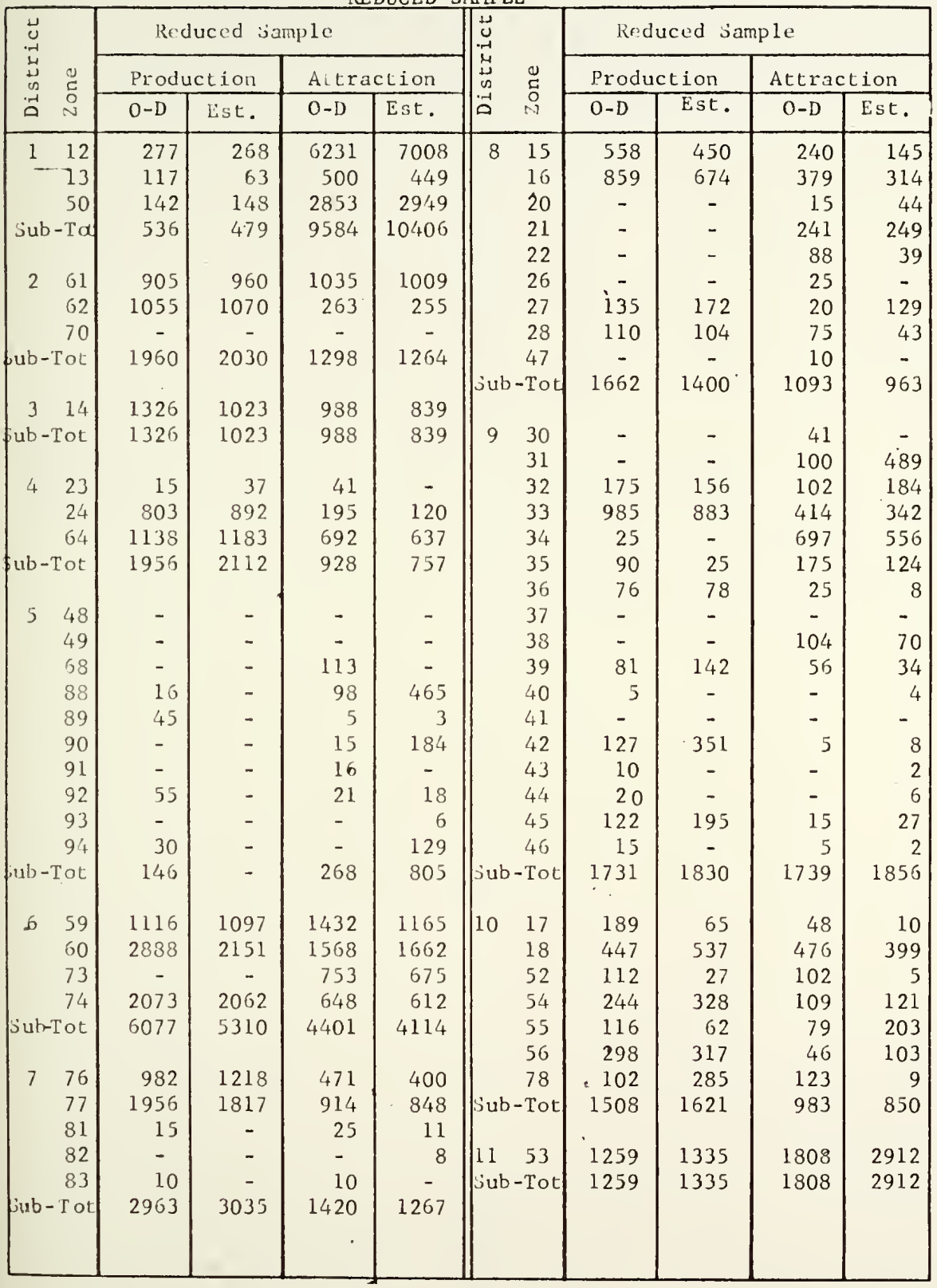


TABLE 22 (Cont.)

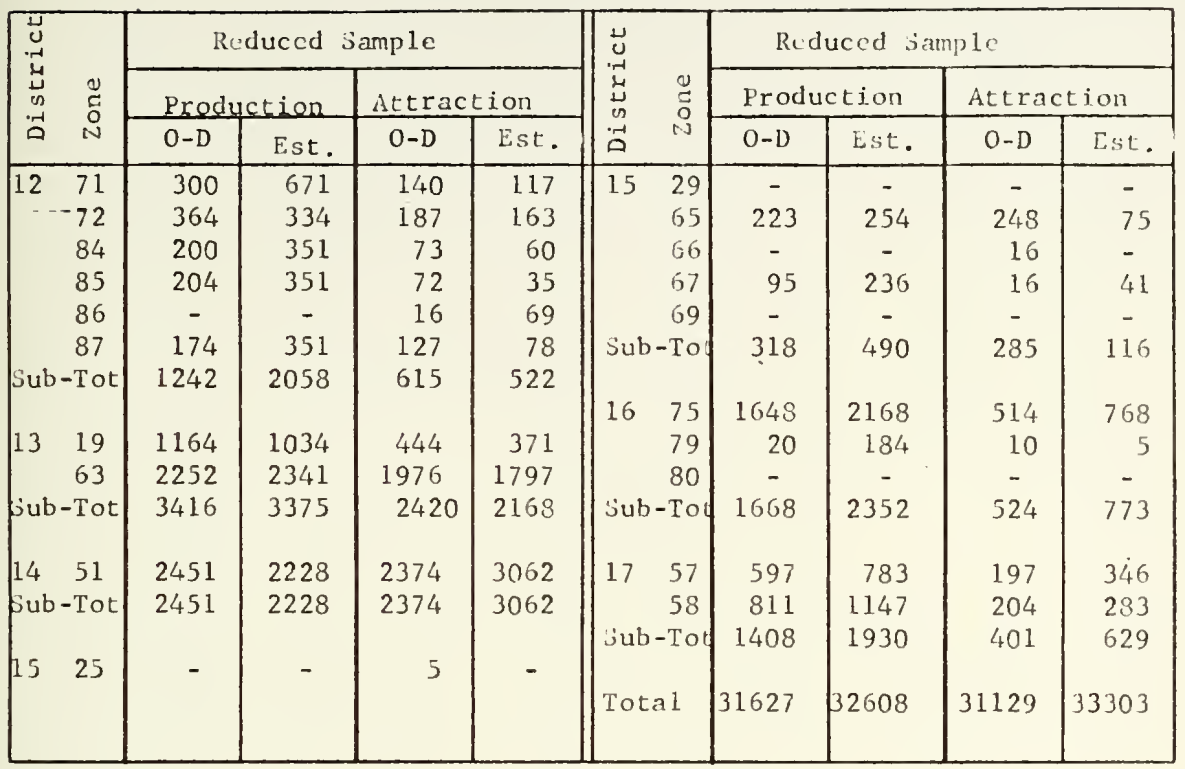


TABLF: 23

COMPARISON OF NON-HOME TRIP PRODUCTION AND ATTRACTION

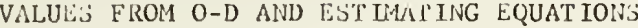

FULL SAMPLE.

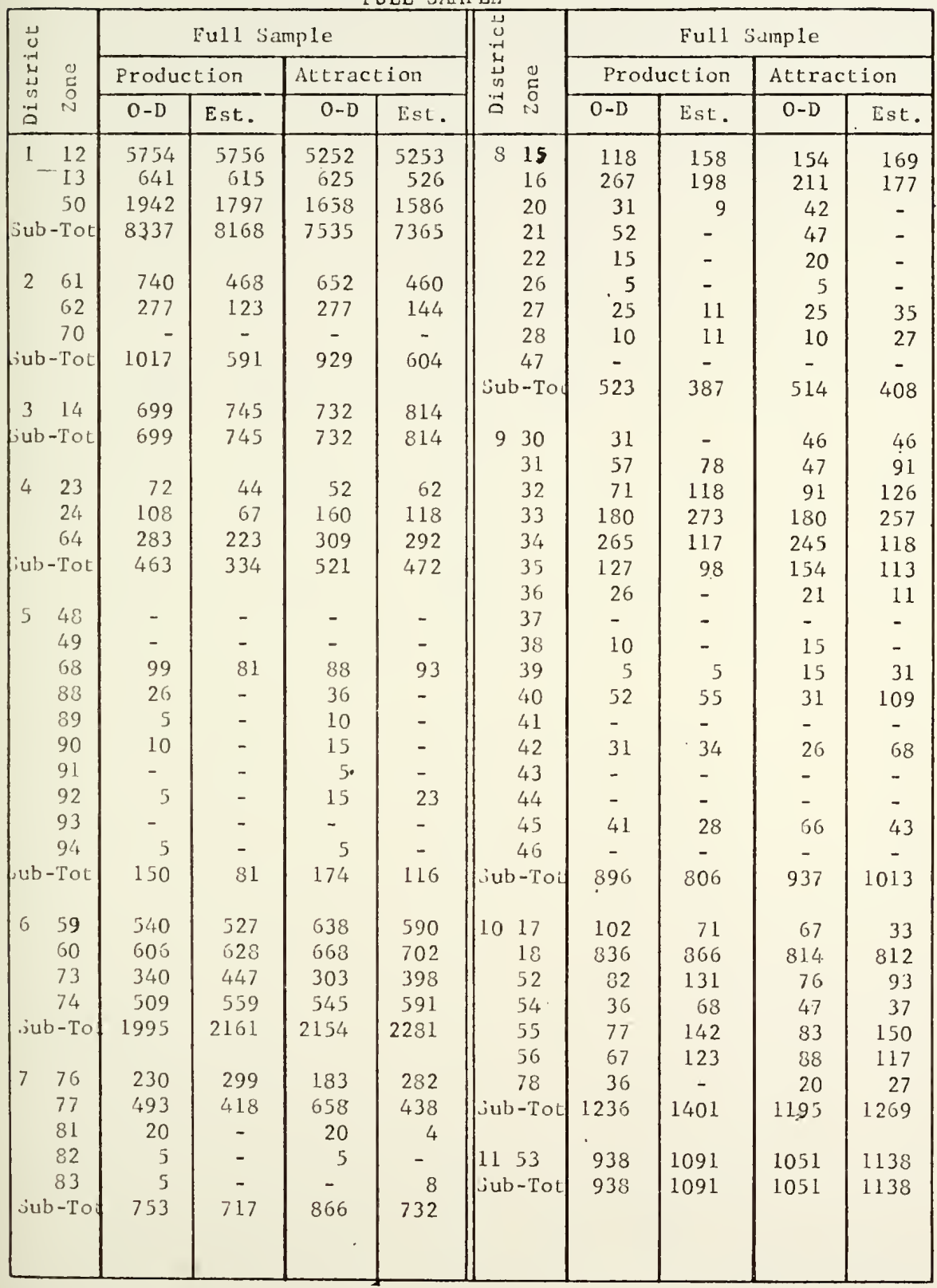


TABLE 23 (Cont.)

\begin{tabular}{|c|c|c|c|c|c|c|c|c|c|c|}
\hline \multirow{3}{*}{\multicolumn{2}{|c|}{ 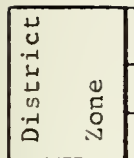 }} & \multicolumn{4}{|c|}{ Full Sample } & \multirow{3}{*}{ 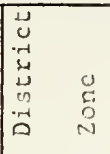 } & \multicolumn{4}{|c|}{ Full sample } \\
\hline & & \multicolumn{2}{|c|}{ Production } & \multicolumn{2}{|c|}{ Attraction } & & \multicolumn{2}{|c|}{ Production } & \multicolumn{2}{|c|}{ AtLraction } \\
\hline & & $O-D$ & Est. & $0-D$ & Est. & & $0-D$ & Est. & $O-D$ & Est. \\
\hline \multirow[t]{8}{*}{$\overline{12}$} & 71 & 47 & 149 & .47 & 140 & 152 & 5 & - & 5 & - \\
\hline & & 103 & 88 & 134 & 67 & 6 & 366 & 324 & 341 & 281 \\
\hline & 84 & 20 & 37 & 36 & 4 & 6 & 140 & 399 & 107 & 313 \\
\hline & 85 & 52 & 138 & 67 & 125 & б́ & 76 & 93 & 61 & 92 \\
\hline & 86 & 5 & - & 11 & 3 & 5 & - & - & $\therefore$ & - \\
\hline & 87 & 20 & 83 & 25 & 92 & jub-To & 639 & 816 & 556 & 686 \\
\hline & - Tot & 247 & 495 & 320 & 431 & & & & & \\
\hline & & & & & & 167 & 374 & 339 & 363 & 414 \\
\hline \multirow[t]{2}{*}{13} & 19 & 304 & 326 & 342 & 349 & 7 & 31 & - & 26 & 23 \\
\hline & 63 & 999 & 1062 & 1251 & 1283 & 8 & - & - & - & - \\
\hline \multicolumn{2}{|c|}{ Sub-Tot } & 1303 & 1388 & 1593 & 1632 & ub-To & 405 & 339 & 389 & 437 \\
\hline \multirow{3}{*}{$\begin{array}{l}14 \\
\text { Sub }\end{array}$} & 51 & 1433 & 1340 & 1528 & 1461 & 17 & 162 & 232 & 172 & 265 \\
\hline & -Tot & 1433 & 1340 & 1528 & 1461 & & 214 & 278 & 246 & 296 \\
\hline & & & & & & jub-To & 376 & 510 & 418 & 561 \\
\hline & 25 & 52 & - & 42 & - & & & 21370 & 21412 & 2142 \\
\hline & & & & & & Total & 21410 & 21370 & 21412 & 21420 \\
\hline
\end{tabular}


TABLE, 24

COMPARTSON OF NON-IIOME TRIP PRODUCTION AND ATTRACTION

VALULS FBOH O-D AND EJTILATING LQUATIOIS

REDUCED SAMPLE

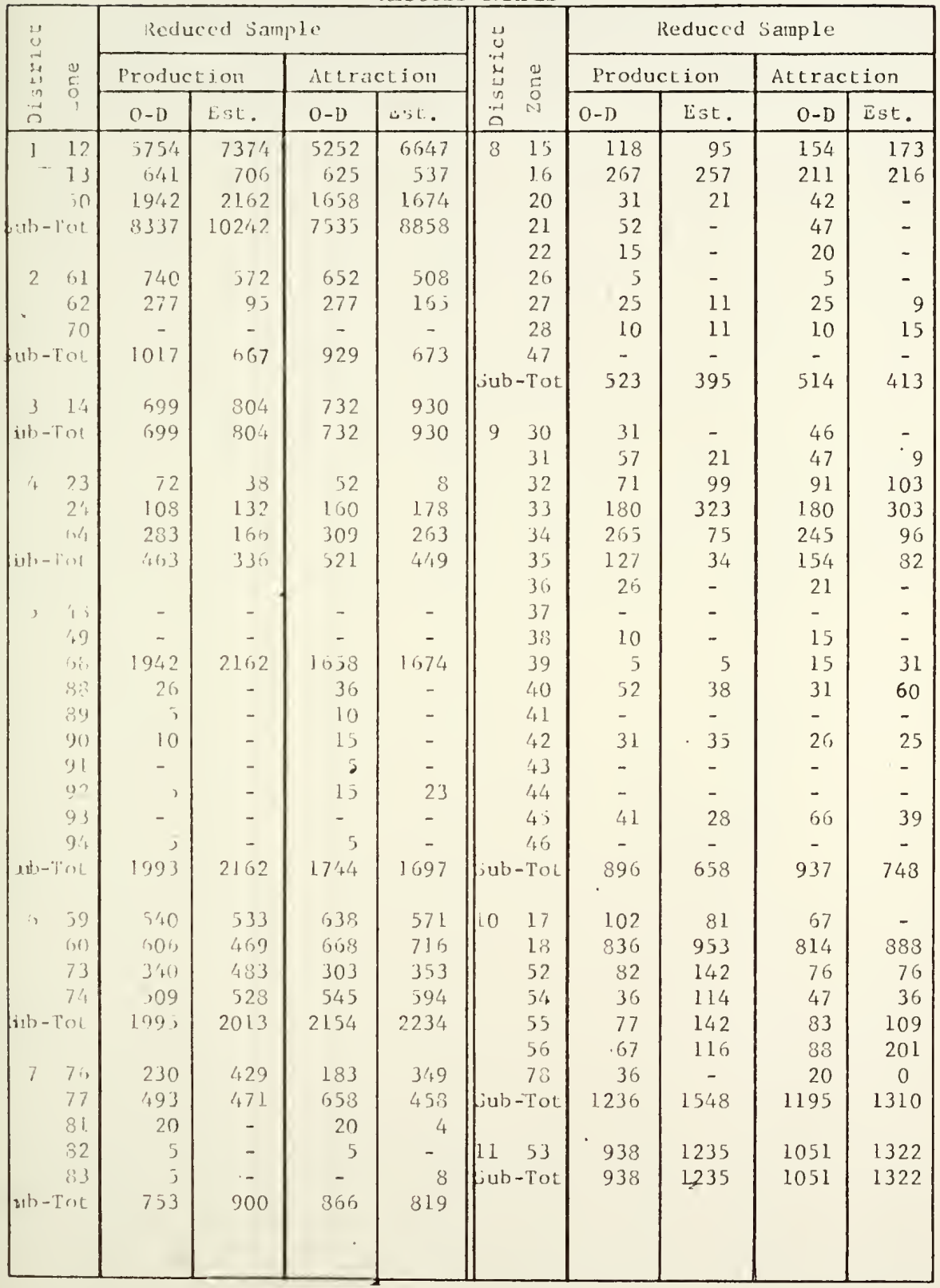


TABLLE 24 (Cont.)

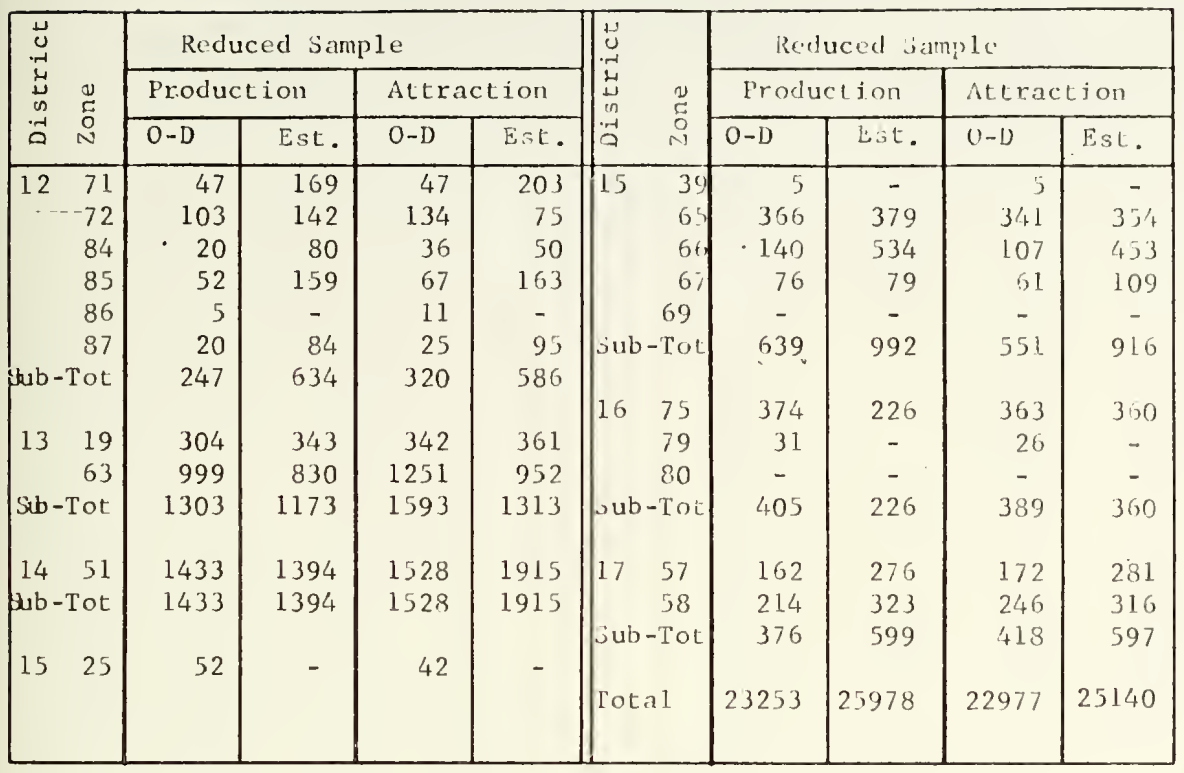


COMPARISON OF NON-HOME TRIP PRODUCTION AND ATTRACT ION VALUES FROM O-D AND EST IMAT ING EQUAT IONS

REDUCED SAMPLE (Ad justed)*

\begin{tabular}{|c|c|c|c|c|c|c|c|c|c|c|c|}
\hline \multirow{3}{*}{$\begin{array}{c} \\
u \\
.1 \\
u \\
u \\
0 \\
.1 \\
0 \\
0\end{array}$} & \multirow{3}{*}{ 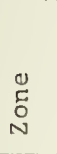 } & \multicolumn{4}{|c|}{ Reduced Sample (Ad justed)* } & \multirow{3}{*}{ 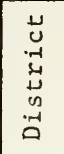 } & \multirow{3}{*}{$\begin{array}{l}\stackrel{0}{\Xi} \\
\stackrel{D}{N} \\
N\end{array}$} & \multicolumn{4}{|c|}{ Reduced Sample (Ad justed)* } \\
\hline & & \multicolumn{2}{|c|}{ Production } & \multicolumn{2}{|c|}{ Attraction } & & & \multicolumn{2}{|c|}{ Production } & \multicolumn{2}{|c|}{ Attraction } \\
\hline & & $0-D$ & list. & O-D & Est. & & & $0-\mathrm{D}$ & Est. & $O-D$ & Est. \\
\hline 1 & 12 & 5754 & 6706 & 5252 & 6045 & 8 & 15 & 118 & 86 & 154 & 157 \\
\hline & I3 & 641 & 642 & $\dot{6} 25$ & 488 & & 16 & 267 & 234 & 211 & 196 \\
\hline & 50 & 1942 & 1966 & 1658 & 1522 & & 20 & 31 & 19 & 42 & - \\
\hline sub & - Tot & 8337 & 9314 & 7535 & 8055 & & 21 & 52 & - & 47 & - \\
\hline & & & & & & & 22 & 15 & - & 20 & - \\
\hline 2 & 61 & 740 & 520 & 652 & 462 & & 26 & 5 & - & 5 & - \\
\hline & 62 & 277 & 86 & 277 & 150 & & 27 & 25 & - & 25 & 8 \\
\hline & 70 & - & - & - & - & & 28 & 10 & - & 10 & 14 \\
\hline jub & - Tot & 1017 & 606 & 929 & 612 & & 47 & -0 & - & - & - \\
\hline & & & & & & Sub & - To & 523 & 339 & 514 & 375 \\
\hline 3 & 14 & 699 & 731 & 732 & 846 & & & & & & \\
\hline Sub & -Tot & 699 & 731 & 732 & 846 & 9 & 30 & 31 & - & 46 & - \\
\hline & & & & & & & 31 & 57 & 19 & 47 & 8 \\
\hline 4 & 23 & 72 & 35 & 52 & 7 & & 32 & 71 & 90 & 91 & 94 \\
\hline & 24 & 108 & 120 & 160 & 162 & & 33 & 180 & 294 & 180 & 276 \\
\hline & 64 & 283 & 151 & 309 & 239 & & 34 & 265 & 68 & 245 & 87 \\
\hline jub & - Tot & 463 & 306 & 521 & 408 & & 35 & 127 & 31 & 154 & 75 \\
\hline & & & & & & & 36 & 26 & - & 21 & - \\
\hline 5 & 48 & - & - & - & - & & 37 & - & - & - & - \\
\hline & 49 & - & - & - & - & & 38 & 10 & - & 15 & - \\
\hline & 68 & 99 & 19 & 88 & 38 & & 39 & 5 & - & 15 & 4 \\
\hline & 88 & 26 & - & 36 & - & & 40 & 52 & 35 & 31 & 55 \\
\hline & 89 & 5 & - & 10 & - & & 41 & - & - & - & - \\
\hline & 90 & 10 & - & 15 & - & & 42 & 31 & 32 & 26 & 23 \\
\hline & 91 & - & - & 5 & - & & 43 & - & - & - & - \\
\hline & 92 & 5 & - & 15 & - & & 44 & - & - & - & - \\
\hline & 93 & - & - & - & - & & 45 & 41 & - & 66 & 35 \\
\hline & 94 & 5 & - & 5 & - & & 46 & - & - & - & - \\
\hline jub & - Tot & 150 & 19 & 174 & 38 & Sub & - To & 896 & 569 & 937 & 657 \\
\hline 6 & 59 & 540 & 485 & 638 & 519 & 10 & 17 & 102 & 74 & 67 & - \\
\hline & 60 & 606 & 427 & 668 & 651 & & 18 & 836 & 867 & 814 & 808 \\
\hline & 73 & 340 & 439 & 303 & 321 & & 52 & 82 & 129 & 76 & 69 \\
\hline & 74 & 509 & 480 & 545 & 540 & & 54 & 36 & 104 & 47 & 33 \\
\hline jub & - Tot & 1995 & 1831 & 2154 & 2031 & & 55 & 77 & 120 & 83 & 99 \\
\hline & & & & & & & 56 & 67 & 105 & 88 & 183 \\
\hline 7 & 76 & 230 & 390 & 183 & 317 & & 78 & 36 & - & 20 & - \\
\hline & 77 & 493 & 428 & 658 & 417 & Sut & -Tou & 1236 & 1399 & 1195 & 1192 \\
\hline & 81 & 20 & - & 20 & - & & & & & & \\
\hline & 82 & ' 5 & - & 5 & - & 11 & 53 & 938 & 1123 & 1051 & 1202 \\
\hline & 83 & 5 & - & - & - & & -Tot & 938 & 1123 & 1051 & 1202 \\
\hline jub & - Tot & 753 & 818 & 866 & 734 & & & & & & \\
\hline
\end{tabular}


TABLE 25 (Cont.)

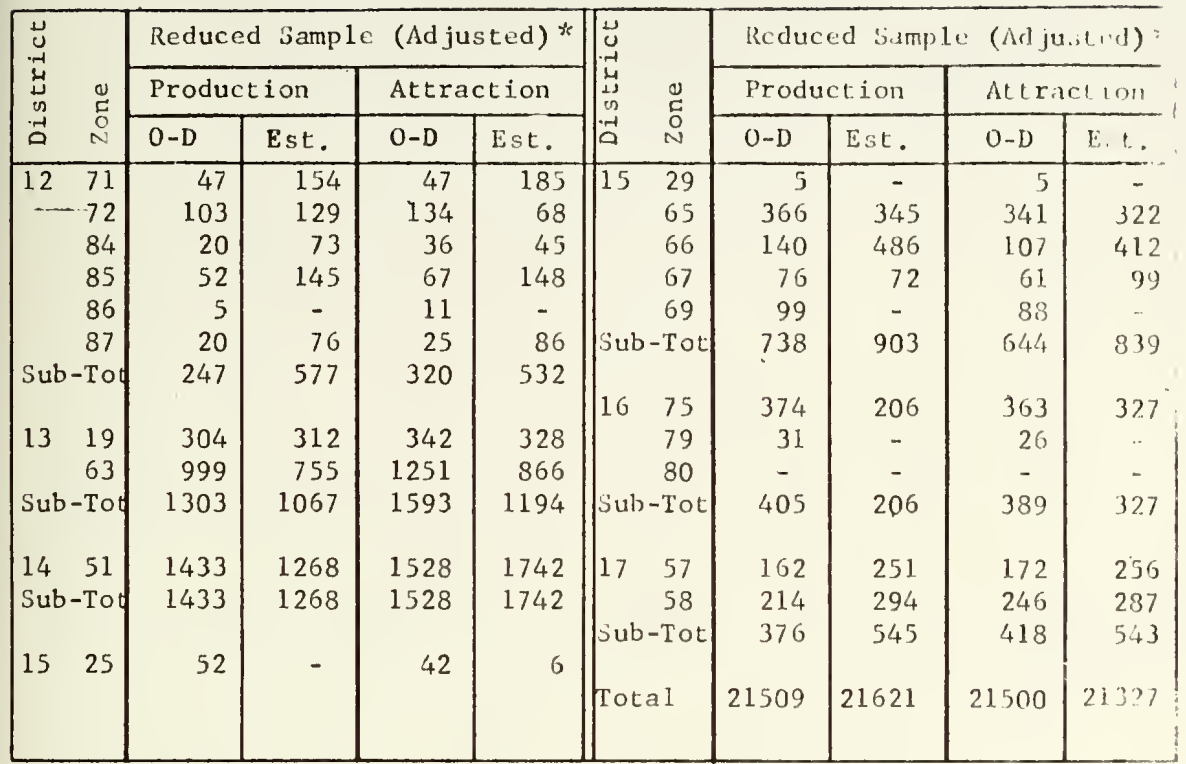

* O-D total non-home productions and attractions were used to cxpind to zonal totals. In Table 24 estimated total non-home productions an attractions were used. 
Crossings of screenline 6 showed the largest per cent difference; however, the number of trips crossing the line was very small making it difficult to obtain a close agreement, percentage wise. It is believed, however, that this did indicate some geographical bias in the model and could probably have been remedied by increasing the terminal times in the zones south of screenline 6 or by applying zone to zone " $k$ " factors. The total number of trips, however, involved did not appear to warrant such adjusting procedures. Tables 26 through 29 compare the various screenline crossings.

\section{Trip Length Comparison}

It was felt that the comparison of the total amount of travel and average trip length as obtained from the various model distributions would serve as measurements of the adequacy of the model.

Figures 26 through 37 show the trip length frequency distribution, by purpose, of the O-D data versus the various model configurations. These comparisons show a very close agreement of the model and O-D data.

The comparisons of the average length of trip in minutes and total vehicle hours of travel are shown in Tables 30 and 31 and also indicate close agreement. The comparisons of the average length of trip in miles and total vehicle miles of travel are shown in Tables 32 and 33 and again indicate close agreement.

Since there were few diagonal streets in Hutchinson, the distance, in miles, between zone centroids was measured by determining the " $L$ " distance (sum of map coordinate differences) and the total 


\begin{tabular}{|c|c|c|c|c|c|c|c|c|c|}
\hline \multirow{4}{*}{ 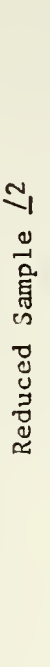 } & 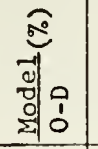 & $\stackrel{+}{\dot{0}}$ & $\begin{array}{l}\rightarrow \\
\infty \\
0 \\
0\end{array}$ & ம் & क. & $\begin{array}{l}t \\
0 \\
0\end{array}$ & $\stackrel{\sim}{\stackrel{n}{m}}$ & $\begin{array}{l}\sim \\
\stackrel{\sim}{=}\end{array}$ & 웅 \\
\hline & $\begin{array}{l} \pm \\
-1 \\
0 \\
0 \\
0 \\
0\end{array}$ & $\begin{array}{l} \pm \\
\infty \\
\infty \\
\stackrel{\sim}{\infty}\end{array}$ & $\begin{array}{l}\sim \\
\underset{N}{N} \\
\underset{N}{N}\end{array}$ & $\begin{array}{l}\text { ñ } \\
\text { on } \\
\infty \\
\text { N }\end{array}$ & 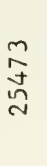 & $\begin{array}{l}\stackrel{0}{n} \\
\stackrel{n}{n} \\
\text { N }\end{array}$ & $\begin{array}{l}5 \\
0 \\
\text { in }\end{array}$ & $\begin{array}{l}\text { in } \\
\text { in } \\
\text { I- }\end{array}$ & $\begin{array}{l}\text { ô } \\
0 \\
0 \\
\text { iv } \\
\text { in }\end{array}$ \\
\hline & हैं & $\stackrel{-1}{\circ}$ & ㄱ. & "? & $\begin{array}{l}\infty \\
\infty \\
\infty\end{array}$ & ? & $\begin{array}{r}\vec{n} \\
\vec{\sim}\end{array}$ & $\stackrel{-a}{a}$ & ई. \\
\hline & $\begin{array}{l}m \\
-1 \\
-0 \\
\tilde{D}^{-1}\end{array}$ & $\begin{array}{l}\vec{b} \\
\infty \\
\end{array}$ & $\underset{n}{\stackrel{n}{n}}$ & $\begin{array}{l}\infty \\
0 \\
\text { D } \\
\text { N }\end{array}$ & \begin{tabular}{l}
0 \\
\multirow{1}{*}{} \\
\multirow{2}{*}{}
\end{tabular} & \begin{tabular}{l}
9 \\
\multirow{1}{*}{} \\
0 \\
N
\end{tabular} & 㔯 & m & $\begin{array}{l} \pm \\
\infty \\
= \\
\exists \\
\pm \\
-1\end{array}$ \\
\hline \multirow{4}{*}{ 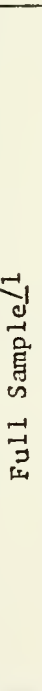 } & 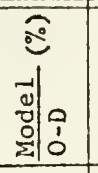 & $\begin{array}{l}0 \\
\infty \\
0 \\
0\end{array}$ & $\stackrel{0}{0}$ & $\begin{array}{l}-1 \\
\stackrel{1}{0} \\
\stackrel{-}{-1}\end{array}$ & $\stackrel{r}{\mathfrak{r}}$ & $\begin{array}{l}\infty \\
\stackrel{\circ}{\circ} \\
\stackrel{-1}{ }\end{array}$ & $\begin{array}{l}\overrightarrow{0} \\
\stackrel{m}{\rightarrow}\end{array}$ & $\underset{\sim}{\stackrel{N}{\sim}}$ & $\begin{array}{l}0 \\
0 \\
0\end{array}$ \\
\hline & 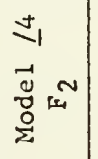 & $\begin{array}{l}\text { à } \\
\text { ă } \\
\text { à }\end{array}$ & $\begin{array}{c}\text { ले } \\
\frac{n}{N}\end{array}$ & $\begin{array}{l}\infty \\
+ \\
\sim \\
\infty \\
\sim \\
\sim\end{array}$ & $\begin{array}{l}\text { నू } \\
\text { กิ }\end{array}$ & \begin{tabular}{l}
7 \\
\multirow{1}{*}{} \\
0 \\
i
\end{tabular} & $\begin{array}{l}\text { O } \\
\text { in }\end{array}$ & 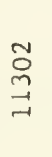 & 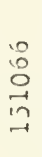 \\
\hline & 욜. & ra & $\stackrel{0}{\stackrel{0}{0}}$ & $\begin{array}{l}0 \\
2\end{array}$ & $\begin{array}{l}a \\
a\end{array}$ & $\stackrel{m}{a}$ & $\ddot{\sim}$ & ?ं & o \\
\hline & 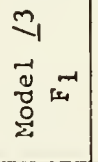 & \begin{tabular}{l}
$\infty$ \\
\multirow{N}{N}{} \\
$N$
\end{tabular} & $\begin{array}{l}0 \\
\text { वे } \\
\text { ô } \\
\text { N }\end{array}$ & $\begin{array}{l}\stackrel{a}{ } \\
\text { Iै } \\
\stackrel{5}{\sim}\end{array}$ & $\begin{array}{l}\infty \\
8 \\
\stackrel{0}{ \pm} \\
\text { N }\end{array}$ & $\begin{array}{l}\text { in } \\
\text { D } \\
\text { Iే } \\
\stackrel{+}{N}\end{array}$ & $\stackrel{n}{i n}$ & $\begin{array}{l}N \\
\text { क } \\
0 \\
\sigma\end{array}$ & $\begin{array}{l}\overrightarrow{+} \\
\stackrel{+}{ \pm} \\
\infty \\
ٍ \\
\sim\end{array}$ \\
\hline \multicolumn{2}{|c|}{ 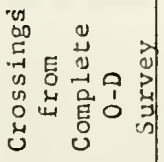 } & $\begin{array}{l}\text { Jै } \\
\stackrel{n}{N} \\
\text { ñ }\end{array}$ & $\begin{array}{l}\text { in } \\
\text { â } \\
\text { iv }\end{array}$ & $\begin{array}{l}0 \\
\text { in } \\
\text { N }\end{array}$ & $\begin{array}{l}\text { O } \\
\text { ñ } \\
\text { N }\end{array}$ & $\begin{array}{l}\infty \\
\text { N } \\
\infty \\
\text { N } \\
\text { N }\end{array}$ & $\begin{array}{l}\text { O } \\
\text { ָ } \\
\text { J }\end{array}$ & $\begin{array}{l}\infty \\
\stackrel{\sim}{O} \\
O \\
O\end{array}$ & 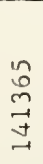 \\
\hline \multicolumn{2}{|c|}{$\begin{array}{c}\text { әuTฺ } \\
\text { - นәวגวs }\end{array}$} & जा & $\sim$ & $m$ & at & n & 0 & $n$ & 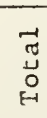 \\
\hline
\end{tabular}

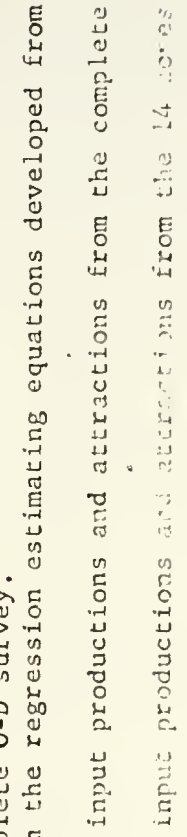

है E $\overrightarrow{\text { E }}$

ठै

ब 규

돋ㄷㄴ

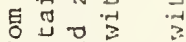

मे 이

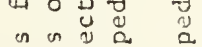

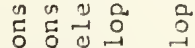

$\rightarrow-\rightarrow$ क व

㟧士 嵌?

$\pi \pi \rightarrow-7$

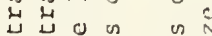

4

तथ 13 क

च् च U U

(1) W!

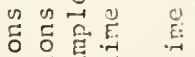

*1 $\rightarrow$ ह

y

चे पु $\Rightarrow$

० 0 प के

口四出?

00 th

E $E C=$

जी जो की

DD 50 . 


\begin{tabular}{|c|c|c|c|c|c|c|c|c|c|}
\hline \multirow{4}{*}{ 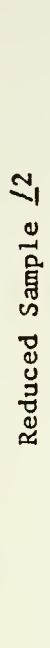 } & है & $\begin{array}{l}0 \\
0 \\
-1\end{array}$ & $\begin{array}{l}\infty \\
\dot{y} \\
\vec{y}\end{array}$ & - & á & ்ָ & \begin{tabular}{l}
$a$ \\
0 \\
\multirow{1}{1}{}
\end{tabular} & $\begin{array}{l}0 \\
0 \\
=1\end{array}$ & $\stackrel{\sim}{\circ}$ \\
\hline & 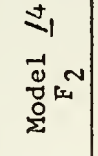 & $\stackrel{\infty}{\stackrel{\infty}{*}}$ & $\begin{array}{l}\text { 응 } \\
\text { 6 }\end{array}$ & $\begin{array}{l}n \\
\stackrel{0}{n} \\
\infty\end{array}$ & $\begin{array}{l}\text { v } \\
\text { v } \\
r\end{array}$ & $\begin{array}{l}1 \\
8 \\
\infty\end{array}$ & 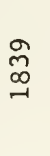 & $\begin{array}{l} \pm \\
\frac{1}{t}\end{array}$ & \begin{tabular}{l} 
nn \\
$\hat{b}$ \\
0 \\
\multirow{1}{*}{}
\end{tabular} \\
\hline & 尺ْ & गें & $\ddot{0}$ & ra & $\begin{array}{l}\mathscr{0} \\
\infty\end{array}$ & $\stackrel{t}{a}$ & $\stackrel{+}{a}$ & $\begin{array}{l}a \\
\text { a }\end{array}$ & जे \\
\hline & 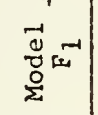 & $\underset{\infty}{n}$ & ָָ & 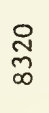 & $\begin{array}{l}9 \\
0 \\
0 \\
1\end{array}$ & 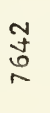 & $\begin{array}{l}0 \\
\stackrel{0}{ \pm} \\
\rightarrow\end{array}$ & Nָ & 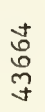 \\
\hline \multirow{4}{*}{ 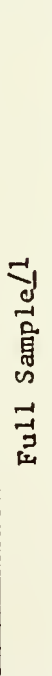 } & $\begin{array}{l}\text { 옹 } \\
-1 \\
0 \\
0 \\
2\end{array}$ & $\stackrel{\rightleftarrows}{\beth}$ & $\stackrel{-1}{0}$ & $\begin{array}{l}0 \\
\text { aे }\end{array}$ & - & $\stackrel{m}{0}$ & 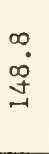 & $\stackrel{-1}{0}$ & O. \\
\hline & $\begin{array}{l} \pm \\
=1 \\
\overrightarrow{0} \\
\vec{D}^{N}\end{array}$ & in & \begin{tabular}{l}
\multirow{J}{0}{} \\
$\hat{\sigma}$
\end{tabular} & $\begin{array}{l}\hat{y} \\
\text { y }\end{array}$ & $\begin{array}{l}0 \\
\text { ஸ̃ } \\
\end{array}$ & 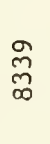 & $\begin{array}{c}\infty \\
m \\
\infty \\
-1\end{array}$ & $\underset{N}{N}$ & 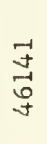 \\
\hline & 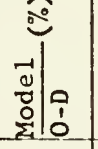 & $\underset{-1}{0}$ & $\begin{array}{l}+ \\
-1 \\
\stackrel{-}{-}\end{array}$ & $\stackrel{0}{\tilde{N}}$ & $\tilde{a}$ & ñ & 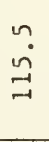 & $\check{n}$ & $\begin{array}{l}+ \\
\infty \\
\sigma\end{array}$ \\
\hline & 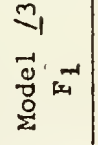 & $\vec{m}$ & స్ & $\underset{\tilde{N}}{\stackrel{\tilde{J}}{\infty}}$ & $\stackrel{\Re}{n}$ & $\underset{v}{ \pm}$ & $\underset{N}{ \pm}$ & \begin{tabular}{l}
0 \\
\multirow{1}{*}{} \\
m
\end{tabular} & $\begin{array}{l}\tilde{n} \\
\tilde{y} \\
y\end{array}$ \\
\hline \multicolumn{2}{|c|}{ 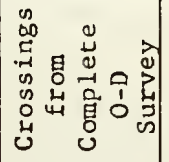 } & $\begin{array}{l}\hat{0} \\
\text { ก } \\
\infty\end{array}$ & 운 & $\begin{array}{l}\infty \\
0 \\
\infty \\
\infty\end{array}$ & $\stackrel{ \pm}{N}$ & \begin{tabular}{l}
\multirow{J}{*}{} \\
\multirow{1}{*}{} \\
0
\end{tabular} & $\stackrel{n}{n}$ & $\begin{array}{l}\stackrel{\circ}{n} \\
\text { m }\end{array}$ & 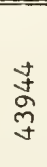 \\
\hline \multicolumn{2}{|c|}{ 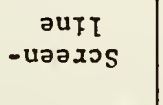 } & $\prod_{-1}^{\pi}$ & $N$ & m & $\checkmark$ & in & 0 & $N$ & تే \\
\hline
\end{tabular}

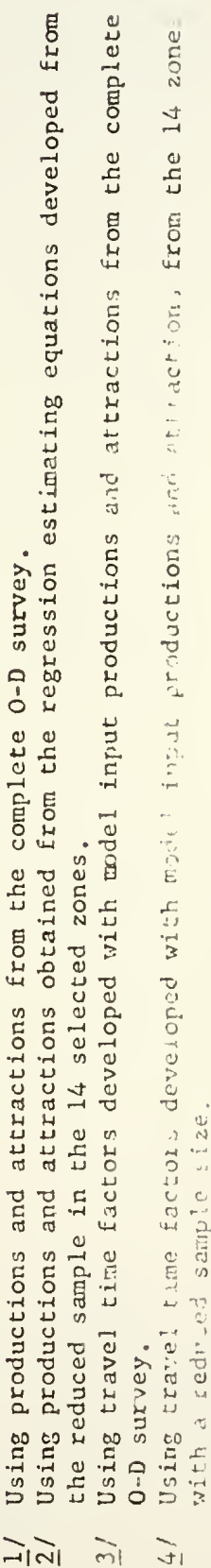




\begin{tabular}{|c|c|c|c|c|c|c|c|c|c|}
\hline \multirow{4}{*}{ 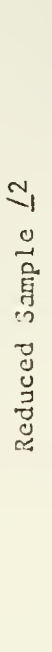 } & 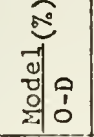 & $\stackrel{r}{0}$ & $\stackrel{m}{9}$ & $\begin{array}{l}0 \\
\infty \\
0 \\
0-1\end{array}$ & $\begin{array}{l}- \\
\dot{0} \\
\overrightarrow{1}\end{array}$ & $\begin{array}{l}a \\
\text { j } \\
0\end{array}$ & $\stackrel{m}{\dot{m}}$ & $\begin{array}{l}0 \\
10 \\
\stackrel{1}{-1}\end{array}$ & $\begin{array}{l}N \\
\infty \\
0 \\
0\end{array}$ \\
\hline & 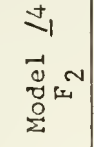 & $\tilde{n}_{0}^{N}$ & $\begin{array}{l}0 \\
\text {-1 } \\
\infty \\
\sigma\end{array}$ & $\begin{array}{l}\text { से } \\
\text { Dे } \\
\text { I } \\
\text {-1 }\end{array}$ & $\begin{array}{l}\text { o } \\
\text { in } \\
=\end{array}$ & 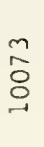 & $\stackrel{\mathscr{N}}{\sim}$ & 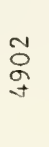 & $\begin{array}{l}0 \\
0 \\
0 \\
10\end{array}$ \\
\hline & 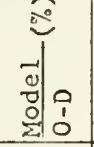 & ?. & $\stackrel{2}{0}$ & $\frac{a}{5}$ & a. & N & $\underset{\sim}{\stackrel{\sigma}{\sim}}$ & $\begin{array}{l}t \\
\text { in }\end{array}$ & $\stackrel{0}{\circ}$ \\
\hline & $\begin{array}{l}m \\
-1 \\
\overrightarrow{0} \\
\vec{D}_{z}^{-1}\end{array}$ & $\begin{array}{l}0 \\
8 \\
8 \\
0\end{array}$ & $\begin{array}{l}\text { N } \\
\text { N }\end{array}$ & 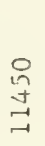 & $\begin{array}{l}8 \\
0 \\
11 \\
0 \\
-1\end{array}$ & $\begin{array}{l}\text { in } \\
\text { o } \\
\text { ŏ }\end{array}$ & $\begin{array}{l}\infty \\
\stackrel{N}{N} \\
-1\end{array}$ & 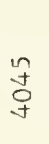 & $\begin{array}{l}\hat{N} \\
0 \\
\text { in }\end{array}$ \\
\hline \multirow{4}{*}{ 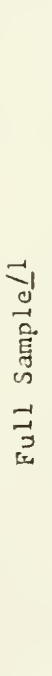 } & $\begin{array}{c}\text { ล0 } \\
-1 \\
0 \\
0 \\
0\end{array}$ & $\stackrel{\sim}{\dot{y}}$ & $\begin{array}{l}N \\
0 \\
0 \\
0\end{array}$ & $\begin{array}{l}0 \\
0 \\
0\end{array}$ & $\begin{array}{l}\infty \\
\stackrel{0}{=} \\
=1\end{array}$ & : & $\stackrel{+}{\vec{m}}$ & 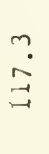 & $\stackrel{+}{\circ}$ \\
\hline & 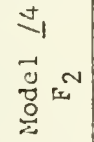 & $\begin{array}{l}n \\
i n \\
0 \\
0\end{array}$ & $\begin{array}{l}5 \\
0 \\
0\end{array}$ & $\begin{array}{l}\infty \\
\stackrel{2}{\sim} \\
\stackrel{-1}{-1}\end{array}$ & $\begin{array}{l}\text { 吉 } \\
\stackrel{+}{ \pm} \\
\text { 二 }\end{array}$ & $\begin{array}{l}\text { o } \\
\text { of } \\
\text { a }\end{array}$ & N & $\begin{array}{l}\vec{a} \\
\text { a }\end{array}$ & $\begin{array}{l}\stackrel{b}{N} \\
\underset{\sigma}{*}\end{array}$ \\
\hline & 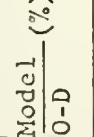 & $\stackrel{0}{\sigma}$ & $\underset{j}{0}$ & $\ddot{0}$ & $\begin{array}{l}+ \\
\infty \\
\sigma\end{array}$ & $\stackrel{9}{n}$ & $\stackrel{-}{\stackrel{\sim}{\sigma}}$ & ํ. & $\begin{array}{l}0 \\
\dot{\sigma}\end{array}$ \\
\hline & $\begin{array}{l}m \\
-1 \\
-1 \\
0 \\
0 \\
0 \\
2\end{array}$ & $\begin{array}{l}0 \\
\sigma \\
\sigma\end{array}$ & $\begin{array}{l}\text { No } \\
\vec{\sigma}\end{array}$ & $\begin{array}{l}a \\
\infty \\
\stackrel{\Xi}{\Xi} \\
=1\end{array}$ & \begin{tabular}{c}
$N$ \\
\multirow{1}{*}{} \\
0 \\
0
\end{tabular} & $\begin{array}{l}\infty \\
\infty \\
\cdots\end{array}$ & 감 & \begin{tabular}{l}
5 \\
0 \\
\multirow{1}{*}{}
\end{tabular} & $\begin{array}{l}\text { N } \\
\text { On } \\
\text { in }\end{array}$ \\
\hline \multicolumn{2}{|c|}{ 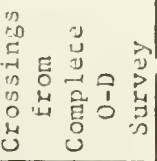 } & $\begin{array}{l}\text { ๙n } \\
\text { ๙ิ }\end{array}$ & $\begin{array}{l}\text { O } \\
\text { O }\end{array}$ & $\begin{array}{l}\text { aे } \\
\stackrel{0}{0} \\
=\end{array}$ & $\begin{array}{l}9 \\
0 \\
10 \\
0\end{array}$ & $\begin{array}{l}n \\
\infty \\
1 \\
\sigma\end{array}$ & $\stackrel{\vec{n}}{n}$ & 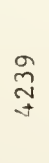 & $\begin{array}{l}a \\
\vec{a} \\
0 \\
\text { in }\end{array}$ \\
\hline \multicolumn{2}{|c|}{ 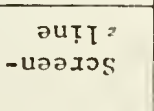 } & In & $N$ & $m$ & $\checkmark$ & in & 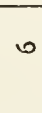 & $r$ & 常 \\
\hline
\end{tabular}

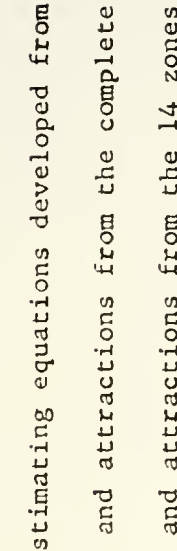

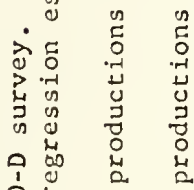

さّ

苨 :

है

ठ․

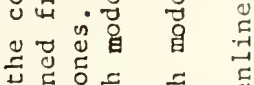

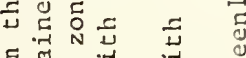
ह 的荙芩

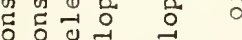

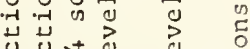
प्र मू ๗ँ चृ च्ञ

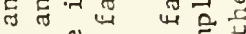

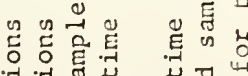

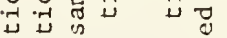
ठّ चै $0>0$ गे मे ค م

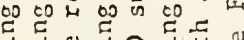

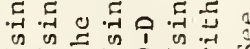

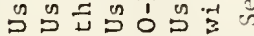
चौतो लो ॠा ख्या 


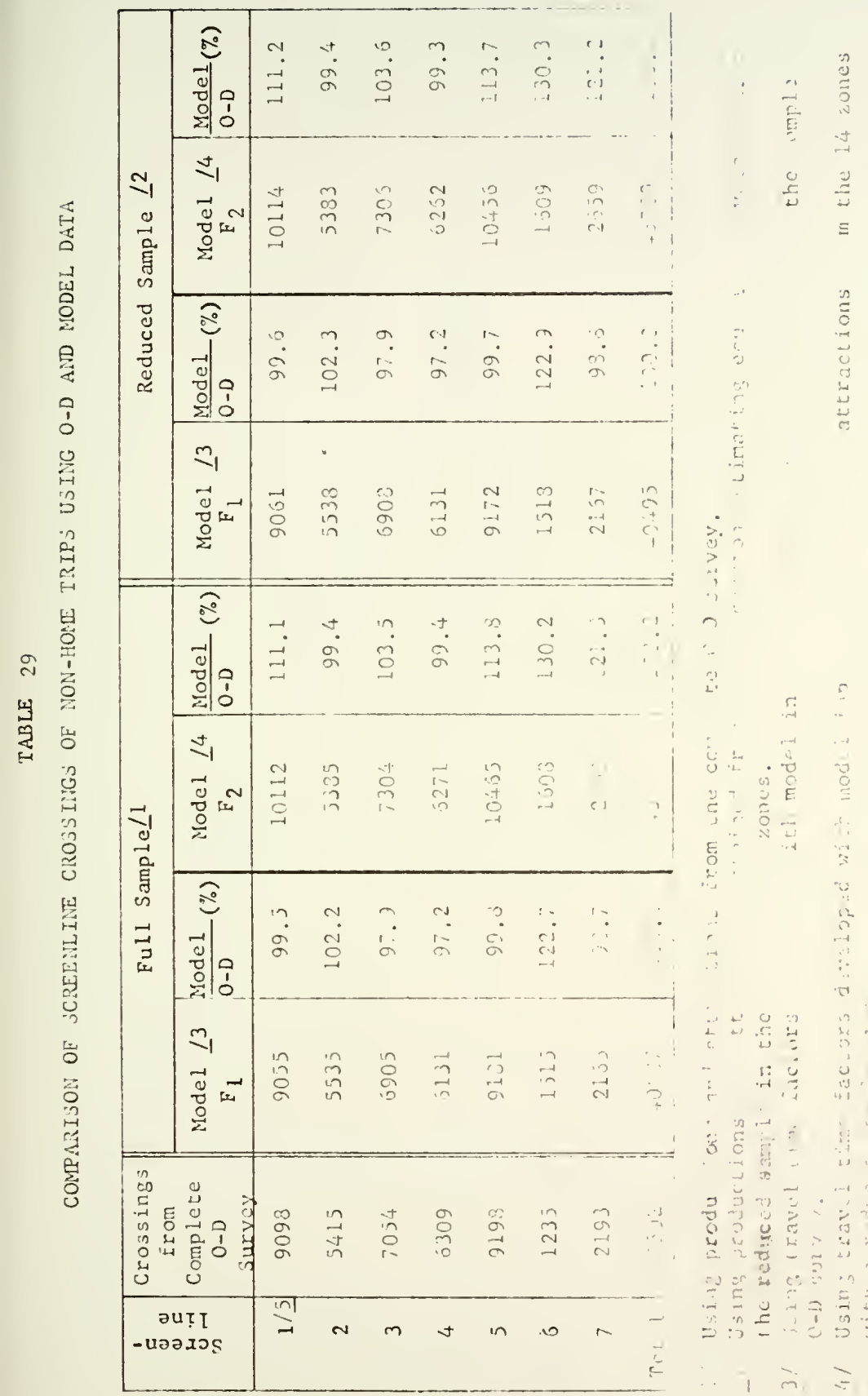




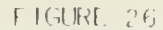

COMPARISON OF TRIP I H NGTH FREQLIENCY IK, INV, $11.11,1.1$

HME-WIRK TRIPS - COMBINATION 1 FARAM II

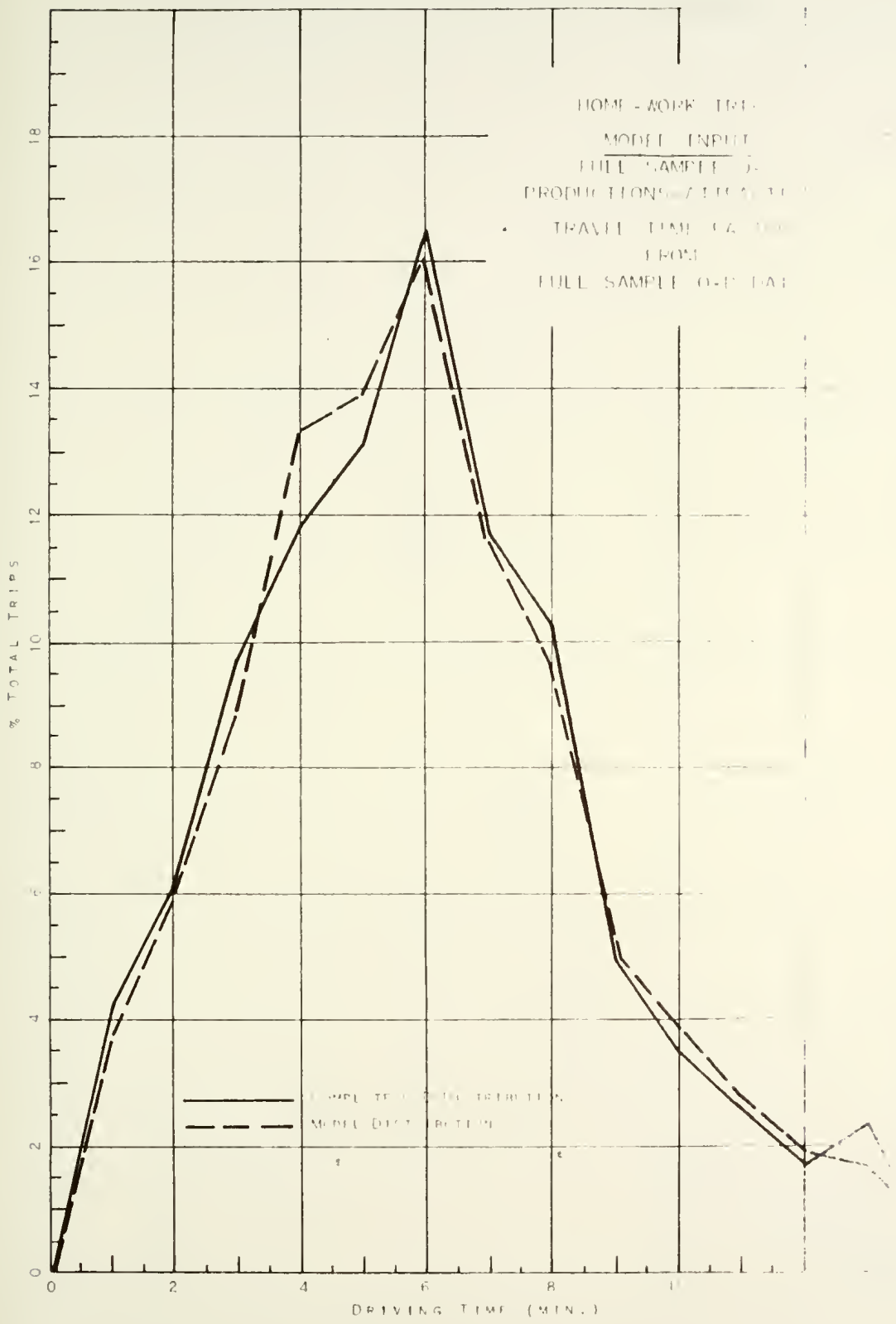


FIGURE $2 \%$

COMPARISON OF TRIP LENGTH FREQUENCY USING O-D AND MODEI DAIA HOME-OTHER TRIPS - COMBINATION I PARAMETERS

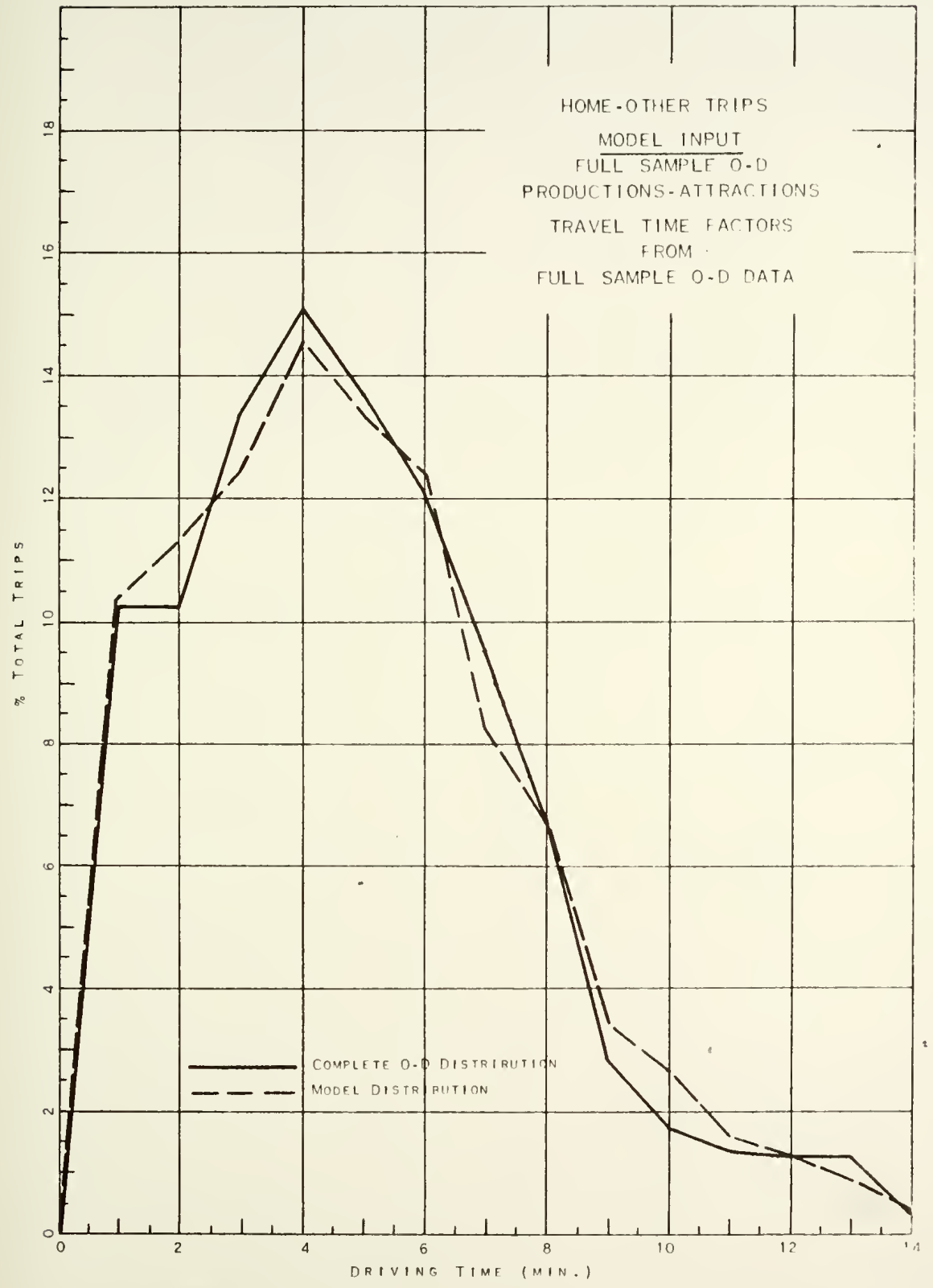


FICTRRE 28

COMPARISON OF TRIP I ENGTH FREDUENCY USING ()-I) AN W I I

NON-HOME TRIPS - COMRINAT ION I PARANF TERS

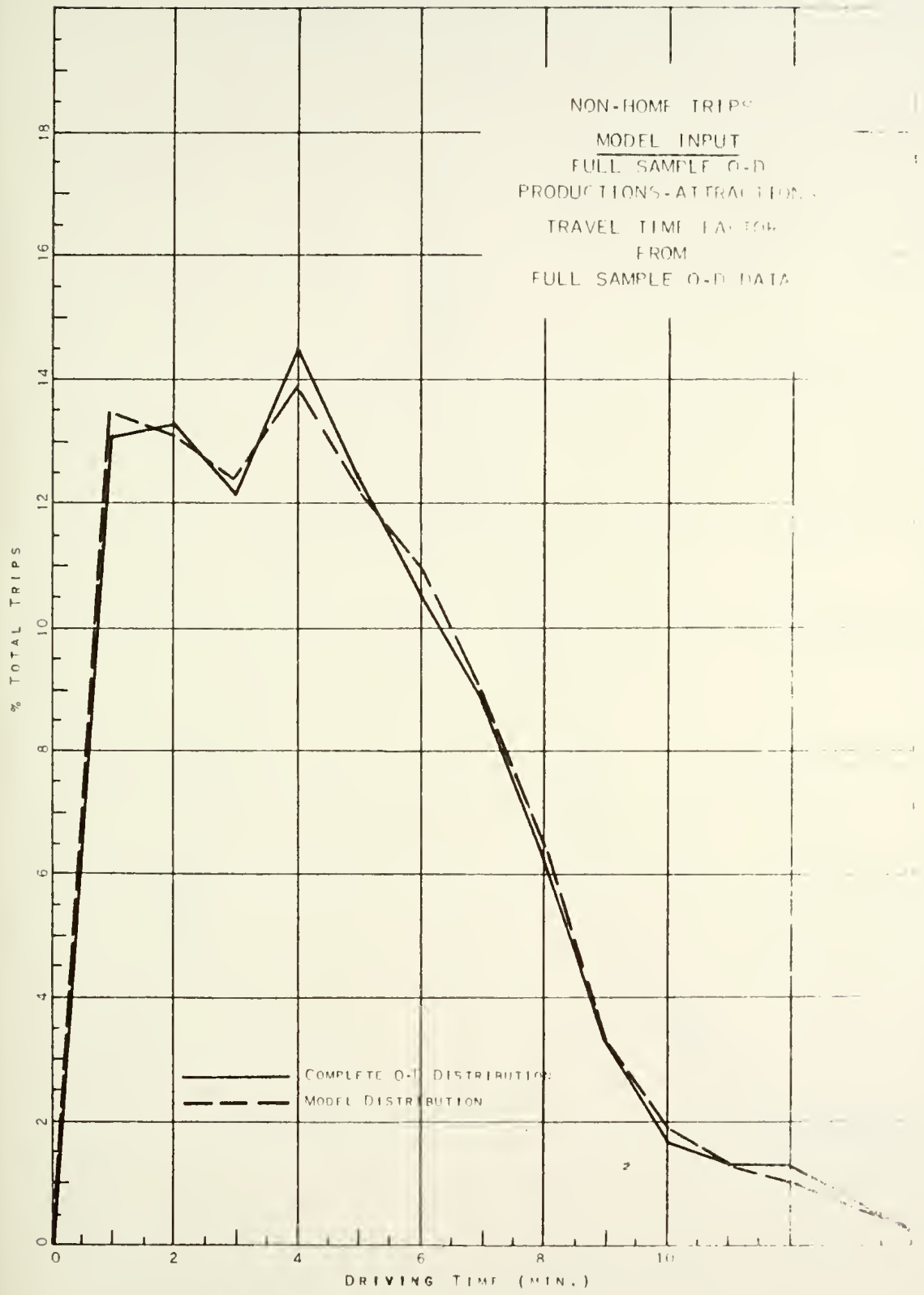


FIGURE 29

COMPARISON OF TRIP LENGTH FREQUENCY USING O-D AND MOOEL DATA HOME-WORK TRIPS - COMBINATION 2 PARAMETERS

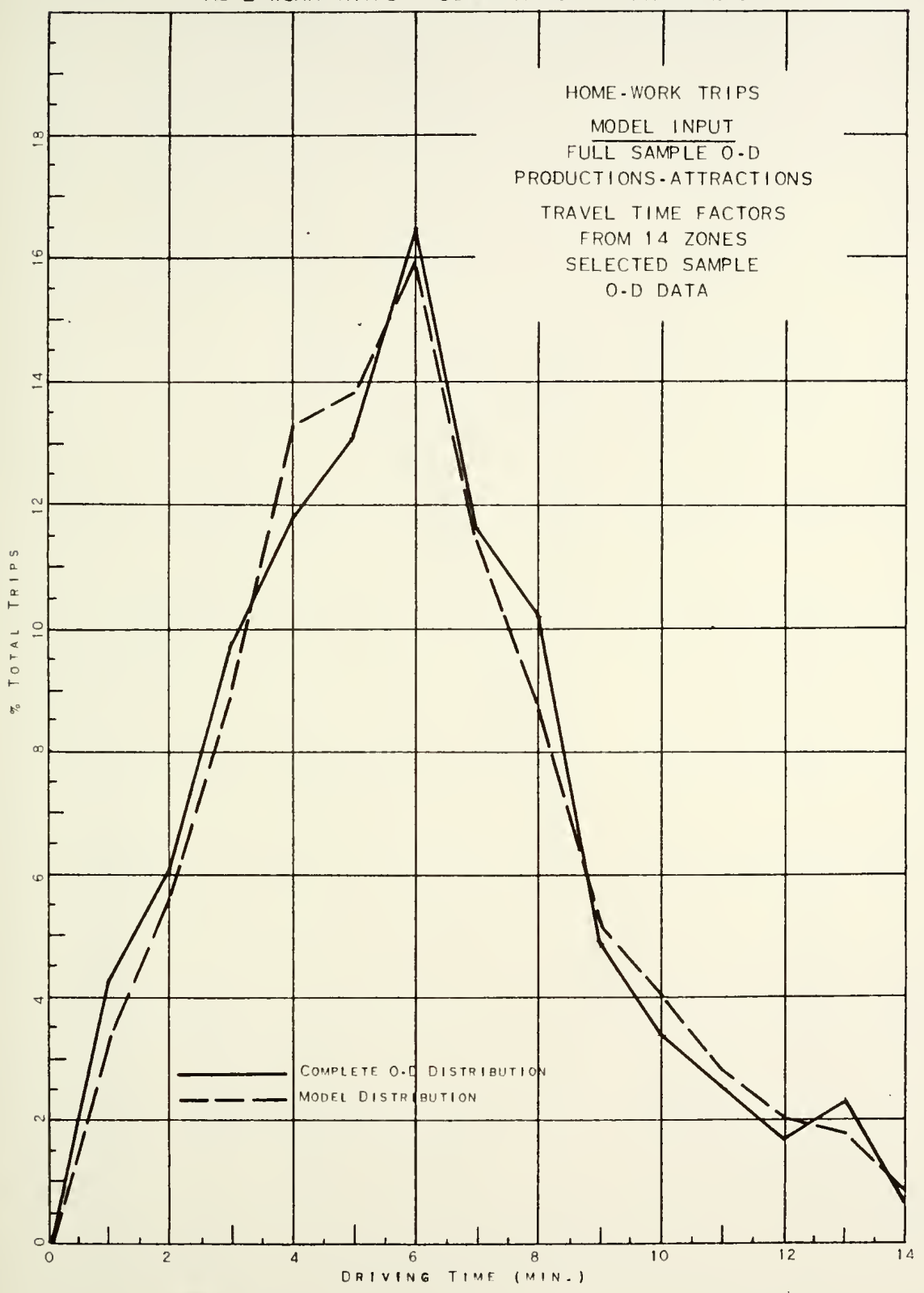


FIGURE 30

COMPARISON OF TRIP LENGTH FREQUENCY USING O-D AND MODEL DATA HOME-OTHER TRIPS - COMBINATION 2 PARAMETERS

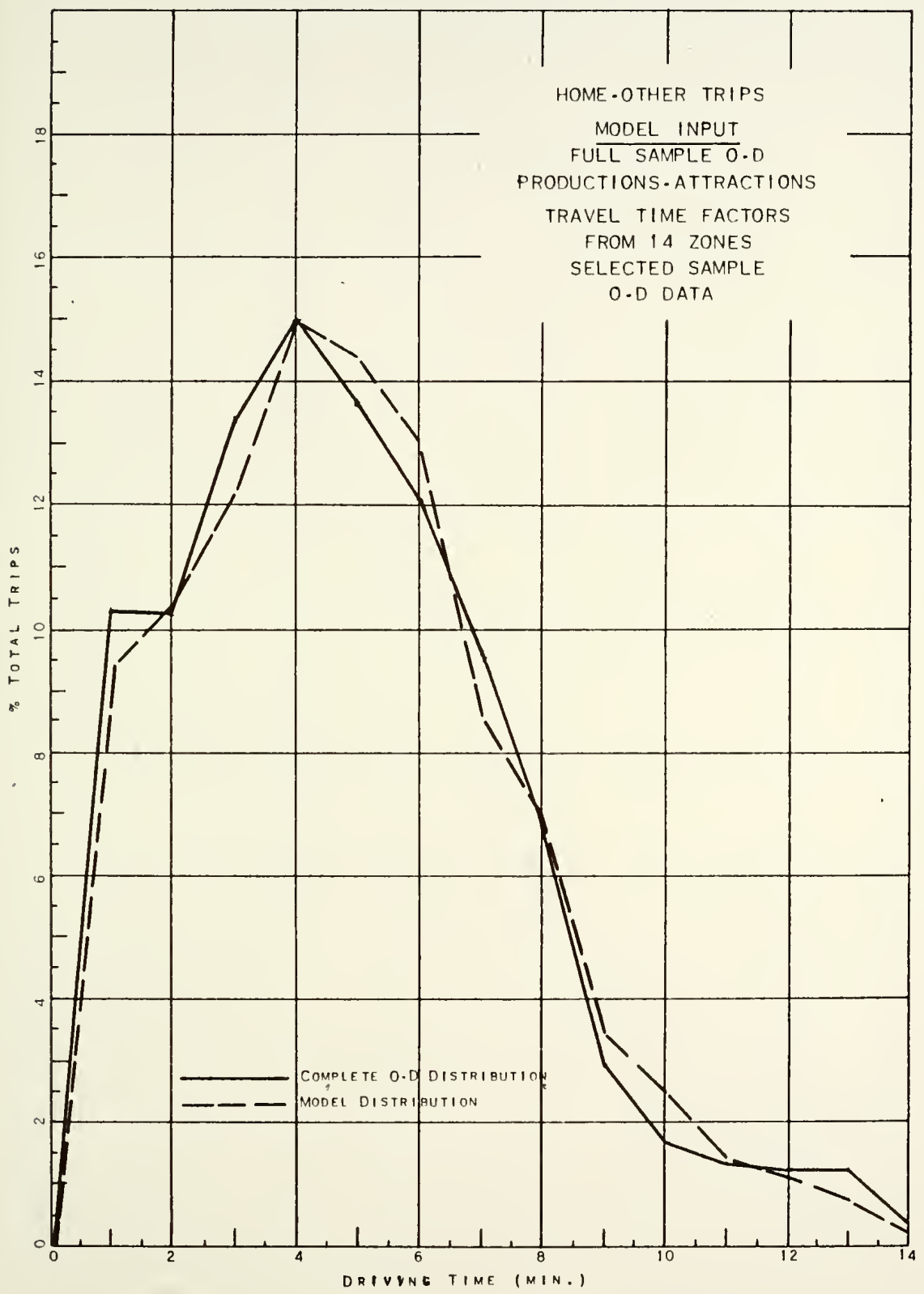


FIGURE 31

COMPARISON OF TRIP LENGTH FREOUENCY USING O-D AND MODEL DATA NON-HOME TRIPS - COMBINATION 2 PARAMETERS

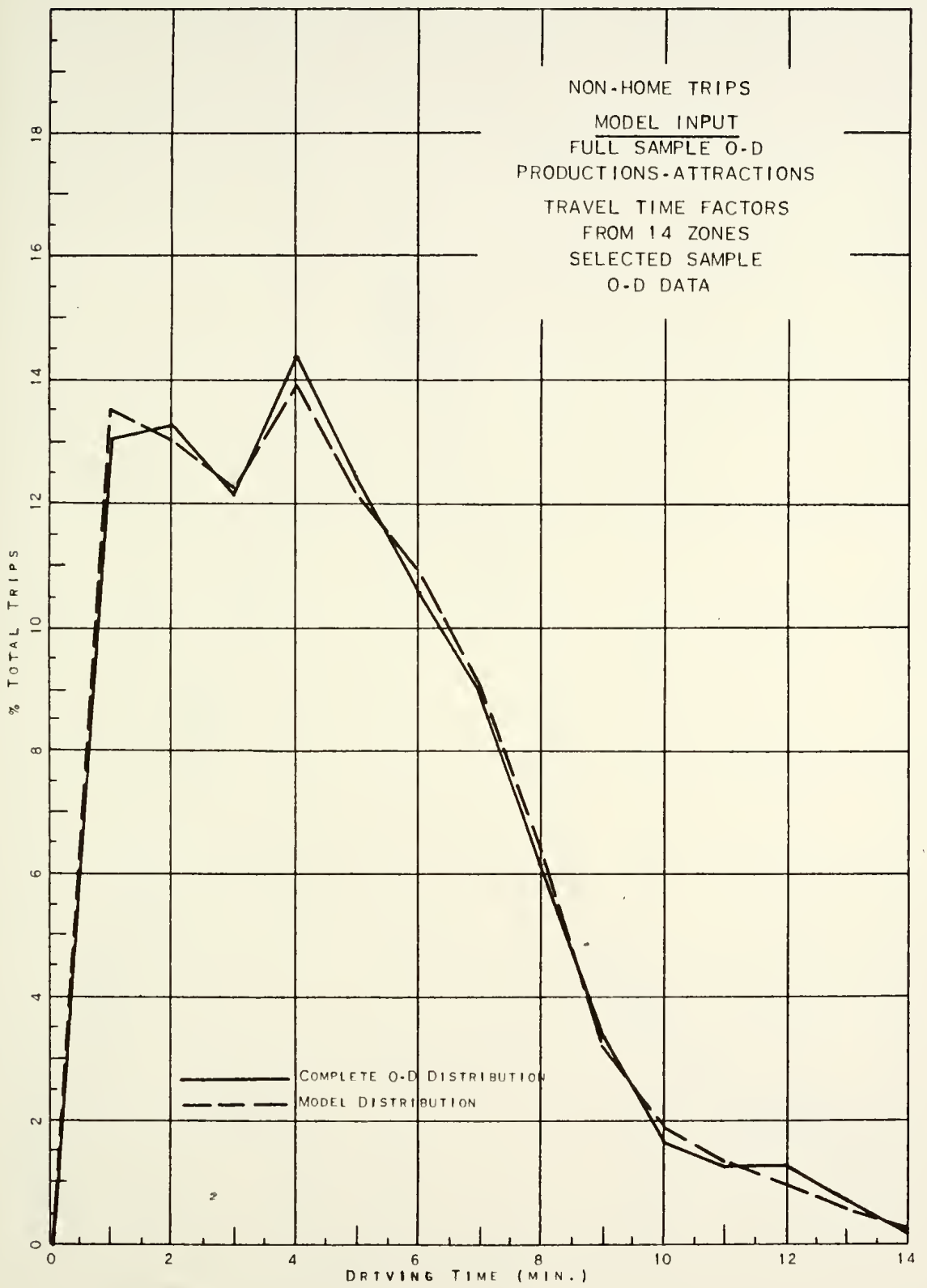


FIGURE 32

COMPARISON OF TRIP LENGTH FREQUENCY USING O-D AND MOOEL DATA HOME-WORK TRIPS - COMBINATION 3 PARAMETERS

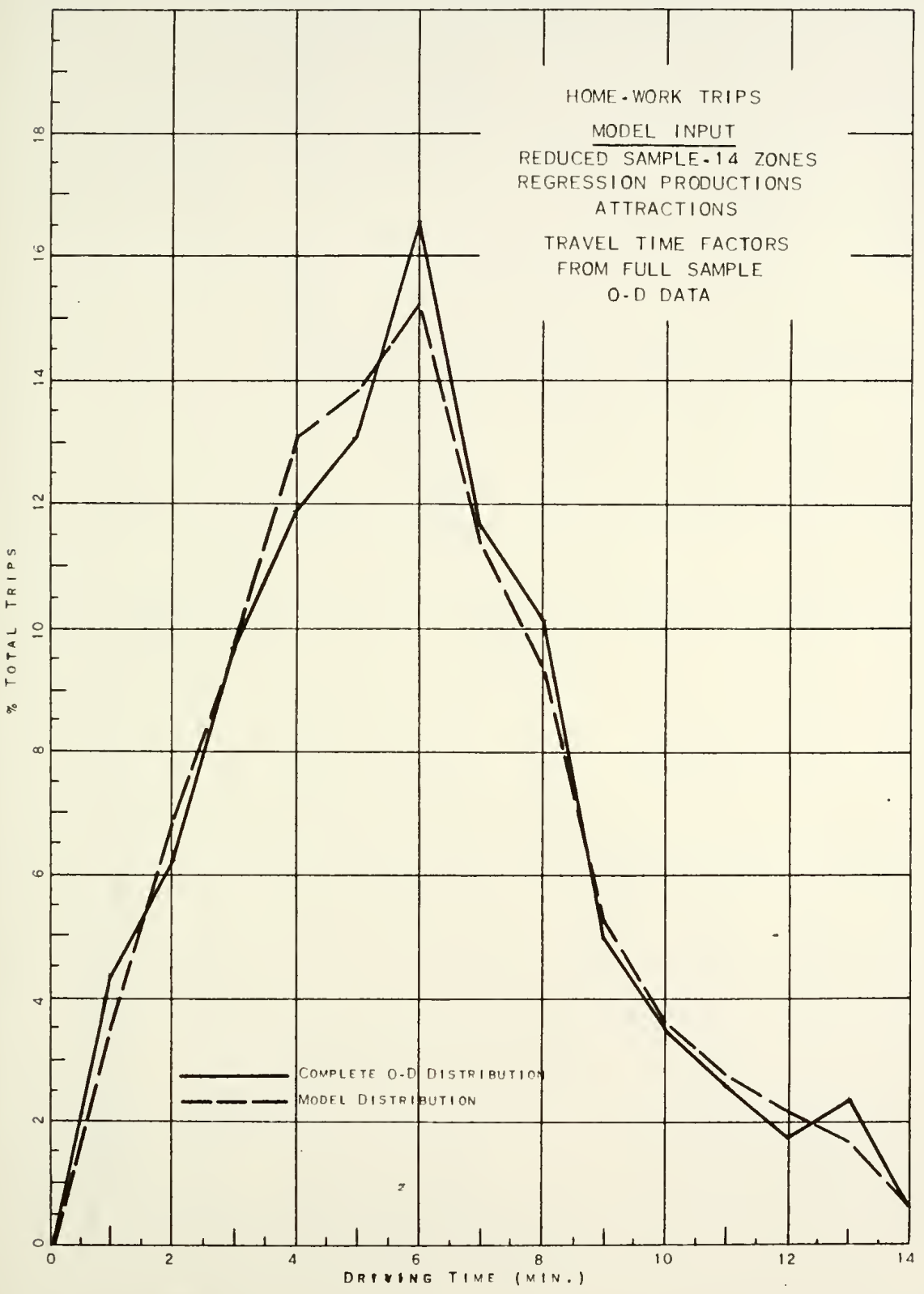


FIGURE 33

COMPARISON OF TRIP LENGTH FREOUENCY USING O-D AND MODEL DATA HOME-OTHER TRIPS - COMBINATION 3 PARAMETERS

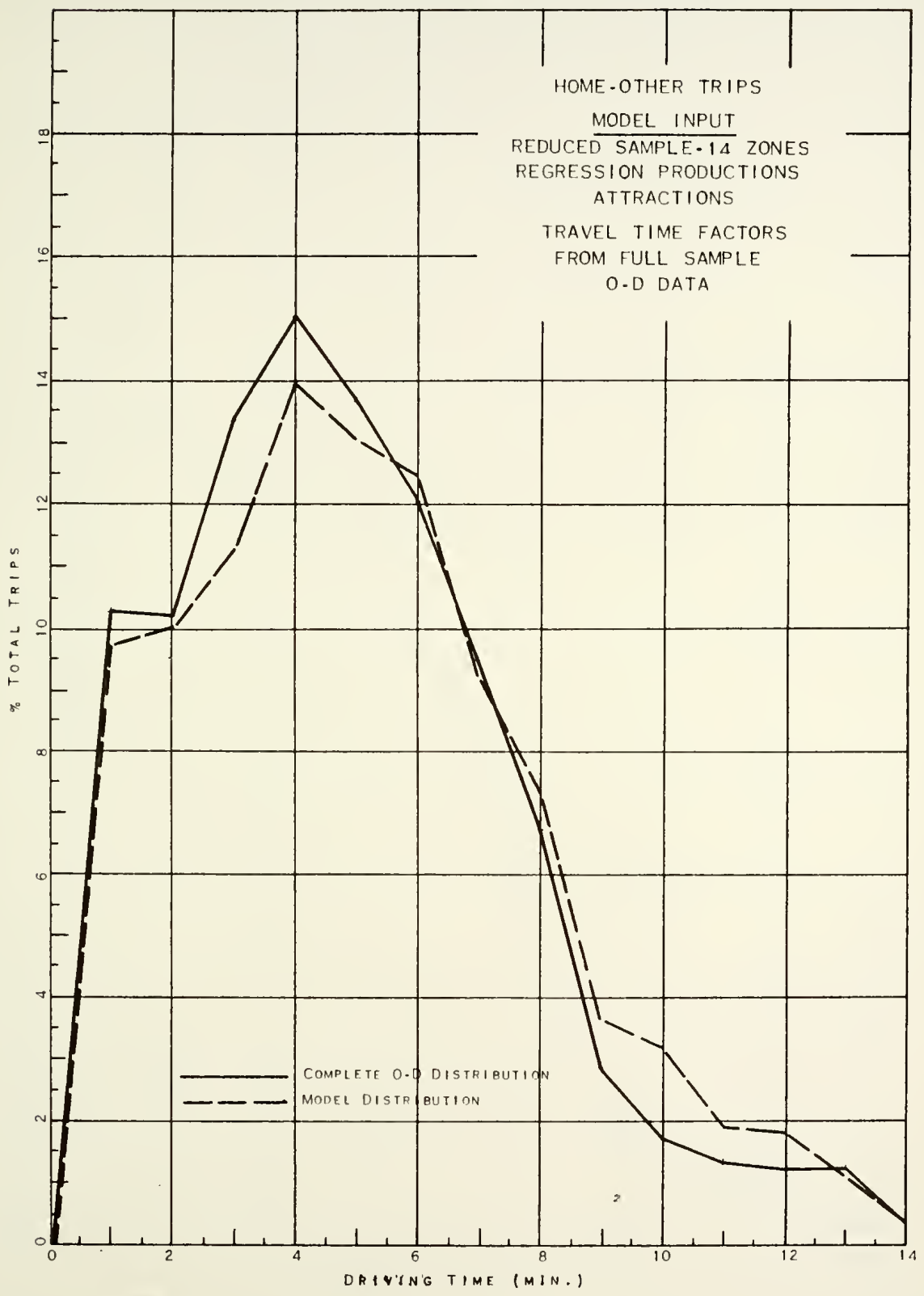


FIGURE 34

COMPARISON OF TRIP LENGTH FREQUENCY USING O-D AND MODEL DATA

NON-HOME TRIPS - COMINATION 3 PARAMETERS

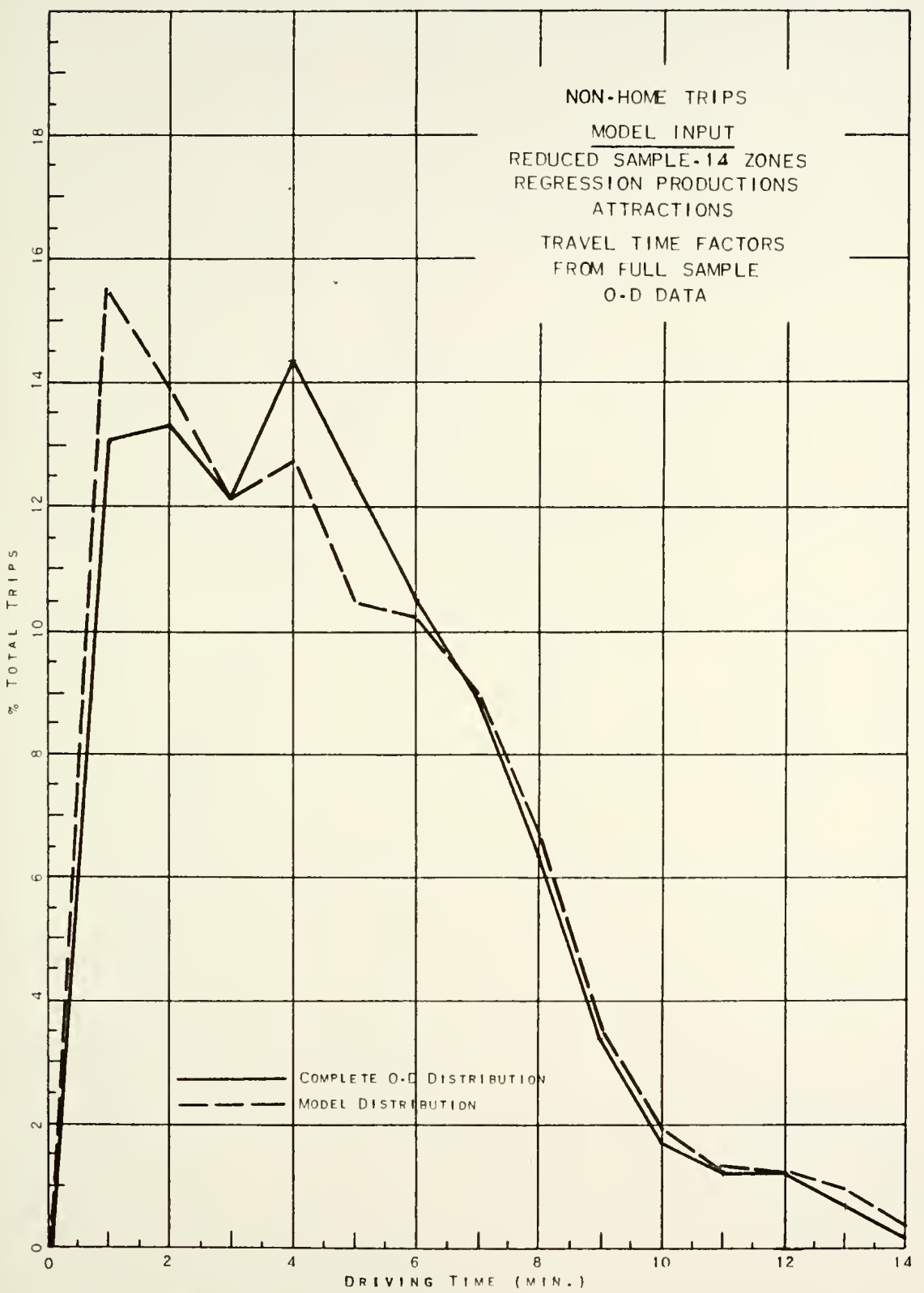


FIGURE 35

COMPARISON OF TRIP LENGTH FRECUENCY USING O-D AND MODEL DATA HOME-WORK TRIPS - COMBINATION 4 PARAMETERS

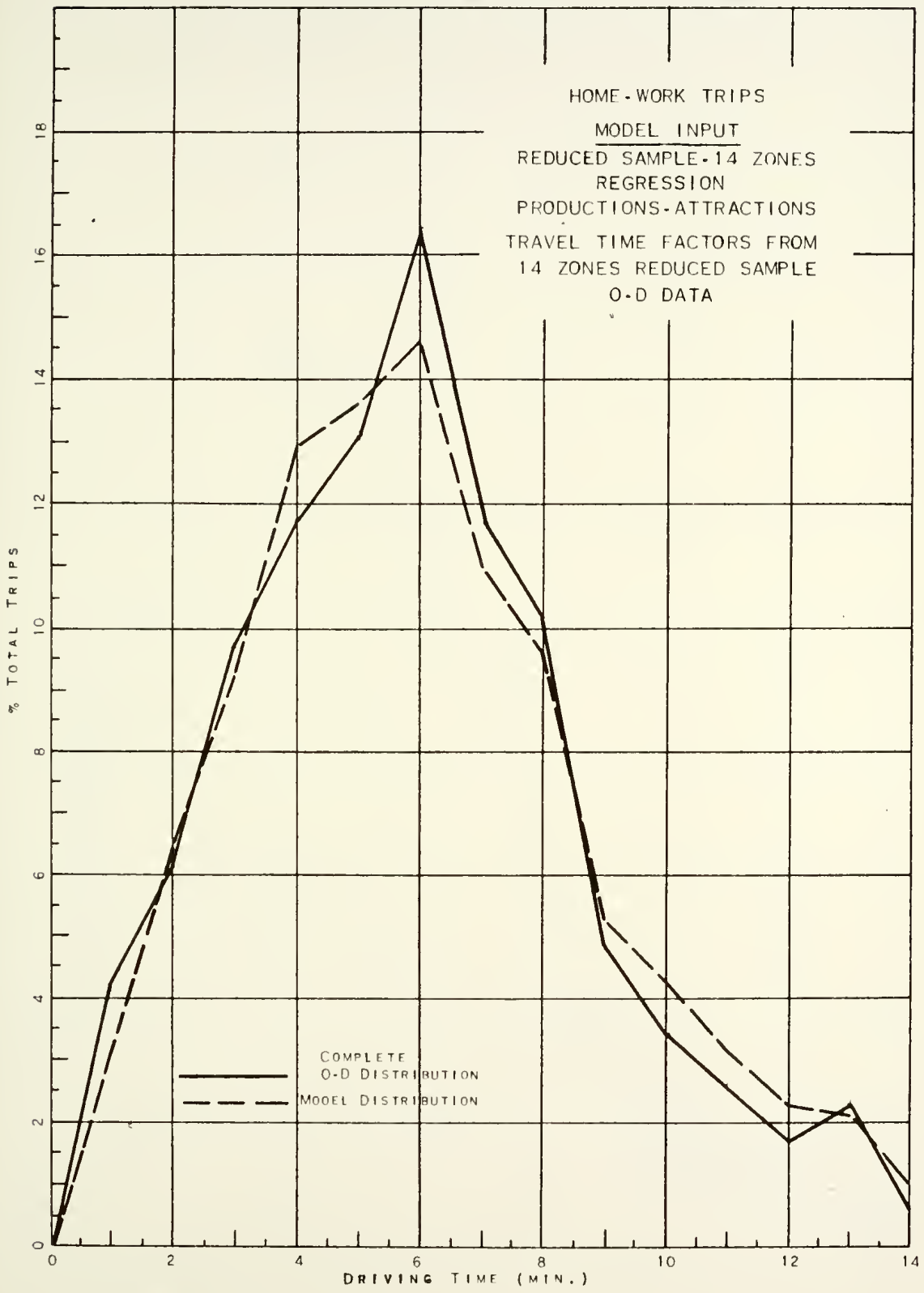


FIGURE 36

COMPARISON OF TRIP LENGTH FREQUENCY USING O-D AND MODEL DATA HOME-OTHER TRIPS - COMBINATION 4 PARAMETERS

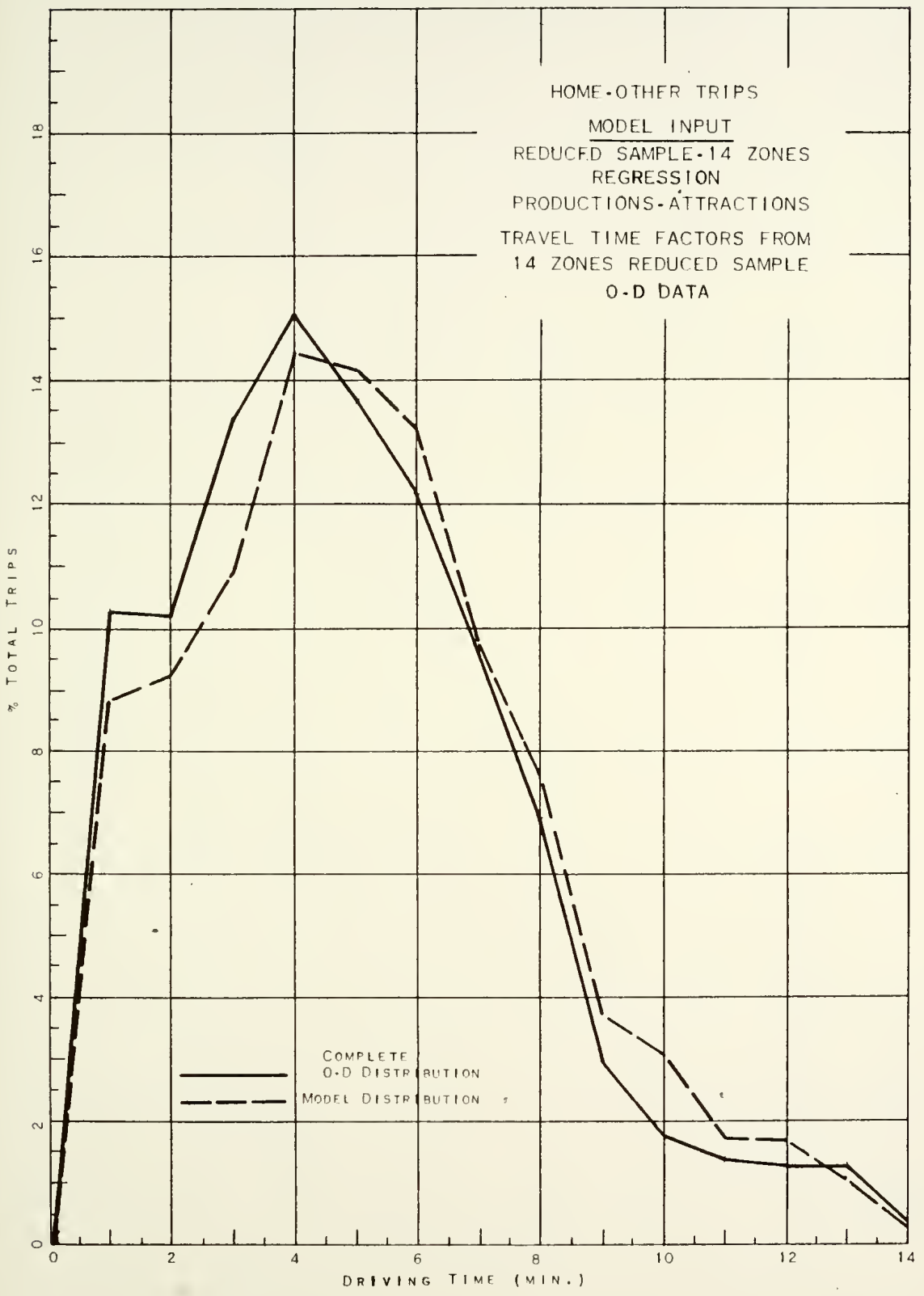


FIGURE 37

COMPARISON OF TRIP LENGTH FREQUENCY USING O-D AND MOOEL DATA NON-HOME TRIPS - COMBINATION 4 PARAMETERS

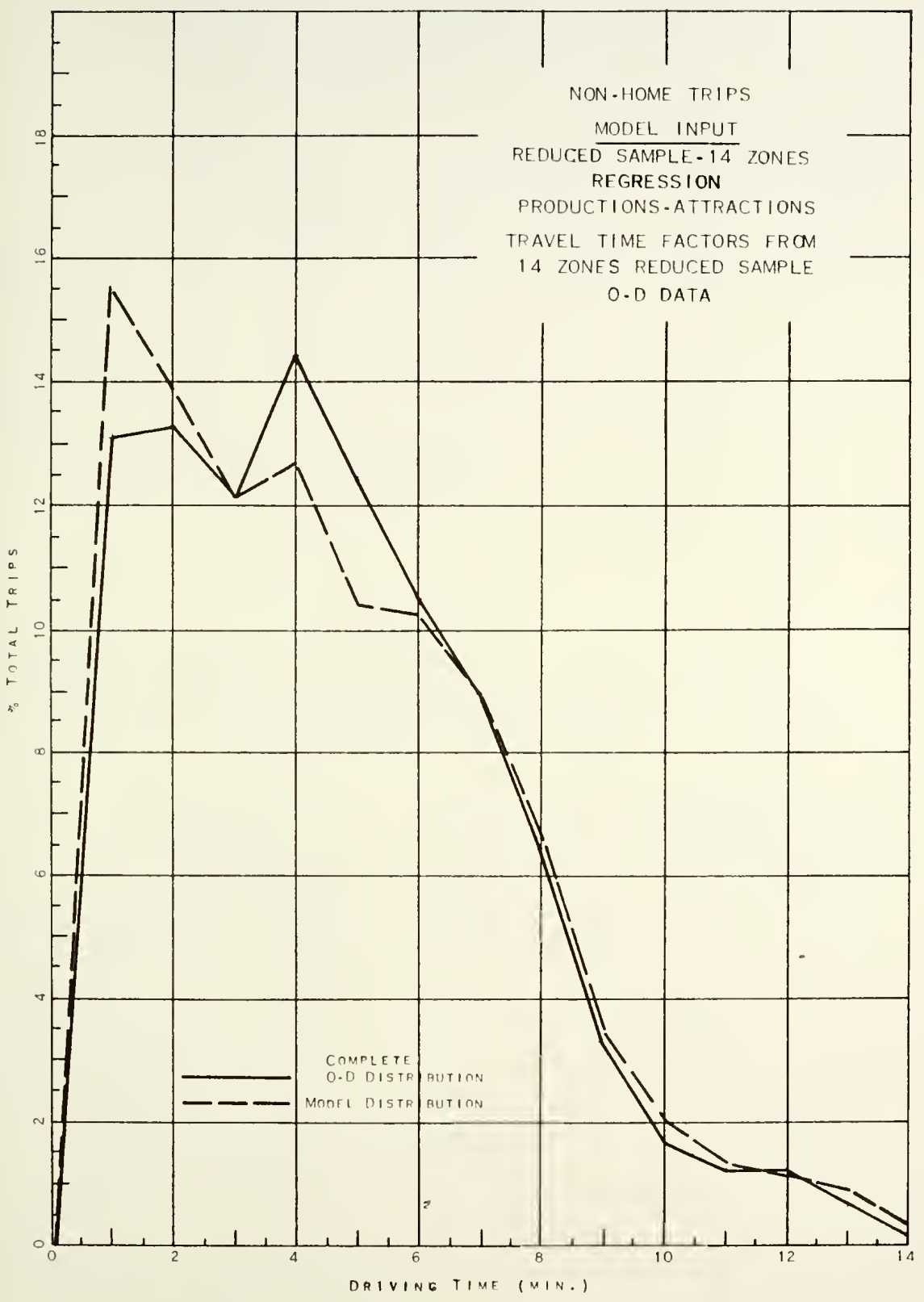


TABLE 30

COMPARISON OF VEHICLE HOURS OF TRAVEL AND AVERAGE TRIP LENGTH FROM O-D AND MODEL DATA USING TRAVEL TIME FACTORS FROM THE FULL SAMPLE O-D DATA

\begin{tabular}{|c|c|c|c|c|c|c|}
\hline \multirow[b]{3}{*}{$\begin{array}{l}\text { Trip } \\
\text { Purpose }\end{array}$} & \multirow{2}{*}{\multicolumn{2}{|c|}{$\begin{array}{l}\text { Complete } 0-D \\
\text { Survey Data }\end{array}$}} & \multicolumn{4}{|c|}{ Full Sample } \\
\hline & & & \multicolumn{2}{|c|}{$\begin{array}{l}\text { 0-D Productions- } \\
\text { Attractions }\end{array}$} & \multicolumn{2}{|c|}{$\begin{array}{l}\text { Regression Produc- } \\
\text { tions-Attractions }\end{array}$} \\
\hline & $\begin{array}{c}\text { Vehicle } \\
\text { Hours } \\
\end{array}$ & $\begin{array}{l}\text { Average } \\
\text { Trip } \\
\text { Length }\end{array}$ & $\begin{array}{l}\text { Vehicle } \\
\text { Hours } \\
\end{array}$ & $\begin{array}{l}\text { Average } \\
\text { Trip } \\
\text { Length }\end{array}$ & $\begin{array}{c}\text { Vehicle } \\
\text { Hours } \\
\end{array}$ & $\begin{array}{l}\text { Average } \\
\text { Trip } \\
\text { Length }\end{array}$ \\
\hline Home-Work & 1831 & 6.06 & 1823 & 6.03 & 1970 & 6.01 \\
\hline Home-Other & 2584 & 4.91 & 2610 & 4.95 & 2845 & 5.22 \\
\hline Non-Home & 1597 & 4.48 & 1657 & 4.64 & 1823 & 4.60 \\
\hline
\end{tabular}

* Average Trip Length in Minutes/Trip

TABLE 31

COMPARISON OF VEHICLE HOURS OF TRAVEL AND AVERAGE TRIP LENGTH FROM O-D AND MODEL DATA USING TRAVEL TIME FACTORS FROM THE 14 SELECTED ZONES REDUCED SAMPIE O-D DATA

\begin{tabular}{|c|c|c|c|c|c|c|}
\hline \multirow[b]{2}{*}{ Purpose } & \multicolumn{2}{|c|}{$\begin{array}{c}\text { Complete } 0-D \\
\text { Survey Data }\end{array}$} & \multicolumn{2}{|c|}{$\begin{array}{l}\text { O-D Productions- } \\
\text { Attractions } \\
\end{array}$} & \multicolumn{2}{|c|}{$\begin{array}{l}\text { Regression Produc- } \\
\text { tions-Attractions }\end{array}$} \\
\hline & $\begin{array}{l}\text { Vehicle } \\
\text { Hours }\end{array}$ & $\begin{array}{l}\text { Average } \\
\text { Trip } \\
\text { Length* } \\
\end{array}$ & $\begin{array}{l}\text { Vehicle } \\
\text { Hours } \\
\end{array}$ & $\begin{array}{l}\text { Average } \\
\text { Trip } \\
\text { Length } \\
\end{array}$ & $\begin{array}{l}\text { Vehicle } \\
\text { Hours }\end{array}$ & $\begin{array}{l}\text { Average } \\
\text { Trip } \\
\text { Length } \\
\end{array}$ \\
\hline Home-Work & 1831 & 6.06 & 1842 & 6.09 & 2028 & 6.18 \\
\hline Home-Other & 2584 & 4.91 & 2627 & 4.98 & 2855 & 5.24 \\
\hline Non-Home & 1597 & 4.48 & 1657 & 4.64 & 1823 & 4.60 \\
\hline
\end{tabular}

* Average Trip Length in Minutes/Trip 
TABLE 32

COMPARISON OF VEHICLE MILE' OF TRAVLL AND AVERAGE TRIP LENGTI FROM O-D AND MODLL DATA USING TRAVEL

TIE FACTORS FROM THE FULL SAMPLE O-D DATA

\begin{tabular}{|c|c|c|c|c|c|c|}
\hline \multirow[b]{3}{*}{$\begin{array}{l}\text { Trip } \\
\text { Purpose }\end{array}$} & \multirow{2}{*}{\multicolumn{2}{|c|}{$\begin{array}{l}\text { Complete O-D } \\
\text { Survey Data }\end{array}$}} & \\
\hline & & & \multicolumn{2}{|c|}{$\begin{array}{l}\text { O-D Productions } \\
\text {-Attractions }\end{array}$} & \multicolumn{2}{|c|}{$\begin{array}{l}\text { Regression Produc } \\
\text {-tions-Attractions }\end{array}$} \\
\hline & $\begin{array}{l}\text { Vehicle } \\
\text { Miles }\end{array}$ & $\begin{array}{l}\text { Average } \\
\text { Trip } \\
\text { Length* }\end{array}$ & $\begin{array}{l}\text { Vehicle } \\
\text { Miles }\end{array}$ & $\begin{array}{l}\text { Average } \\
\text { Trip } \\
\text { Length* }\end{array}$ & $\begin{array}{l}\text { Vehicle } \\
\text { Miles }\end{array}$ & $\begin{array}{c}\text { Averagc } \\
\text { Trip } \\
\text { Length* }\end{array}$ \\
\hline Home-Work & 35331.6 & 1.946 & 35325.6 & 1.947 & 38327.3 & 1.948 \\
\hline Home-Other & 48248.2 & 1.527 & 49193.3 & 1.552 & 54894.9 & 1.680 \\
\hline Non-Home & 30755.6 & 1.438 & 30630.7 & 1.431 & 33731.9 & 1.419 \\
\hline
\end{tabular}

* Average Trip Length in Mi./Trip

TABLE 33

COMPARISON OF VEHICLE MILES OF TRAVEL AIND AVERAGE TRIP LENGTH FROM O-D AND MODEL DATA USING TRAVEL TIME FACTOR' FROM THE 14 SELECTED ZONES REDUCED SAMPLE O-D DATA

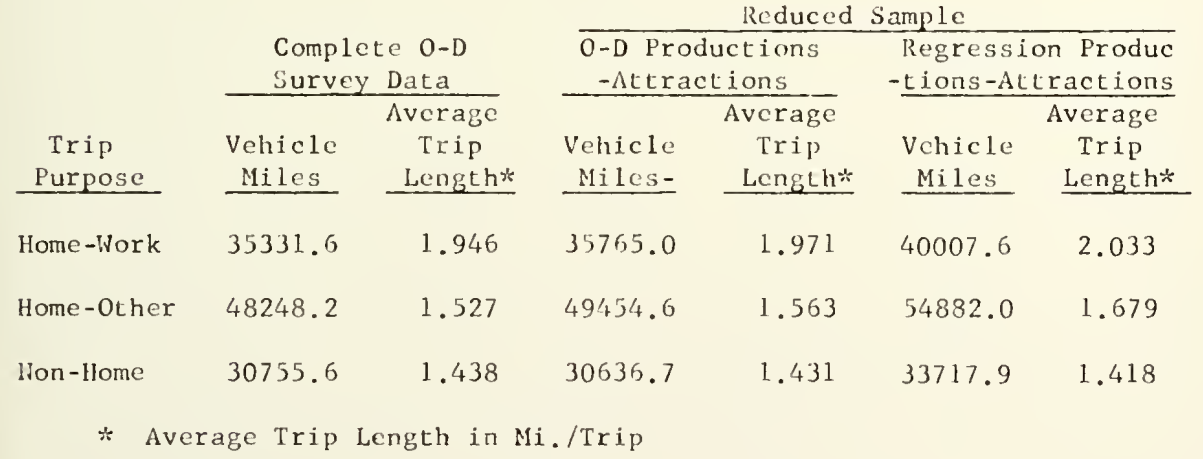


vehicle miles of travel was taken as the product of the zone interchange and the " $L$ " distance between the zone centroids in question with the summation being made over all zones. The average trip length in miles was taken as the total vehicle miles of travel divided by the total number of trips.

\section{Comparison of District to District Movements}

A comparison also was made of the district to district movements given by both the model and $\mathrm{O}-\mathrm{D}$ data. The comparison was originally made using zone to zone movements but the small numbers of trips gave results having little stability. Table 19 indicates the zones that were contained in the various districts. The RMS errors for the various volume groups and trip purposes, as shown in Tables 34 through 43 , indicate that two-thirds of the time the difference between district interchanges, as given by the model and O-D data, is expected to be equal to, or less than, the value of the RMS error.

District-to-district trip interchanges can be used in determining interchange volumes between the CBD and various "corridors". This can provide a check on the geographical bias of the model. However, in this analysis, it was felt that the "screenline" checks gave a dependable test for bias. 
TABLE 34

ANALYSIS OF DISTRICT TO DISTRICT $\angle 1$ MOVEMENTS

HOME - WORK TRIPS, FULL SAMPLE, COMPLETE O-D PRODUCTIONSATTRACTIONS, TRAVEL TIME FACTORS FROM REDUCED SAMPLE O-D DATA

\begin{tabular}{|c|c|c|c|c|c|c|c|}
\hline $\begin{array}{l}\text { Volume } \\
\text { Group }\end{array}$ & Freq $/ 2$ & $\frac{\text { Tota }}{0-D}$ & $\begin{array}{l}\text { Trips } \\
\text { Model }\end{array}$ & $\begin{array}{c}\text { Mean } \\
\text { D1fference }\end{array}$ & $\begin{array}{c}\text { Standard } \\
\text { Deviation } \\
\end{array}$ & $\begin{array}{c}\text { RMS } \\
\text { Error }\end{array}$ & $\begin{array}{l}\text { D RMS } \\
\text { Error }\end{array}$ \\
\hline $0-99$ & 106 & 4,803 & 5,718 & -8 & 27 & 28 & 63 \\
\hline $100-199$ & 26 & 3,644 & 3,380 & 10 & 48 & 49 & 35 \\
\hline $200-299$ & 5 & 1,236 & 1,053 & 36 & 90 & 98 & 39 \\
\hline $300-399$ & 6 & 2,122 & 2,170 & -8 & 51 & 52 & 14 \\
\hline $400-499$ & 4 & 1,828 & 1,779 & 12 & 54 & 56 & 12 \\
\hline $500-599$ & 2 & 1,112 & 1,087 & 12 & 79 & 80 & 14 \\
\hline $600-699$ & 1 & 607 & 525 & 82 & --- & 81 & 13 \\
\hline $700-799$ & --- & -- & --- & -- & -- & -- & -- \\
\hline $800-899$ & 1 & 844 & 891 & -47 & --- & 46 & 5 \\
\hline $900-999$ & --- & --- & -- & --- & --- & -- & -- \\
\hline $1000-1499$ & -- & -- & --- & --- & -- & -- & --- \\
\hline $1500-1999$ & 1 & 1,691 & 1,355 & 336 & --- & 335 & 19 \\
\hline $2000-2999$ & -- & --- & --- & --- & --- & --- & --- \\
\hline $3000-3999$ & --- & --- & --- & --- & --- & -.- & - \\
\hline $4000-4999$ & --- & -- & -- & --- & --- & --- & -- \\
\hline $5000-5999$ & --- & --- & --- & -- & -- & --- & -- \\
\hline $6000-6999$ & -- & -- & -- & -- & -- & -- & --- \\
\hline $7000-7999$ & --- & --- & --- & --- & --- & --- & -- \\
\hline $8000-8999$ & -- & --- & $-\infty$ & --- & --- & --- & -- \\
\hline $9000-9999$ & --- & --- & -- & -- & --- & --- & --- \\
\hline $10000-999999$ & -- & -- & -- & -- & --- & -- & --- \\
\hline TOTAL & & 17,887 & 17,958 & & & & \\
\hline
\end{tabular}

11 See Table 19 for zones making up each district.

12 Number of district to district movements within the volume group. 
TABLE 35

ANALYSIS OF DISTRICT TO DISTRICT $\angle 1$ MOVEMENTS

HOME - OTHER TRIPS, FULL SAM] E, COMPLETE O-D PRODUCTIONSATTRACTIONS, TRAVEL TIME FACTORS FROM REDUCED SAMPLE O-D DATA

\begin{tabular}{|c|c|c|c|c|c|c|c|}
\hline $\begin{array}{l}\text { Volume } \\
\text { Group }\end{array}$ & Freq $/ 2$ & Tota & Trips & $\begin{array}{c}\text { Mean } \\
\text { Difference }\end{array}$ & $\begin{array}{c}\text { Standard } \\
\text { Deviation }\end{array}$ & $\begin{array}{c}\text { RMS } \\
\text { Error }\end{array}$ & $\begin{array}{l}\text { क RMS } \\
\text { Error }\end{array}$ \\
\hline $0-99$ & 79 & 3,483 & 4,227 & -9 & 29 & 30 & 69 \\
\hline $100-199$ & 31 & 4,303 & 4,796 & -15 & 54 & 57 & 41 \\
\hline $200-299$ & 10 & 2,455 & 2,653 & -19 & 122 & 123 & 50 \\
\hline $300-399$ & 7 & 2,340 & 2,296 & 6 & 101 & 101 & 30 \\
\hline $400-499$ & 7 & 3,191 & 2,580 & 87 & 135 & 161 & 35 \\
\hline $500-599$ & 6 & 3,312 & 3,456 & -24 & 95 & 98 & 17 \\
\hline $600-699$ & 5 & 3,201 & 3,329 & -25 & 139 & 141 & 22 \\
\hline $700-799$ & 2 & 1,459 & 1,628 & -84 & 245 & 259 & 35 \\
\hline $800-899$ & 2 & 1,671 & 1,019 & 326 & 100 & 341 & 40 \\
\hline $900-999$ & 2 & 1,913 & 2,234 & -160 & 74 & 176 & 18 \\
\hline $1000-1499$ & --- & -- & --- & --- & --- & -- & --- \\
\hline $1500-1999$ & 1 & 1,669 & 1,779 & -110 & --- & 109 & 6 \\
\hline $2000-2999$ & 1 & 2,150 & 1,457 & 693 & -- & 692 & 32 \\
\hline $3000-3999$ & --- & -- & --- & --- & $---\cdot$ & --- & --- \\
\hline $4000-4999$ & --- & --- & --- & --- & -- & --- & --- \\
\hline $5000-5999$ & -- & --- & --- & --- & --- & --- & -- \\
\hline $6000-6999$ & -- & --- & --- & --- & --- & --- & --- \\
\hline $7000-7999$ & --- & --- & --- & $\because--$ & --- & --- & -- \\
\hline $8000-8999$ & --- & --- & --- & --- & --- & --- & --- \\
\hline . 9000-9999 & $-\infty$ & -- & --- & -- & --- & --- & $-\cdots$ \\
\hline $10000-999999$ & -- & --- & -- & --- & --- & --- & --- \\
\hline TOTAL & & 31,147 & 31,454 & & & & \\
\hline
\end{tabular}

1 See Table 19 for zones making up each district.

I2 Number of district to district movements within the volume group. 
TABLE 36

ANALYSIS OF DISTRICT TO DISTRICT $\angle 1$ MOVEMENTS

NON - HOME TRIPS, FULL SAMPLE, COMPLETE O-D PRODUCTIONSATTRACTIONS, TRAVEL TIME FACTORS FROM REDUCED SAMPLE O-D DATA

\begin{tabular}{|c|c|c|c|c|c|c|c|}
\hline $\begin{array}{l}\text { Volume } \\
\text { Group }\end{array}$ & Freq $\angle 2$ & $\begin{array}{l}\text { Tota } \\
0-D \\
\end{array}$ & Trips & \begin{tabular}{|c|} 
Mean \\
Difference \\
\end{tabular} & $\begin{array}{l}\text { Standard } \\
\text { Deviation }\end{array}$ & \begin{tabular}{|c|} 
RMS \\
Error \\
\end{tabular} & $\begin{array}{l}\text { क RMS } \\
\text { Error }\end{array}$ \\
\hline $0-99$ & 112 & 4,185 & 4,504 & -2 & 21 & 22 & 59 \\
\hline $100-199$ & 16 & 2,080 & 1,863 & 13 & 27 & 30 & 23 \\
\hline $200-299$ & 11 & 2,702 & 2,523 & 16 & 66 & 68 & 27 \\
\hline $300-399$ & 3 & 1,031 & 955 & 25 & 49 & 55 & 16 \\
\hline $400-499$ & 2 & 923 & 793 & 65 & 6 & 65 & 14 \\
\hline $500-599$ & 3 & 1,747 & 1,868 & -40 & 63 & 75 & 12 \\
\hline $600-699$ & -- & --- & --- & -- & -- & --- & --- \\
\hline $700-799$ & 1 & 783 & 720 & 63 & --- & 62 & 8 \\
\hline $800-899$ & - & --- & --- & --- & -- & $-\infty$ & $\rightarrow$ \\
\hline $900-999$ & 2 & 1,963 & 2,053 & -45 & 3 & 45 & 4 \\
\hline $1000-1499$ & 2 & 2,427 & 2,381 & 23 & 47 & 53 & 4 \\
\hline $1500-1999$ & -- & -- & -- & -- & -- & --- & --- \\
\hline $2000-2999$ & -- & --- & --- & --- & --- & --- & --- \\
\hline $3000-3999$ & 1 & 3,335 & 3,522 & -187 & -- & 186 & 5 \\
\hline $4000-4999$ & -- & --- & -- & -- & --- & --- & --- \\
\hline $5000-5999$ & -- & --- & --- & -- & --- & --- & $-\infty$ \\
\hline $6000-6999$ & -- & -- & --- & -- & --- & -- & --- \\
\hline $7000-7999$ & -- & --- & --- & --- & --- & --- & --- \\
\hline $8000-8999$ & -- & --- & --- & -- & -- & -- & --- \\
\hline $9000-9999$ & -- & --- & --- & $-\cdots$ & -- & --- & --- \\
\hline $10000-999999$ & -- & --- & -- & --- & --- & --- & -- \\
\hline TOTAL & & 21,176 & 21,182 & & & & \\
\hline
\end{tabular}

11 See Table 19 for zones making up each district.

I2 Number of district to district movements within the volume group. 
TABLE 37

ANALYSIS OF DISTRICT TO DISTRICT $\angle 1$ MOVEMENTS

ALL TRIPS, FULL SAMPLE, COMPLETE O-D PRODUCTIONS-

ATTRACTIONS, TRAVEL TIME FACTORS FROM REDUCED SAMPLE O-D DATA

\begin{tabular}{|c|c|c|c|c|c|c|c|}
\hline $\begin{array}{l}\text { Volume } \\
\text { Group }\end{array}$ & Freq 2 & $\begin{array}{l}\text { Tota } \\
0-D\end{array}$ & $\begin{array}{l}\text { Trips } \\
\text { Model }\end{array}$ & $\begin{array}{c}\text { Mean } \\
\text { Difference } \\
\end{array}$ & $\begin{array}{c}\text { Standard } \\
\text { Devtation }\end{array}$ & \begin{tabular}{|c|} 
RMS \\
Error \\
\end{tabular} & $\begin{array}{l}\text { \% RMS } \\
\text { Error }\end{array}$ \\
\hline $0-99$ & 33 & 1,858 & 1,929 & -2 & 39 & 39 & 69 \\
\hline $100-199$ & 32 & 4,648 & 5,066 & -13 & 60 & 61 & 42 \\
\hline $200-299$ & 32 & 7,875 & 8,396 & -16 & 98 & 99 & 40 \\
\hline $300-399$ & 14 & 4,891 & 4,970 & -5 & 93 & 94 & 26 \\
\hline $400-499$ & 8 & 3,476 & 3,627 & -18 & 66 & 69 & 15 \\
\hline $500-599$ & 2 & 1,089 & 480 & 304 & 83 & 315 & 57 \\
\hline $600-699$ & 4 & 2,576 & 2,484 & 23 & 88 & 91 & 14 \\
\hline $700-799$ & 4 & 2,943 & 2,996 & -13 & 182 & 182 & 24 \\
\hline $800-899$ & 2 & 1,641 & 1,750 & -54 & 65 & 85 & 10 \\
\hline $900-999$ & 2 & 1,896 & 1,681 & 107 & 92 & 141 & 14 \\
\hline $1000-1499$ & 10 & 12,750 & 12,482 & 26 & 315 & 316 & 24 \\
\hline $1500-1999$ & 4 & 6,753 & 6,400 & 88 & 228 & 245 & 14 \\
\hline $2000-2999$ & 4 & 9,581 & 10,393 & -203 & 168 & 263 & 11 \\
\hline $3000-3999$ & 1 & 3,549 & 3,853 & -304 & --- & 303 & 8 \\
\hline $4000-4999$ & --- & --- & --- & --- & --- & -- & --- \\
\hline $5000-5999$ & 1 & 5,199 & 4,087 & 1,112 & -- & 1,112 & 21 \\
\hline $6000-6999$ & -- & --- & --- & --- & --- & --- & -- \\
\hline $7000-7999$ & -- & --- & --- & --- & --- & --- & --- \\
\hline $8000-8999$ & --- & --- & -- & --- & --- & $\rightarrow$ & --- \\
\hline $9000-9999$ & --- & . --- & --- & --- & --- & --- & --- \\
\hline $10000-999999$ & --- & --- & $--\dot{0}$ & --- & --- & -- & --- \\
\hline TOTAL & & 70,725 & 70,594 & & & & \\
\hline
\end{tabular}

41 See Table 19 for zones making up each district.

12 Number of district to district movements within the volume group. 
TABLE 38

ANALYSIS OF DISTRICT TO DISTRICT $\angle 1$ MOVEMENTS

HOME - WORK TRIPS, FULL SAMPLE, REGRESSION PRODUCTIONS-

ATTRACTIONS, TRAVEL TIME FACTORS FROM REDUCED SAMPLE O-D DATA

\begin{tabular}{|c|c|c|c|c|c|c|c|}
\hline $\begin{array}{l}\text { Volume } \\
\text { Group }\end{array}$ & Freq $/ 2$ & Tota & $\begin{array}{l}\text { Trips } \\
\text { Model } \\
\end{array}$ & $\begin{array}{c}\text { Mean } \\
\text { Difference }\end{array}$ & $\begin{array}{c}\text { Standard } \\
\text { Deviation }\end{array}$ & $\begin{array}{c}\text { RMS } \\
\text { Error }\end{array}$ & $\begin{array}{l}\text { क RMS } \\
\text { Error }\end{array}$ \\
\hline $0-99$ & 106 & 4,803 & 6,813 & -18 & 31 & 36 & 81 \\
\hline $100-199$ & 26 & 3,644 & 3,655 & --- & 56 & 56 & 40 \\
\hline $200-299$ & 5 & 1,236 & 1,027 & 41 & 57 & 70 & 28. \\
\hline $300-399$ & 6 & 2,122 & 2,579 & -76 & 147 & 166 & 47 \\
\hline $400-499$ & 4 & 1,828 & 1,793 & 8 & 39 & 40 & 8 \\
\hline $500-599$ & 2 & 1,112 & 1,161 & -24 & 108 & 111 & 20 \\
\hline $600-699$ & 1 & 607 & 455 & 152 & --- & 151 & 25 \\
\hline $700-799$ & --- & --- & --- & --- & --- & -- & --- \\
\hline $800-899$ & 1 & 844 & 996 & -152 & --- & 151 & 18 \\
\hline $900-999$ & --- & --- & --- & --- & --- & --- & --- \\
\hline $1000-1499$ & --- & --- & --- & --- & --- & --- & -- \\
\hline $1500-1999$ & 1 & 1,691 & 1,089 & 602 & --- & 601 & 35 \\
\hline $2000-2999$ & --- & --- & --- & --- & -- & --- & --- \\
\hline $3000-3999$ & --- & --- & --- & --- & $--\cdot$ & --- & --- \\
\hline 4000-4999 & --- & --- & --- & --- & --- & --- & --- \\
\hline $5000-5999$ & -- & --- & --- & -- & --- & --- & -- \\
\hline $6000-6999$ & --- & --- & --- & --- & -- & --- & --- \\
\hline $7000-7999$ & --- & --- & --- &.-- & --- & -- & --- \\
\hline $8000-8999$ & --- & --- & --- & -- & --- & -- & -- \\
\hline $9000-9999$ & --- & --- & --- & -- & --- & --- & --- \\
\hline $10000-999999$ & --- & --- & -- & --- & -- & --- & $\cdots$ \\
\hline TOTAL & & 17,887 & 19,568 & & & & \\
\hline
\end{tabular}

11 See Table 19 for zones making up each district.

12 Number of district to district movements within the volume group. 
TABLE 39

ANALYSIS OF DISTRICT TO DISTRICT $\angle 1$ MOVEMENTS

HOME - OTHER TRIPS, FULL SAMPLE, REGRESSION PRODUCTIONSATTRACTIONS, TRAVEL TIME FACTORS FROM REDUCED SAMPIE O-D DATA

\begin{tabular}{|c|c|c|c|c|c|c|c|}
\hline $\begin{array}{l}\text { Volume } \\
\text { Group }\end{array}$ & Freq $\angle 2$ & $\begin{array}{l}\text { Total } \\
O-D \\
\end{array}$ & $\frac{\text { Trips }}{\text { Model }}$ & $\begin{array}{c}\text { Mean } \\
\text { Difference }\end{array}$ & $\begin{array}{c}\text { Standard } \\
\text { Deviation }\end{array}$ & $\begin{array}{c}\text { RMS } \\
\text { Error }\end{array}$ & $\begin{array}{l}\text { \% RMS } \\
\text { Error }\end{array}$ \\
\hline $0-99$ & 79 & 3,483 & 4,959 & -18 & 41 & 45 & 102 \\
\hline $100-199$ & 31 & 4,303 & 5,154 & -27 & 65 & 70 & .51 \\
\hline $200-299$ & 10 & 2,455 & 2,623 & -16 & 100 & 101 & 41 \\
\hline $300-399$ & 7 & 2,340 & 3,123 & -111 & 104 & 152 & 45. \\
\hline $400-499$ & 7 & 3,191 & 2,683 & 72 & 186 & 199 & 43 \\
\hline $500-599$ & 6 & 3,312 & 3,226 & 14 & 32 & 35 & 6 \\
\hline $600-699$ & 5 & 3,201 & 3,356 & -31 & 60 & 67 & 10 \\
\hline $700-799$ & 2 & 1,459 & 1,602 & -71 & 177 & 191 & 26 \\
\hline $800-899$ & 2 & 1,691 & 946 & 362 & 60 & 367 & 43 \\
\hline $900-999$ & 2 & 1,913 & 2,167 & -127 & 150 & 197 & 20 \\
\hline $1000-1499$ & --- & --- & --- & --- & --- & -- & -- \\
\hline $1500-1999$ & 1 & 1,669 & 1,420 & 249 & --- & 248 & 14 \\
\hline $2000-2999$ & 1 & 2,150 & 1,311 & 839 & --- & 838 & 39 \\
\hline $3000-3999$ & --- & --- & -- & --- & --- & --- & --- \\
\hline $4000-4999$ & -- & -- & --- & --- & --- & -- & --- \\
\hline $5000-5999$ & --- & -- & -- & --- & -- & -- & --- \\
\hline $6000-6999$ & -- & --- & -- & --- & --- & --- & --- \\
\hline $7000-7999$ & --- & --- & -- & $\because--$ & --- & -- & --- \\
\hline $8000-8999$ & $--\infty$ & --- & -- & --- & --- & $-\infty$ & --- \\
\hline $9000-9999$ & --- & --- & --- & --- & --- & --- & --- \\
\hline 10000-999999 & -- & --- & $--\dot{-}$ & --- & --- & --- & -- \\
\hline TOTAL & & 31,107 & 32,570 & & & & \\
\hline
\end{tabular}

11 See Table 19 for zones making up each district.

$\llbracket 2$ Number of district to district movements within the volume group. 
TABLE 40

ANALYSIS OF DISTRICT TO DISTRICT $\angle 1$ MOVEMENTS

NON - HOME TRIPS, FULL SAMPLE, REGRESSION PRODUCTIONSATTRACTIONS, TRAVEL TIME FACTORS FROM REDUCED SAMPLE O-D DATA

\begin{tabular}{|c|c|c|c|c|c|c|c|}
\hline $\begin{array}{l}\text { Volume } \\
\text { Group }\end{array}$ & Freq $/ 2$ & $\begin{array}{l}\text { Total } \\
0-D\end{array}$ & $\begin{array}{l}\text { Trips } \\
\text { Model } \\
\end{array}$ & $\begin{array}{c}\text { Mean } \\
\text { Difference }\end{array}$ & $\begin{array}{l}\text { Standard } \\
\text { Deviation }\end{array}$ & \begin{tabular}{|c|} 
RMS \\
Error \\
\end{tabular} & $\begin{array}{l}\text { क RMS } \\
\text { Error }\end{array}$ \\
\hline $0-99$ & 111 & 4,185 & 4,831 & -5 & 29 & 30 & 80 \\
\hline $100-199$ & 16 & 2,080 & 2,072 & --- & 54 & 54 & 41 \\
\hline $200-299$ & 11 & 2,702 & 2,463 & 21 & 113 & 115 & 47 \\
\hline $300-399$ & 3 & 1,031 & 1,049 & -6 & 43 & 43 & 12 \\
\hline $400-499$ & 2 & 923 & 840 & 41 & 33 & 53 & 11 \\
\hline $500-599$ & 3 & 1,747 & 2,019 & -90 & 196 & 216 & 37 \\
\hline $600-699$ & -- & --- & --- & -- & -- & $\therefore-$ & --- \\
\hline $700-799$ & 1 & 783 & 977 & -194 & -- & 193 & 24 \\
\hline $800-899$ & --- & --- & --- & --- & -- & --- & --- \\
\hline $900-999$ & 2 & 1,963 & 2,203 & -120 & 157 & 198 & 20 \\
\hline $1000-1499$ & 2 & 2,427 & 2,721 & -147 & 97 & 176 & 14 \\
\hline $1500-1999$ & -- & -- & --- & --- & --- & --- & $\ldots$ \\
\hline $2000-2999$ & -- & --- & --- & --- & --- & --- & --- \\
\hline $3000-3999$ & 1 & 3,335 & 4,523 & $-1,188$ & --- & 1,187 & 35. \\
\hline $4000-4999$ & -- & -- & --- & --- & $\ldots$ & --- & --- \\
\hline $5000-5999$ & --- & -- & --- & --- & -- & --- & -- \\
\hline 6000-6999 & --- & -- & --- & --- & --- & -- & -- \\
\hline $7000-7999$ & --- & --- & --- & --- & --- & --- & --- \\
\hline $8000-8999$ & --- & -- & --- & --- & --- & -- & --- \\
\hline $9000-9999$ & --- & --- & --- & --- & --- & -- & -- \\
\hline $10000-999999$ & --- & --- & $--\dot{-}$ & --- & -- & --- & -- \\
\hline TOTAL & & 21,176 & 23,698 & & & & \\
\hline
\end{tabular}

1 See Table 19 for zonés making up each district.

12 Number of district to district movements within the volume group. 
TABLE 41

ANALYSIS OF DISTRICT TO DISTRICT $\angle 1$ MOVEMENTS

ALL TRIPS, FULL SAMPLE, REGRESSION PRODUCTIONS-

ATTRACTIONS, TRAVEL TIME FACTORS FROM REDUCED SAMPLE O-D DATA

\begin{tabular}{|c|c|c|c|c|c|c|c|}
\hline $\begin{array}{l}\text { Volume } \\
\text { Group }\end{array}$ & Freq $/ 2$ & $\frac{\text { Tota }}{0-D}$ & \begin{tabular}{|l|} 
Trips \\
Model
\end{tabular} & $\begin{array}{c}\text { Mean } \\
\text { Difference }\end{array}$ & $\begin{array}{c}\text { Standard } \\
\text { Deviation }\end{array}$ & $\begin{array}{l}\text { RMS } \\
\text { Error }\end{array}$ & $\begin{array}{l}\text { क RMS } \\
\text { Error }\end{array}$ \\
\hline $0-99$ & 33 & 1,858 & 2,491 & 19 & 49 & 52 & 93 \\
\hline $100-199$ & 32 & 4,648 & 6,219 & -49 & 76 & 90 & 62 \\
\hline $200-299$ & 32 & 7,875 & 8,831 & -29 & 89 & 93 & 38 \\
\hline $300-399$ & 14 & 4, 891 & 6,075 & -84 & 132 & 157 & 44 \\
\hline $400-499$ & 8 & 3,476 & 4,024 & -68 & 109 & 129 & 29 \\
\hline $500-599$ & 2 & 1,089 & 582 & 253 & 158 & 298 & 54 \\
\hline $600-699$ & 4 & 2,576 & 2,883 & -76 & 234 & 247 & 38 \\
\hline $700-799$ & 4 & 2,943 & 2,608 & 83 & 143 & 165 & 22 \\
\hline $800-899$ & 2 & 1,641 & 1,800 & -79 & 162 & 180 & 22 \\
\hline $900-999$ & 2 & 1,896 & 1,735 & 80 & 77 & 111 & 11 \\
\hline $1000-1499$ & 10 & 12,750 & 12,558 & 19 & 328 & 329 & 25 \\
\hline $1500-1999$ & 4 & 6,753 & 6,659 & 23 & 289 & 290 & 17 \\
\hline $2000-2999$ & 4 & 9,581 & 10,739 & -289 & 411 & 503 & 21 \\
\hline $3000-3999$ & 1 & 3,549 & 4,837 & $-1,288$ & --- & 1,287 & 36. \\
\hline $4000-4999$ & -- & --- & --- & --- & --- & --- & --- \\
\hline $5000-5999$ & 1 & 5,199 & 3,795 & 1,404 & --- & 1,403 & 27 \\
\hline $6000-6999$ & --- & --- & --- & --- & --- & --- & --- \\
\hline $7000-7999$ & --- & --- & --- &.-- & --- & --- & --- \\
\hline $8000-8999$ & -- & --- & --- & --- & --- & --- & --- \\
\hline 9000-9999 & -- & . -- & -- & --- & --- & --- & --- \\
\hline $10000-999999$ & -- & --- & --- & --- & --- & --- & --- \\
\hline TOTAL & & 70,725 & 75,836 & & & & \\
\hline
\end{tabular}

11 See Table 19 for zones making up each district.

12 Number of district to district movements within the volume group. 
TABLE 42

ANALYSIS OF DISTRICT TO DISTRICT $\angle 1$ MOVEMENTS

ALL TRIPS, FULL SAMPLE, COMPLETE O-D PRODUCTIONSATTRACTIONS, TRAVEL TIME FACTORS FROM FULL SAMPLE O-D DATA

\begin{tabular}{|c|c|c|c|c|c|c|c|}
\hline $\begin{array}{l}\text { Volume } \\
\text { Group }\end{array}$ & Freq $\angle 2$ & $\begin{array}{l}\text { Total } \\
0-D \\
\end{array}$ & $\frac{\text { Trips }}{\text { Model }}$ & $\begin{array}{c}\text { Mean } \\
\text { Difference }\end{array}$ & $\begin{array}{c}\text { Standard } \\
\text { Deviation }\end{array}$ & \begin{tabular}{|c|} 
RMS \\
Error \\
\end{tabular} & $\begin{array}{l}\text { D RMS } \\
\text { Error }\end{array}$ \\
\hline $0-99$ & 33 & 1,858 & 1,965 & -3 & 39 & 39 & 70 \\
\hline $100-199$ & 32 & 4,648 & 5,041 & -12 & 60 & 61 & 42 \\
\hline $200-299$ & ' 32 & 7,875 & 8,389 & -16 & 99 & 100 & 40 \\
\hline $300-399$ & 14 & 4,891 & 4,915 . & -1 & 90 & 90 & 25 \\
\hline $400-499$ & 8 & 3,476 & 3,638 & -20 & 78 & 81 & 18 \\
\hline $500-599$ & 2 & 1,089 & 506 & 291 & 85 & 303 & 55 \\
\hline $600-699$ & 4 & 2,576 & 2,517 & 14 & 91 & 92 & 14 \\
\hline $700-799$ & 4 & 2,943 & 3,001 & -17 & 196 & 197 & 26 \\
\hline $800-899$ & 2 & 1,641 & 1,757 & -58 & 29 & 65 & 7 \\
\hline $900-999$ & 2 & 1,896 & 1,662 & 117 & 85 & 145 & 15 \\
\hline $1000-1499$ & 10 & 12,750 & 12,433 & 31 & 294 & 296 & 23 \\
\hline $1500-1999$ & 4 & 6,753 & 6,399 & 88 & 251 & 256 & 15 \\
\hline $2000-2999$ & 4 & 9,581 & 10,498 & -229 & 159 & 279 & 11 \\
\hline $3000-3999$ & 1 & 3,549 & 3,868 & -319 & --- & 318 & 8 \\
\hline $4000-4999$ & -- & -- & --- & --- & --- & --- & --- \\
\hline $5000-5999$ & 1 & 5,199 & 4,018 & 1,181 & -- & 1,180 & 22 \\
\hline $6000-6999$ & -- & --- & -- & --- & --- & --- & --- \\
\hline $7000-7999$ & --- & -- & --- & $\ldots$ & --- & --- & --- \\
\hline $8000-8999$ & --- & --- & --- & --- & -- & --- & --- \\
\hline $9000-9999$ & --- & -- & --- & --- & ,--i & --- & -- \\
\hline $10000-999999$ & --- & --- & $-\dot{-}$ & --- & --- & --- & --- \\
\hline TOTAL & & 70,725 & 70,607 & & & & \\
\hline
\end{tabular}

11 See Table 19 for zones making up each district.

12 Number of district to district movements within the volume group. 
TABLE 43

ANALYSIS OF DISTRICT TO DISTRICT $\angle 1$ MOVEMENTS

ALL TRIPS, FULL SAMPLE, REGRESSION PRODUCTIONS-

ATTRACTIONS, TRAVEL TIME FACTORS FROM FULL SAMPLE O-D DATA

\begin{tabular}{|c|c|c|c|c|c|c|c|}
\hline $\begin{array}{l}\text { Volume } \\
\text { Group }\end{array}$ & Freq $\angle 2$ & $\begin{array}{l}\text { Tota } \\
\text { O-D }\end{array}$ & $\frac{\text { Tr1ps }}{\text { Model }}$ & $\begin{array}{c}\text { Mean } \\
\text { Difference }\end{array}$ & $\begin{array}{c}\text { Standard } \\
\text { Deviation }\end{array}$ & $\begin{array}{c}\text { RMS } \\
\text { Error }\end{array}$ & $\begin{array}{l}\text { क RMS } \\
\text { Error }\end{array}$ \\
\hline $0-99$ & 33 & 1,858 & 2,554 & -21 & 48 & 52 & 93 \\
\hline $100-199$ & 32 & 4,648 & 5,907 & -39 & 83 & 92 & 63 \\
\hline $200-299$ & 32 & 7,875 & 8,752 & -27 & 89 & - 92 & 37 \\
\hline $300-399$ & 14 & 4,891 & 6,034 & -81 & 137 & 160 & 45 \\
\hline $400-499$ & 8 & 3,476 & 3,923 & -55 & 116 & 129 & 29 \\
\hline $500-599$ & 2 & 1,089 & 611 & 239 & 164 & 290 & 53 \\
\hline $600-699$ & 4 & 2,576 & 2,970 & -98 & 250 & 269 & 41 \\
\hline $700-799$ & 4 & 2,943 & 2,653 & 72 & 164 & 180 & 24 \\
\hline $800-899$ & 2 & 1,641 & 1,815 & -87 & 118 & 147 & 17 \\
\hline $900-999$ & 2 & 1,896 & 1,725 & 85 & 78 & 116 & 12 \\
\hline $1000-1499$ & 10 & 12,750 & 12,603 & 14 & 309 & 309 & 24 \\
\hline $1500-1999$ & 4 & 6,753 & 6,714 & 9 & 303 & 32 & 18 \\
\hline $2000-2999$ & 4 & 9,581 & 10,923 & -335 & 374 & 502 & 20 \\
\hline $3000-3999$ & 1 & 3,549 & 4,846 & $-1,297$ & -- & 1,296 & 36 \\
\hline $4000-4999$ & --- & --- & -- & $\ldots$ & -- & --- & -- \\
\hline $5000-5999$ & 1 & 5,199 & 3,780 & 1,419 & -- & 1,418 & 27 \\
\hline $6000-6999$ & --- & $-\cdots$ & -- & $-\infty$ & --- & -- & $-\cdots$ \\
\hline $7000-7999$ & -- & $-\quad--$ & -- & $\because-$ & --- & $\cdots$ & --- \\
\hline $8000-8999$ & --- & --- & --- & -- & -- & -- & --- \\
\hline $9000-9999$ & -- & --- & $\ldots$ & --- & $-\cdots$ & --- & $\cdots$ \\
\hline 10000-999999 & -- & --- & $\ddot{-}$ & --- & --- & -- & -- \\
\hline TOTAL & & 70,725 & 75,810 & & & & \\
\hline
\end{tabular}

11 See Table 19 for zones making up each district.

$\angle 2$ Number of district to district movements within the volume group. 


\section{CONCLUSIONS}

It is concluded that:

1. Current zonal trip productions and attractions were adequately estimated from mathematical models developed from a small sample of home interviews (selected as recommended by Reference 14) taken in a sample of the origin-destination zones. Best estimates resulted for home-based trip productions but estimated non-home-based trip productions and all trip attractions appeared to be adequate for planning purposes.

2. Mathematical models developed from current comprehensive O-D or reduced sample data should be of great value in estimating future zonal trip productions and attractions.

3. Only three trip purposes-home-work, home-other, and non-home were found to be practical divisions of all trips for prediction of zonal trip productions and attractions from mathematical models based on comprehensive or reduced sample O-D data.

4. For home-work trip attractions, the number of jobs in a zone was the only important factor. 
5. For home-work trip productions, the number of employed persons per dwelling unit was not found to be a more important factor than persons per dwelling unit.

6. For all trip productions, the number of persons and the number of cars per dwelling unit were found to be very important factors. Other factors of importance for trip productions were distance to the CBD for home-work and home-other trips and area of various land uses and number of jobs for non-home trips.

7. For trip attractions other than the home-work trip, the number of persons per zone, the number of various types of jobs in the zone, and the areas devoted to various land uses were found to be important factors.

8. Travel time factors for distribution of trips by the gravity model were satisfactorily estimated by calibrating the gravity model with trip length frequency data developed from a small sample of home interviews taken in a sample of the $\mathrm{O}-\mathrm{D}$ zones.

9. The travel time factors which were developed varied in value for the different trip purposes for the same travel-time separation.

10. The gravity model using trip productions and attractions and travel time factors developed from a small sample of home interviews taken in a sample of O-D zones distributed trips among all zones to give an adequate reproduction for planning purposes of the trip distribution 
obtained in a comprehensive O-D survey.

11. The gravity model using trip productions and attractions and travel time factors developed from a comprehensive O-D survey distributed trips among all zones to give a good reproduction of the trip distribution obtained in the comprehensive survey. 


\section{RECOMMENDATIONS FOR FURTHER RESEARCH}

It is felt that further research is needed in developing a usable mathematical function for travel time factors. Some recent research conducted in this area is discussed in reference (17).

It is believed that trip production and attraction studies among a number of smaller cities in the same geographical region may well yield similar estimating equations based upon zonal characteristics alone. A brief investigation indicated that Hutchinson production equations when applied to Pittsburg, Kansas, zonal data yielded productions that compared favorably with Pittsburg travel data.

In addition, such studies can be expected to yield information concerning the reasons for the similarities and differences among the equations developed for the rarious cities. Truck trips as well as auto trips should be studied.

If trip productions and attractions can be reliably estimated in this manner, then it would remain necessary only to determine the trip length frequency in order to calibrate a gravity model. If the gravity model research currently being carried out at North Carolina State University indicates that one can, using a small random sample O-D survey, determine satisfactory trip length information, then the Hutchinson data and computer programs developed in this research project should enable one to determine the minimum sampling rate applicable to Hutchinson in a relatively short time. 
LIST OF REFERENCES 


\section{LIST OF REFERENCES}

(1) "The Use of the IBM 7090 Electronic Computer in Calibrating and Testing a Gravity Model for any Specific Urban Area" First draft (unpublished), Interarea Travel Formula Project, Urban Development Branch, Urban Planning Division, Office of Planning, U. S. Department of Commerce, Bureau of Public Roads, April 1963:

(2) Carey, H. C., Principles of Social Science, Philadelphia, J. B. Lippincott and Company, 1858 .

(3) Zipf, G. K., Human Behavior and the Principle of Least Effort, Cambridge, Mass., Addison-Wesley Press, Inc., 1949.

(4) Reilly, W. J., Methods for the Study of Retail Relationships, Austin, University of Texas, Bureau of Business Research, 1929.

(5) Casey, H. J., Jr., "The Law of Retail Gravitation" in Traffic Quarterly, The Eno Foundation for Highway Traffic Control, Vol. IX, No. 3, July 1955.

(6) Voorhees, A. M., "A General Theory of Traffic Movement", Proceedings, Institute of Traffic Engineers, 1955.

(7) Voorhees, A. M., "Forecasting Peak Hours of Travel", Highway Research Board Bulletin 203, 1958.

(8) Davidson, R. G., "Developing a Traffic Model with a Small Sample", Highway Research Board Bulletin 297, 1961.

(9) Wiant, R. H., "A Simplified Method for Forecasting Urban Traffic", Highway Research Board Bulletin 297, 1961.

(10) "1960-1980 Traffic Patterns in Ottumwa", Report, Traffic and Highway Planning Department, Division of Planning, Iowa State Highway Commission in Cooperation with the U. S. Bureau of Public Roads, March 1961.

(11) Voorhees, A. M., "Estimating and Forecasting Travel for Baltimore by Use of a Mathematical Model", Highway Research Board Bulletin 224, 1959. 
(12) Bouchard, R. J., "Sample Gravity Model Distribution", a report (unpublished), Urban Development Branch, Urban Planning Division, Office of Planning, U. S. Department of Commerce, Bureau of Public Roads, June 1962.

(13) "Sixteen-twenty Card Regression Analysis Program (SCRAP), IBM PROGRAM LIBRARY FILE No. 6.0.003, IBM, 425 Park Avenue, New York.

(14) Sosslau, A. B. and G. E. Brokke, "Appraisal of Sample Size Based on Phoenix O-D Survey Data", Highway Research Board Bulletin 253, 1960.

(15) Schultz, E. F., Jr., and J. F. Goggans, "A Systematic Procedure for Determining Potent Independent Variables in Multiple Regression and Discriminant Analysis", Bulletin 336, Agricultural Experiment Station. Auburn University, Auburn, Alabama, November 1961.

(16) "Gravity Model Procedures Used by Lowa Planning Survey", Division of Planning and Research, Region 5, Kansas City, Missouri, U. S. Department of Commerce, Bureau of Public Roads, July 1962.

(17) Dieter, K. H., "Distribution of Work Trips in Toronto", Proceedings of the American Society of Civil Engineers, Journal of the City Planning Division, Vol. 88, No. CP1, August 1962.

\section{GENERAL REFERENCES}

Lynch, J. T., "home Interview Surveys and Related Research Activities", Highway Research Board Bulletin 224, 1959.

Mertz, W. L. and L. B. Hamner, "A Study of Factors Related to Urban Travel", Public Roads, Vol. 29, No. 7, April, 1957.

Sharpe, G. B., W. G. Hansen and L. B. Hamner, "Factors Affecting Trip Generation of Residential Land-use Areas", Highway Research Board Bulletin 203, 1958.

Wiant, R. H., Iowa Highway Commission, "The Traffic Planner's Role", paper presented at Urban Transportation Planning Seminar, Kansas State University, April, 1961.

"Traffic Patterns in Ottumwa - 1960-1980 - A Gravity Model Study", a report by the Traffic and Highway Planning Department, Division of Planning, Iowa State Highway Commission in cooperation with the Bureau of Public Roads. March, 1961. 
Heald, K. L., programming engineer, lowa State Highway Commission, "Discussion of the Iowa Gravity Model Traffic Distribution Program", report, March, 1960.

Lapin, H. S., "Report on Analysis of Urban Work Trips", Highway Research Board Bulletin 224, 1959.

Voorhees, A. M., G. B. Sharpe and J. T. Stegmaier, "Shopping Habits and Travel Patterns", Highway Research Board Special Report 11-B, 1955.

Kudlick, W., E. S. Fisher, and J. A. Vance, "Intermediate and Final Quality Checks in Developing a Traffic Model", a paper presented at the Highway Research Board 42nd Annual Meeting, January 1963.

Harper, B. C. S. and H. M. Edwards, "Generation of Person Trips by Areas Within the CBD" Report No. 9, Queen's University, Kingston, Ontario and Highway Research Board Bulletin 253, 1960.

Pollard, W. S., "Forecasting Traffic with a Modified Growth Factor Procedure", Highway Research Board Bulletin 297, 1961 .

Osofsky, S., California Highway Department Economics, "A Multiple Regression Approach to Forecasting Urban Area Traffic Volumes", paper presented at AASHO Annual Meeting, 1958.

Hall, E. M., "Travel Characteristics of Two San Diego Subdivisions" Highway Research Board Bulletin 203, 1958.

Martin, B. V., F. W. Memmott and A. J. Bone, "Principles and Techniques of Predicting Future Demand for Urban Area Transportation", Research Report No. 38, Massachusetts lnstitute of Technology, Cambridge, Mass., January 1962.

Hansen, W. G., "Evaluation of Gravity Model Trip Distribution Procedures", Highway Research Board Bulletin 347, 1962. 
APPENDIX A 
HUTCHINSON KANSAS

METROPOLITAN AREA TRANSPORTATION STUDY

LAND USE SURVEY

FIELD INSTRUCTIONS AND CODE MANUAL

KANSAS STATE HIGHWAY COMMISSION

\section{INTRODUCTION}

The information will be inventoried and summarized on a census tract, or zone, and block basis. Two tabulating cards will be used for summarizing the data.

Card I will contain the block statistical data.

Card 2 will detail the land uses by area in thousands of square feet.

Card columns 1 to 10 inclusive are identification columns and will be common to both cards.

Card columns 11 to 29 inclusive are block statistical data and will be punched in card 1 only.

Card columns 11 to 29 inclusive will be blank on Card 2 .

Card Col.

$1-2$

$3-4$

5

$6-7$

8

$9-10$
Item

Year of survey

City being studied. Code the project number assigned to the city. (For Hutchinson, this is 95)

Sub-area. Metropolitan area sub-divisions.

Code

Area

$1 \quad$ Inside major city limits

2 Unincorporated

3 Minor city

Tract or zone. From metropolitan area map.

Sub-zone. Code "O" for Hutchinson.

Block number. From metropolitan area map. 


\section{Coding instructions - continued}

\section{LAND USE}

For multi-storied buildings and for single storied buildings with two or more businesses on the ground floor, use a line, not to be coded or punched, to name the building, and enter dimensions and gross area under "Description". This data will be used only for checking total areas of detailed land uses by floors. Inventory the first floor of multi-storied buildings before the basement or upper floors.

Description: Filed - describe the uses of an area or the floor of a building. Enter each use on a separate line.

Card Col. Item

$36-38$ Office coding: Use the land use code in appendix.

$39-40$ "11 Use codes set up for the city's zoning.

\section{BUILDING FIRST FLOOR OR OPEN GROUND}

Field form: First floor of building or open ground

Dimensions: Enter dimensions of each land use

$41-45 \quad$ Enter the calculated area to the nearest 1000 square feet

Note: For business buildings with more than one use on a floor, the total area must equal the calculated gross area shown on the heading line for the building.

\section{BUILDING FLOORS OFF THE GROUND \\ (including basements where applicable)}

Enter a separate line for each use.

Enter dimensions for each use OR percentage of gross floor area.

$41-45$

Area: Code area to nearest 1000 square feet and punch in col. 41-45. Note: Calculated floor area for each use must equal gross floor area. 
Coding instructions - continued

Note 1: Block totals at bottom of column headed "Building 1st Floor, or Open Ground Area" should equal the line headed "Net for other uses".

Note.2: Sum of the 2 total blocks gives total area usage except streets and alleys. 


\section{LAND USES AND CODES}

\section{MAJOR GROUPS}

$0 \quad$ Residential

I Manufacturing

10 - Heavy

11 - Other

2 Retail Trade

3 Wholesale and Warehouse

4 Transportation

5 Construction

6 Personal, Business, Repair Services and Office

7 Government and Utility

8 Other open space - streets, alleys, rivers, lakes, etc.

9 Recreation and Institution

$\underline{\text { Residential (000 series) }}$

000 Vacant land zoned residential

010 Unclassified

020 Single dwelling unit - detached

030 Single dwelling unit - attached

Multiple dwelling units

$0413-19$ units

04220 or more units

050 Rooming and boarding houses

060 Hotels

070 Motels, tourist homes, tourist camps

080 Trailer courts or camps 
Residential (000 series) continued

090 Dormitories, lodging houses on a membership basis

\section{Manufacturing Industries - Heavy ( 100 series)}

101 Mining, quarrying, and other extracting industries

102 Lumber and wood products, except furniture

103 Stone, clay and glass products

104 Metal products

105 Machinery

106 Chemical and allied products

107 Petroleum refining and related industries

108 Paper and allied products

109 Transportation equipment

Manufacturing Industries - Other (110 series)

110 Furniture and fixtures

111 Professional, scientific, and controlling instruments; photographic and optical goods; watches and clocks

112 Textile mill and apparel products

113 Printing, publishing and allied industries

114 Food and kindred products

115 Rubber and miscellaneous products

116 Tobacco products

117 Leather and leather products

118 Miscellaneous manufacturing industries

119 Vacant land zoned industrial 
$\underline{\text { Retail Trade (200 series) }}$

200 Vacant land zoned commercial

210 Unclassified retail outlets

220 Super food markets

221 Other food establishments

230 Drug stores, eating and drinking establishments

240 Department store and general merchandise stores

250 Apparel and accessories stores

260 Furniture, home furnishings and appliance stores

270 Motor vehicle and vehicle accessories stores; boats and marine equipment; farm equipment. (Sales and Service)

280 Gasoline service stations

290 Lumber and building materials and hardware stores

Wholesale and Warehouse ( 300 series)
$\begin{array}{cl}300 & \text { Unclassified } \\ 320 & \text { Wholesalers with stock } \\ 330 & \text { Warehousing and storage }\end{array}$

Transportation (400 series)

$400 \quad$ Unclassified

$410 \quad$ Railroad terminals

420 Railroad yards

430 Local and interurban mass transportation, school buses and taxicabs

440 Air transportation

450 Motor freight transportation

460 Other transportation (water and pipeline) 
Construction ( 500 series)

$500 \quad$ Unclassified

510 General highway and heavy construction contractors with storage yards for construction and maintenance equipment and oil field construction equipment.

520 General building contractors with storage yards for construction and maintenance equipment.

530 General wrecking concerns and storage yards

540 Special trades contractors (electrical, plumbing, etc.)

550 Buildings (all types) under construction

Personal Business, Repair Services and Offices (600 series)

600 Miscellaneous repair and service

610 Personal services

620 Business services

630 Parking services

640 Automobile repair and service

650 Unclassified offices

660 Financial, insurance, and real estate - offices

670 Medical and health services -

680 Other professional services -

11

Government and Utility ( 700 series)

700 Communication

710 Utilities (electric, gas and sanitary service)

720 Post Offices and government, operational

730 Government, administrative and legal

$740 \quad$ Military 
APPENDIX B 


\section{DESCRIPTIONS OF COMPUTER PROGRAMS} WRITTEN FOR THIS RESEARCH PROJECT

TITLE: SAMPLE SELECTOR FOR TRIP PRODUCTION DECK No. $110-27 \mathrm{GM}$

Prog. 110-27GM prepares cards in proper input form for "SCRAP"

Regression Analysis Program for use in developing estimating equations for trip productions. Input is $O-D$ survey Card $I$ and Card 2 in order by zone.

TITLE: HOME BASED TRIP ATTRACTIONS

DECK No. 110-04GM

Prog. 110-04GM expands the home based trip attraction data in O-D survey Card 2. Input cards are sorted onEAM. Output is cards.

TITLE: NON-HOME BASED PRODUCTIONS AND ATTRACTIONS DECK No. 110-06GM

Prog. 110-06 GM expands the non-home based trip production and attraction data in $O-D$ survey Card 2. Trip productions are expanded manually and the input cards are sorted on EAM.

Output is cards.

TITLE: O-D SAMPLE RATE REDUCER

DECK No. $110-07 \mathrm{GM}$

Prog. 110-07GM utilizes O-D survey Card 1 and Card 2 in selecting the desired per cent of the original sample size.

TITLE: TRIP LENGTH FREQUENCY

DECK No. II0-10GM

Prog. 110-10GM utilizes the output from the Missouri Tree Building Program for zone to zone movements and accumulates the trips by time interval (up to $40 \mathrm{~min}$.) and trip purpose. Input may be either the O-D survey Card 1 and Card 2 or the output Card 1 from the Gravity Model (Prog. 110-05GM) Output is cards.

TITLE: TRIP LENGTH FREQUENCY CONDENSER DECK No. II0-15GM

Prog. 110-15GM utilizes the output cards of Prog. II0-10GM as input and computes and types out by trip purpose the per cent trips by time interval (up to 40 minutes), the total number of trips, the vehicle minutes of travel and the average trip length in minutes. 
TITLE: GRAVITY MODEL DISTRIBUTION

DECK No. $110-05 \mathrm{GM}$

Prog. 110-05GM distributes the input trip productions and attractions to the zones and lists the observed and calculated values of productions and attractions by zone. Input consists of the total number of zones, inter-zonal travel times, $\mathrm{K}$-Factors (not used), productions, attractions and terminal times, and travel time factors.

\section{TITLE: SCREENLINES - GM}

DECK No. $110-20 \mathrm{GM}$

Prog. 110-20GM tabulates the number of trips crossing a screenline for a single gravity model purpose. Input consists of the output Card 1 from the Gravity Model (Prog. 110-05GM) and a deck containing the zones on each side of the screenline. Output is cards.

TITLE: SCREENLINES - O-D

DECK No. $110-21 \mathrm{GM}$

Prog. 110-21GM tabulates the number of trips crossing a screenline for each of up to five (5) general purposes and total trips. Input consists of the O-D survey Card 2. Card 1 may be included but is overlooked by the computer. Output is cards.

TITLE: VEHICLE-MILES O-D

DECK No. $110-40$ GM

Prog. 110-40GM computes to 0.1 mile the "L" distance from the centroid of the zone of origin to the centroid of the zone of destination. Input consists of the $\mathrm{x}$ and $\mathrm{y}$ coordinates of each zone centroid and the O-D summary cards from Prog. 110-102 GM. Vehicle miles of travel are typed out.

TITLE: VEHICLE MILES GM

DECK No. $110-41 \mathrm{GM}$

Prog. 110-41GM computes to 0.1 mile the " $L$ " distance from the centroid of the zone of production to the centroid of the zone of attraction. Input consists of the $s$ and $y$ coordinates of each zone centroid and the output Card 1 from Prog. $110-05$ GM.

TITLE: POLYNOMIAL OF BEST FIT DECK No. $110-30 \mathrm{GM}$

Prog. 110-30GM computes the desired degree of polynomial to best fit a given set of points ( $x-y$ coordinates). The co-efficient of each term and the RMS error are typed out and the $x-y$ coordinates, input and computed, are punched out. 
TITLE: EQUATION EVALUATION

DECK No. $110-35 \mathrm{GM}$

Prog. 110-35GM, utilizing the coefficients from the Multiple Regression Analysis "SCRAP" and the values of the variables in the equation, solves the equation for the dependent variable. Output is cards.

TITLE: REFORMAT O-D VOLUMES (HIGH ZONE TO LOW ZONE) DECK No. I10-50GM

Prog. 110-50GM reformats the O-D survey Card 2 so that all trips go from high numbered zones to low numbered zones, resulting in two cards for each combination, $i . e$, the original trips from the high zone to the low zone plus the reverse trips between the same zones with the trip ends interchanged. Output is cards.

\section{TITLE: COMBINE O-D VOLUMES}

DECK No. $110-102 \mathrm{GM}$

Prog. 110-102GM combines the two output cards from Prog. 110$50 \mathrm{GM}$ into one, with all trips from high to low numbered zones. Output is cards.

\section{TITLE: PAIR OD-GM VOLUMES}

DECK No. $110-103 \mathrm{GM}$

Prog. 110-103GM requires as input the reformatted and combined O-D data output from Prog. 110-102GM and the output Card 1 from Prog. 110-05GM. This program combines the gravity model volume to two-way and pairs the corresponding O-D and GM two-way volumes between each pair of zones. Output is cards

TITLE: COMPARISON ANALYSIS

DECK No. 110-104GM

Prog. 110-104GM, using the paired volumes from Prog. 110-103GM, accumulates by volume groups a table of differences by differences groups. It then computes for each volume group the frequency of differences, the mean difference, the standard deviation of the differences, the RMS error, the per cent RMS error and the total number of O-D and GM trips. Output is cards.

TITLE: CARD CONVERSION (GM TO TRAFFIC ASSIGNMENT) DECK No. 110-110GM

Prog. 110-110GM converts the output Card I from Prog. 110-05GM to input format for the Missouri Traffic Assignment Program.

Output is cards. 
TITLE: STATISTICAL TEST OF REGRESSION ESTIMATES DECK No. $110-106 \mathrm{GM}$

Prog. 110-106GM computes and types out RMS error and per cent RMS error of estimated productions or attractions versul O-D productions or attractions.

The following programs were used but were not written for this project:

SCRAP, Sixteen-twenty Card Regression Analysis Program, IBM Program Library File No. 6.0.003.

A multiple regression analysis program capable of handling a maximum of 23 variables and was used in the developmen $\dot{t}$ of estimating equations.

The battery of programs, originally written by the Missouri Highway Commission, for traffic assignment was utilized in the determination of "time trees" for the Gravity Model Districution (Prog. 110-05GMO) and Trip Length Frequency (Prog. 110-10GM) Programs. 
VITA 


\section{VITA}

Bob L. Smith was born January 26, 1926 in Topeka, Kansas. He received his primary education at a country school near Emporia, Kansas, and was graduated from Emporia High School in 1943.

He entered Kansas State University in 1943 and spent one semester there. He completed a year's work at Kansas State Teachers College, Pittsburg, Kansas in 1944 in a naval training program. After returning from the navy as an ensign, USNR, in 1946, he entered Kansas State University again, and received his B.S.C.E. degree (with honor) in 1948. He received his M. S. degree in 1953 from Kansas State University.

In 1948 , he was a student instructor in the Department of Applied Mechanics at Kansas State, and in 1949 he became an instructor in that department. Since 1950, he has been a member of the Civil Engineering faculty at Kansas State, and presently holds the rank of Associate Professor. In 1959, he was granted a National Science Faculty Fellowship and completed the coursework required for the Ph. D. in the School of Civil Engineering at Purdue University. He is an associate member of the American Society of Civil Engineers, a registered professional engineer in Kansas, a member of the National Society of Professional Engineers, a member of the Kansas Engineering Society, and a member of the American Society for Engineering Education. He is a member of the following honorary organizations: Sigma Tau, Kappa Mu Epsilon, and Phi Kappa Phi. 

